$$
\begin{aligned}
& \text { UNIVERSIDADE DE SÃO PAULO } \\
& \text { INSTITUTO DE GEOCIÊNCIAS }
\end{aligned}
$$

\title{
GEOCRONOLOGIA Ar-Ar E GEOQUÍMICA ISOTÓPICA DE ROCHAS DAS ILHAS DE ANO-BOM, SÃO TOMÉ E PRÍNCIPE DA LINHA VULCÂNICA DOS CAMARÕES
}

\author{
José Manuel dos Ramos Lopes
}

Orientador: Prof. Dr. Umberto Giuseppe Cordani

\section{Dissertação de Mestrado}

Programa de Pós-Graduação em Geoquímica e Geotectônica 



$$
\begin{aligned}
& \text { UNIVERSIDADE DE SÃO PAULO } \\
& \text { INSTITUTO DE GEOCIÊNCIAS }
\end{aligned}
$$

Geocronologia Ar-Ar e Geoquímica Isotópica de rochas das Ilhas de Ano-Bom, São Tomé e Príncipe da Linha Vulcânica dos Camarões

\section{JOSÉ MANUEL DOS RAMOS LOPES}

Dissertação apresentada ao Instituto de Geociências da Universidade de São Paulo para a obtenção do título de Mestre em Geociências

Área de concentração: Geoquímica e Geotectônica

Orientador: Prof. Dr. Umberto Giuseppe Cordani

SÃO PAULO 
Autorizo a reprodução e divulgação total ou parcial deste trabalho, por qualquer meio convencional ou eletrônico, para fins de estudo e pesquisa, desde que citada a fonte.

Serviço de Biblioteca e Documentação do IGc/USP

Ficha catalográfica gerada automaticamente com dados fornecidos pelo(a) autor(a) via programa desenvolvido pela Seção Técnica de Informática do ICMC/USP

Bibliotecários responsáveis pela estrutura de catalogação da publicação: Sonia Regina Yole Guerra - CRB-8/4208 | Anderson de Santana - CRB-8/6658

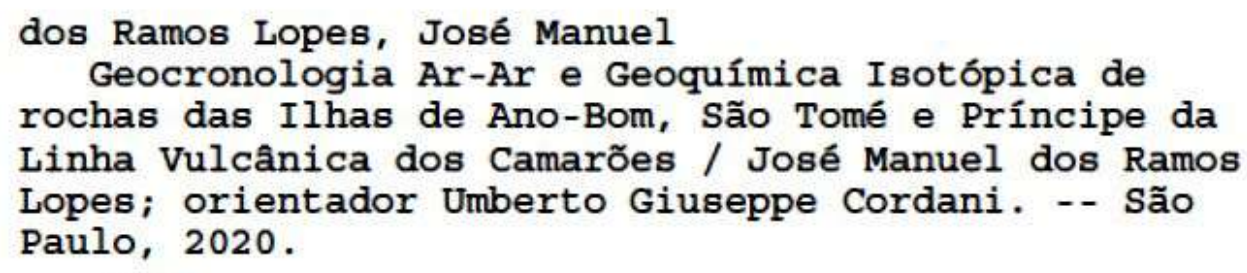

1. Geocronologia. 2. Geoquímica. 3. Ano-Bom. 4. são Tomé. 5. Príncipe. I. Giuseppe Cordani, Umberto, orient. II. Título. 




$$
\begin{aligned}
& \text { UNIVERSIDADE DE SÃO PAULO } \\
& \text { INSTITUTO DE GEOCIÊNCIAS }
\end{aligned}
$$

Geocronologia Ar-Ar e Geoquímica Isotópica de Rochas das Ilhas de Ano-Bom, São Tomé e Príncipe da Linha Vulcânica dos Camarões

\section{JOSÉ MANUEL DOS RAMOS LOPES}

Orientador: Prof. Dr. Umberto Giuseppe Cordani

Dissertação de Mestrado

№ 859

COMISSÃO JULGADORA

Dr. Umberto Giuseppe Cordani

Dr. Valdecir Assis Janasi

Dr. João Manuel Lima da Silva Mata

SÃO PAULO

2020 
Trabalho dedicado à família Dias dos Ramos Lopes,

Ester, Giovanna, Daví e Maria Alice, meus amores.

Gratidão pela energia, sorriso, compreensão e paixão.

Meu coração fora do peito e motivo pelo qual lutarei. 


\section{Agradecimentos}

Este trabalho é fruto de um sonho coletivo, no qual fui incumbido de o tornar real. As espectativas foram enormes, a caminhada longa e o final dramático. Num ano que muito prometeu, mas o inesperado aconteceu, não excluindo ninguém e deixando cicatrizes em todos que vivenciaram esta pandemia. No entanto, há muito que agradecer à todos que me deram suporte nesta segunda jornada no Brasil. Gratidão ao Brasil e São Tomé e Príncipe pela cooperação, ao IGc-USP pela oportunidade de continuar enriquecendo meus conhecimentos, ao CNPq por financiar a pesquisa (processo 190347/2017-1), ao CPGeo por financiar o trabalho de campo nas ilhas e aos técnicos dos laboratórios do IGc-USP pelo apoio.

Deixo expressa minha gratidão ao amigo e professor Dr Umberto Cordani, que foi mais do que um orientador, foi como pai nesses 24 meses, dando suporte e guiando nos trilhos da geologia. À Profa. Dra Maria Helena Hollanda, pelo suporte durante todo o percurso, principalmente na contribuição na conclusão do estudo da geocronologia, e ao Prof. Dr Rogério Azzone pela inestimável contribuição dos seus conhecimentos na geoquímica e na conclusão da pesquisa, meus agradecimentos.

À Embaixada de São Tomé e Príncipe na Guiné Equatorial, em especial à Sra Embaixadora Ângela Pinheiro, Primeiro Secretário Hermansson Maquengo, ao Quaresma e à Sra Joaquina pela amabilidade e suporte logístico e institucional. Ao Governo da Guiné Equatorial, à Universidad Nacional da Guinea Ecuatorial pelo apoio institucional, e aos meus grandes amigos Silvano e Ching pelo acolhimento e companheirismo na llha de Ano-Bom, deixo registrado meu sentido agradecimento.

Ao Belinazir Espírito Santo, Euridiney Pinto, Deonel Mandu e Djoseph Mendes, que me ensinaram o verdadeiro sentido de amizade e companheirismo, tornando-se irmãos, que levarei para vida, deixo afiançada a minha eterna gratidão. À Rafaela Gengo pela amizade e apoio doado até o último segundo, ao Lucas Lino e Alana Dantas pela partilha de conhecimento durante a dissertação, só tenho a agradecer. Ao Thyago Silva, obrigado por tudo irmão "zircon is forever".

O mais importante dos agradecimentos vai para minha Mãe e Rainha, Maria Teresa Barros, meu exemplo de vida, a quem expresso meu tamanho amor. $O$ amor e dedicação, transmitindo sabedoria e luz, envoltas em turbilhão de adversidades, nos fortaleceu. Aos meus irmãos, Eliseu e Heidy, agradeço por cuidarem de mim desde a tenra idade, pela amizade, força, encorajamento ao longo da estrada da vida. O nosso amor é fruto da simplicidade, educação e dedicação matriarcal. 


\section{Resumo}

A litosfera oceânica Atlântica, no Golfo da Guiné, comporta três ilhas vulcânicas, Ano-Bom, São Tomé e Príncipe, como partes integrantes da extensa Linha Vulcânica dos Camarões, que se adentra ao continente africano, albergando inúmeros centros vulcânicos, interceptada por uma zona de transição intermediária. O fraco conhecimento geólogico que se tem das ilhas do Golfo da Guiné, a torna região central da presente pesquisa.

O presente trabalho comporta uma série de resultados petrográficos, geoquímicos e geocronológicos inéditos, que complementam os muitos dados préexistentes, que possibilitaram a caracterização dos litotipos das ilhas, melhorar as idades radiométricas, e sugerir alguma ideia sobre tipo de magmas precursores envolvidos na geração dessas ilhas.

No caso da petrografia e da geoquímica das rochas existentes, houve no geral, a confirmação em relação ao que já se conhecia sobre as variedades máficas e félsicas. Há rochas primitivas básicas e ultrabásicas, bem como termos intermediários e mais evoluídos. Rochas máficas incluem essencialmente olivina, clinopiroxênio, plagioclásio e opacos, enquanto as rochas félsicas comportam clinopiroxênio, k-feldspato, anfibólio e feldspatoide. A geoquímica de rocha total revela duas séries magmáticas, que evoluíram de modo distinto. As duas séries alcalinas, com diferentes gráus de saturação em sílica, em que ambas englobam rochas das três ilhas vulcânicas, tal como rochas primitivas, picro-basaltos, basaltos, basanitos, e rochas mais evoluídas, como fonotefritos, traquiandesitos, fonolitos e traquitos. A relação $\mathrm{Sr}-\mathrm{Nd}$ indica que as fontes mantélicas dos magmas, nas três ilhas são contíguas ao componente HIMU. O sistema isotópico de $\mathrm{Sr}-\mathrm{Nd}-\mathrm{Pb}$ revela fontes distintas, em que as Ilhas de São Tomé e Príncipe são caracterizadas pelo FOZO, enquanto Ano-Bom apresenta característica empobrecidas em chumbo.

A geocronologia $\mathrm{Ar}-\mathrm{Ar}$ associada às demais datações radiométricas das ilhas mostram que a llha do Príncipe (31 Ma) é a mais antiga, seguida de São Tomé (14.44 Ma) e Ano-Bom (5.82 Ma) como a mais recente. Registros do vulcanismo recentes, entre $1.35 \mathrm{Ma}$ e $200 \mathrm{mil}$ anos, são observadas nas ilhas de Ano-Bom e São Tomé. Pelas idades expostas, a llha do Príncipe registrou sua última atividade magmática em $3.5 \mathrm{Ma}$.

Palavras-chave: Geocronologia, Geoquímica, São Tomé, Príncipe, Ano-Bom. 


\begin{abstract}
The Atlantic oceanic lithosphere, in Gulf of Guinea, comprises three volcanic islands, Ano-Bom, São Tomé and Príncipe, as part of the extensive Volcanic Line of Cameroon, which enters the African continent housing numerous volcanic centers, intersected by an intermediate transition zone. The weak geological knowledge of the islands in the Gulf of Guinea makes it the central region of the current study.

The current study comprises a series of new petrographic, geochemical and geochronological data, which complement many pre-existing data, enabling the characterization of the lithotypes of the islands, improving radiometric ages, and suggesting some idea about the type of precursor magmas involved in the generation of these islands.
\end{abstract}

In the case of petrography and geochemistry of the existing rocks, there was, in general, confirmation in relation to what was already known about mafic and felsic varieties. There are basic and ultrabasic primitive rocks, as well as intermediate and more evolved terms. Mafic rocks essentially include olivine, clinopyroxene, plagioclase and opaques, while felsic rocks contain clinopyroxene, k-feldspar, amphibole and foides. Total rock geochemistry reveals two magmatic series, which evolved in a different way. The two alkaline series, with different degrees of saturation in silica, comprise rocks from the three volcanic islands, such as primitive rocks, picro-basalts, basalts, basanites, and also more advanced ones, such as phonotefrites, trachyandesites, phonolites and trachytes. The Sr-Nd relationship indicates that the magmatic mantle sources on the three islands are contiguous to the HIMU component. The Sr-Nd-Pb isotopic system reveals different sources, in with the São Tomé and Príncipe are characterized by the FOZO, while Ano-Bom presents lead-depletion characteristics.

The Ar-Ar geochronology, associated with the other radiometric dates of the islands, show that Príncipe Island (31 Ma) is the oldest, followed by São Tomé (14.44 Ma) and Ano-Bom (5.82 Ma) as the most recent. Recent volcanic records, between 1.35 Ma and 200 thousand years, are observed in the islands of Ano-Bom and São Tomé. The Island of Príncipe registers its last magmatic activity at 3.5 Ma.

Keywords: Geochronology, Geochemistry, São Tomé, Príncipe, Ano-Bom. 


\section{SUMÁRIO}

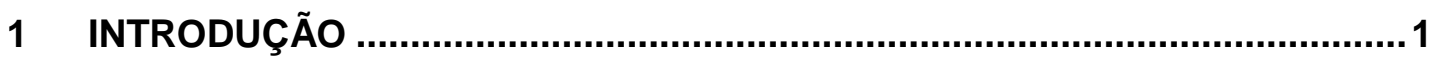

2 GENERALIDADES SOBRE A LINHA VULCÂNICA DOS CAMARÕES ............

2.1 CONTEXTO TECTÔNICO DA LINHA VULCÂNICA DOS CAMARÕES .............................. 5

2.2 CONTEXTO PETROGRÁFICO DA LINHA VULCÂNICA DOS CAMARÕES ......................... 8

2.3 CONTEXTO GEOQUÍMICO DA LINHA VULCÂNICA DOS CAMARÕES............................

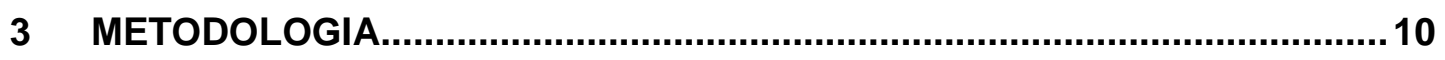

3.1 RECONHECIMENTO GEOLÓGICO E COLETA DE AMOSTRAS ................................. 10

3.2 PREPARAÇÃO DE LÂMINAS DELGADAS DE ROCHA........................................... 12

3.3 PREPARAÇÃO DE AMOSTRAS PARA ANÁLISE DE ROCHA TOTAL ............................... 12

3.4 ESTUDO DE GEOQUÍMICA ELEMENTAL (ROCHA TOTAL) ..................................... 13

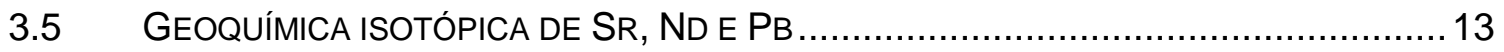

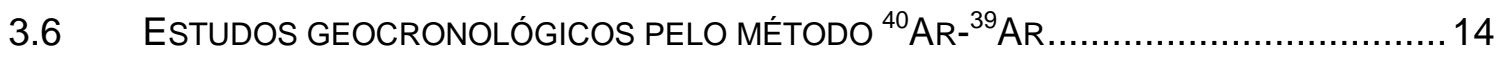

4 GEOLOGIA DAS ILHAS DO GOLFO DA GUINÉ ...................................... 15

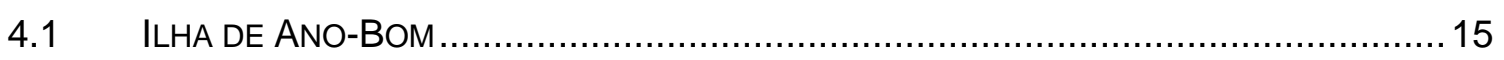

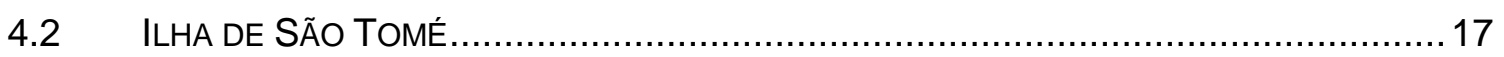

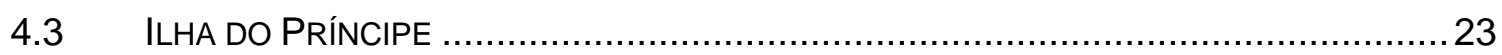

$5 \quad$ RESULTADOS E DISCUSSÕES ...........................................................2

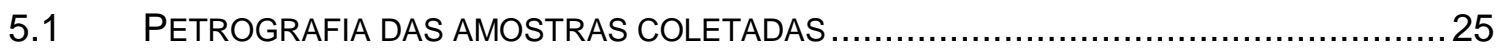

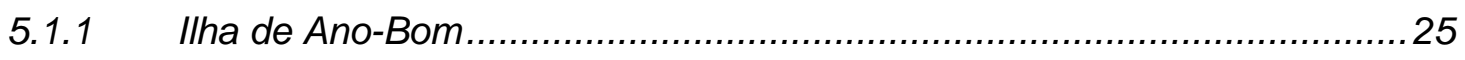

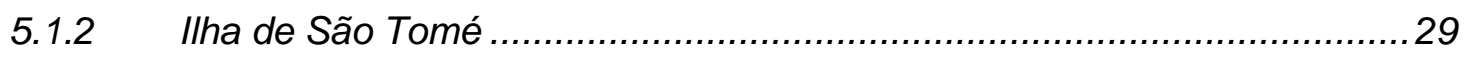

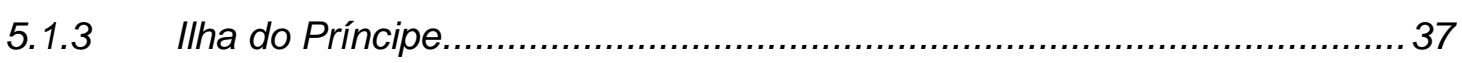

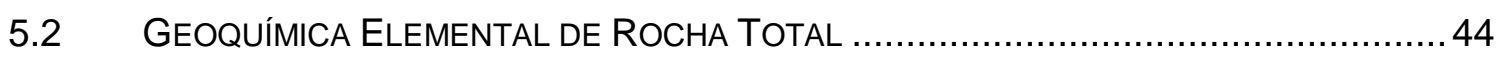

5.2.1 Nomenclatura e Classificação de Rochas............................................... 44

5.2.2 Elementos Maiores e Menores ...................................................... 47

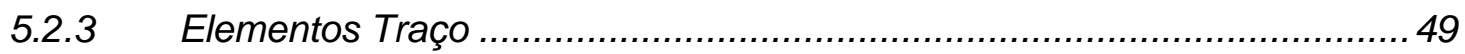

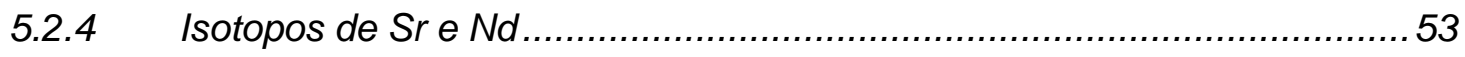

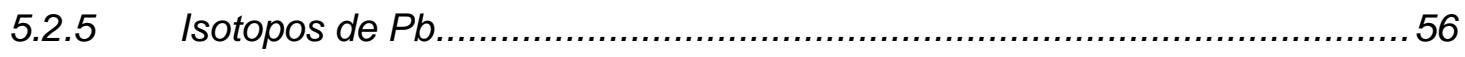

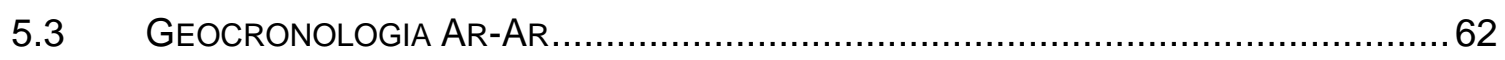

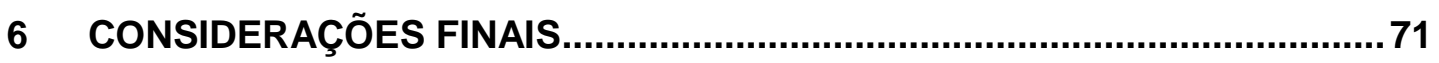

7 REFERÊNCIAS BIBLIOGRÁFICAS........................................................75 


\section{LISTA DE FIGURAS}

FIGURA 1: LINHA VULCÂNICA DOS CAMARÕES, INDICANDO SEUS PRINCIPAIS CENTROS VULCÂNICOS, COM ÊNFASE AO SETOR OCEÂNICO (ÁREA DE ESTUDO). MODIFICADO DE FITTON AND DUNLOP (1985); MARZOLI ET AL. (2000) E NGONGANG ET AL. (2015).

FiguRA 2: REPRESENTAÇÃO DA LINHA VULCÂNICA DOS CAMARÕES EM FORMATO DE LEQUE.

MODIFICADO DE NJOME AND DE WIT (2014). 7

FiguRA 3:MAPA GEOLÓGICO E LOCALIZAÇÃO DE AMOSTRAS COLETAS. AdAPTADO DE CORNEN AND MAURY (1980).

FIGURA 4: MAPA GEOLÓGICO E LOCALIZAÇÃO DE PONTOS DE COLETA EM SÃo TOMÉ (CALDEIRA, 2006). OS PONTOS AZUIS REPRESENTAM AMOSTRAS COLETADAS PARA ESSA DISSERTAÇÃO E OS VERMELHOS, AMOSTRAS DA MONOGRAFIA (LOPES, 2010). 20

FIGURA 5: ESBOÇO GEOLÓGICO E LOCALIZAÇÃO DOS PONTOS AMOSTRAIS DA ILHA DO PRÍNCIPE. ADAPTADO DE NEIVA (1956B)..... 24

FIGURA 6: FOTOMICROGRAFIA DOS LITOTIPOS DA ILHA DE ANO- BOM. 28

FIGURA 7: FOTOMICROGRAFIA DOS LITOTIPOS DA ILHA DE SÃO TOMÉ 36

FIGURA 8: FOTOMICROGRAFIA DOS LITOTIPOS DA ILHA DO PRÍNCIPE. 42

FIGURA 9: DIAGRAMA DE CLASSIFICAÇÃO DE ROCHAS VULCÂNICAS DE LE BAS ET AL. (1986). .... 46 FIGURA 10: Diagramas dE HARKER dE VARIAÇÃO DE ÓXIDOS DE ELEMENTOS MAIORES E MENORES, USANDO MGO COMO ÍNDICE DE DIFERENCIAÇÃO.

FIguRA 11: Diagramas dE HARKER dE VARIAÇÃO DE ELEMENTOS TRAÇO, TENDO MGO COMO ÍNDICE DE DIFERENCIAÇÃO. 51

FIGURA 12: DIAGRAMA DE REPRESENTAÇÃO DE RAZÕES ISOTÓPICAS DE SR E ND. ADAPTADO LEE ET AL. (1994); YANG ET AL. (2014) E ASAAH ET AL. (2020). HIMU= HIGH- $\mu$ MANTLE, EM I= ENRICHED MantLe tYPe I, EM II= EnRICHEd MantLe tYPe II E DMM= Depleted MORB MANTLE, FOZO= Focal ZONE. AB= ANO-BOM, ST= SÃO TOMÉ, P= PRÍNCIPE. 55

FIGURA 13: DIAGRAMA DE VARIAÇÃO ISOTÓPICA DE PB DAS LAVAS DAS ILHAS DE ANO-BOM, SÃO Tomé E Príncipe, MOdificado de LeE ET AL. (1994); Stracke ET AL. (2005); E YANG ET AL. (2014). ST=SÃO TOMÉ, P=PRínCIPE; AB=ANO-BOM. $A=$ DIAGRAMA dE VARIAÇÃO ISOTÓPICA DE ${ }^{206} \mathrm{~PB} /{ }^{204} \mathrm{~PB}$ VERSUS ${ }^{207} \mathrm{~PB} /{ }^{204} \mathrm{~PB} ; \mathrm{B}=$ DIAGRAMA DE VARIAÇÃO ISOTÓPICA DE ${ }^{206} \mathrm{~PB} /{ }^{204} \mathrm{~PB}$ VERSUS ${ }^{208} \mathrm{~PB} /{ }^{204} \mathrm{~PB}$.

FIGURA 14: DiAGRAMA DE VARIAÇÃO ISOTÓPICA DE PB DAS LAVAS DAS ILHAS DE ANO-BOM, SÃO Tomé e Príncipe, modificado de LeE ET AL. (1994); StRacke ET AL. (2005); E YANG ET AL. (2014). ST=SÃO TOMÉ, P=PRínCIPE; $A B=A N O-B O M . ~ A=$ DIAGRAMA de VARIAÇÃO ISOTÓPICA DE ${ }^{206} \mathrm{~PB} /{ }^{204} \mathrm{~PB}$ VERSUS ${ }^{87} \mathrm{SR} /{ }^{86} \mathrm{SR} ; \mathrm{B}=$ DIAGRAMA DE VARIAÇÃO ISOTÓPICA DE ${ }^{206} \mathrm{~PB} /{ }^{204} \mathrm{~PB}$ VERSUS ${ }^{143} \mathrm{ND} /{ }^{144} \mathrm{ND}$. 60 
FIGURA 15: ESPECTROS DE AQUECIMENTO GRADUAL E ISÓCRONAS NORMAIS, PELO MÉTODO ${ }^{40} \mathrm{AR} /{ }^{39} \mathrm{AR}$.

FIGURA 16: ESPECTROS DE AQUECIMENTO GRADUAL E ISÓCRONAS NORMAIS, PELO MÉTODO ${ }^{40} \mathrm{AR} /{ }^{39} \mathrm{AR}$. 68

FIGURA 17: ESPECTROS DE AQUECIMENTO GRADUAL E ISÓCRONAS NORMAIS, PELO MÉTODO ${ }^{40} \mathrm{AR} /{ }^{39} \mathrm{AR}$. 69

FIGURA 18: HISTOGRAMA DO VULCANISMO DAS ILHAS DO SETOR OCEÂNICO DA LINHA VULCÂNICA DOS CAMARÕES. .73

\section{Lista de Tabelas}

TAbela 1: Relação das amostras coletadas em CAMPo PARA DEVIDOS estudos ANALÍTICOS. .11

TABela 2: DataÇões RADIOMÉtRicas dE ROCHAS DA ILHA DE ANO-BOM (LVC). 16

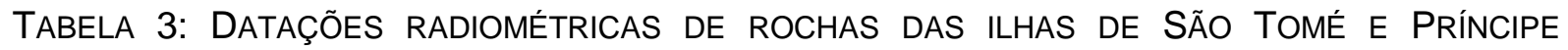
(LVC) .22

TABela 8: Resultados isotópicos DE SR E ND DA AMOstras ANALISADAS...... .54

TABela 9: Resultados isotópicos DE PB DAS amostras ANALISADAS .56

TABela 10: DATAÇÕES RADIOMÉtRICAS AR-AR DAS ILHAS DE ANO-BOM, SÃO TOMÉ E PRÍNCIPE.

\section{APÊNDICES}

TABELA 4: ANÁLISES MODAIS DE ROCHAS DA ILHA DE ANO-BOM (EM APÊNDICE A).

TABELA 5: ANÁlISES MODAIS DE ROCHAS DA ILHA DE SÃO TOMÉ (EM APÊNDICE A).

TABELA 6: ANÁLISES MODAIS DE ROCHAS DA ILHA DO PRÍNCIPE (EM APÊNDICE A).

\section{ANEXOS}

ANEXO 1 - TABELA 7: RESULTADOS DE ANÁLISES GEOQUÍMICASPOR FRX.

ANEXO 2 - TABELA 8A: DADOS DE ISÓTOPOS DE SR E ND DAS ILHAS.

ANEXO 3 - TABELA 9A: DADOS DE ISÓTOPOS DE PB DAS ILHAS. 


\section{INTRODUÇÃO}

A Linha Vulcânica dos Camarões (LVC) é uma gigantesca zona de cisalhamento vulcânico-plutônica alcalina formada por um conjunto de cadeias vulcânicas com extensão de aproximadamente $1700 \mathrm{~km}$, que se adentra ao continente africano com direção SW-NE, desde a ilha de Ano-Bom até o planalto de Kapsiki (Camarões), com ramificações na direção norte para o planalto de Biu (Nigéria) e leste para o planalto de Adamawa (Camarões). Este alinhamento vulcânico compreende porções da litosfera oceânica e continental, com uma zona de transição intermediária, entre a llha de Bioko e Monte Camarões (figura 1).

Diversos registros de manifestações magmáticas aparecem ao longo da LVC, havendo variações quanto à evolução e diferenciação dos magmas. A origem e significação tectono-magmática da LVC vem sendo discutida há décadas (Fitton and Dunlop, 1985; Lee et al., 1994; Njome and de Wit, 2014; dentre outros), através de debates, ainda inconclusivos. Em especial, há carência de conhecimento da geologia das ilhas do setor oceânico, região privilegiada para permitir a comparação entre vulcanismo intraplaca oceânico e continental.

Neste trabalho serão consideradas as ilhas de Ano-Bom, São Tomé e Príncipe, que representam a parte emergente de edifícios vulcânicos assentados na plataforma submarina da crosta oceânica do Golfo da Guiné. Suas rochas são predominantemente de natureza basáltica, apresentando também termos mais evoluídos, de composição fonolítica e traquítica. As idades radiométricas obtidas até o presente nessas ilhas são jovens, normalmente abaixo de $10 \mathrm{Ma}$. A idade máxima pertence a uma rocha da ilha do Príncipe com $31 \mathrm{Ma}$. Como a ilha de São Tomé é a que apresenta conhecimento geológico, petrográfico e geoquímico muito maior do que $o$ das outras duas ilhas, nessa pesquisa será dada maior ênfase às ilhas do Príncipe e Ano-Bom, para um maior equilíbrio no conhecimento do vulcanismo no Golfo da Guiné.

A presente pesquisa objetiva conhecer as principais características composicionais dos litotipos presentes, melhorar o conhecimento geocronológico, bem como obter dados sobre a origem dos magmas precursores envolvidos na geração das três ilhas do setor oceânico da LVC. A ilha de São Tomé tem sido alvo de estudos do autor desde a época de Graduação em Geologia, obtida em 2010 na mesma Universidade de São Paulo. Essa ilha foi tema de sua Monografia de 
Trabalho de Formatura, em que houve contribuições importantes. Complementando trabalhos desenvolvidos por Rita Caldeira e colaboradores, seus resultados foram apresentados na Goldschmidt Mineralogical Magazine (Lopes et al., 2011). As análises de $\mathrm{Sr}$ e $\mathrm{Nd}$ em basaltos, basanitos, fonolitos e traquitos, obtidas nos diferentes complexos vulcânicos da llha de São Tomé, serão utilizados nesse trabalho como auxílio na interpretação do capítulo de geoquímica isotópica.

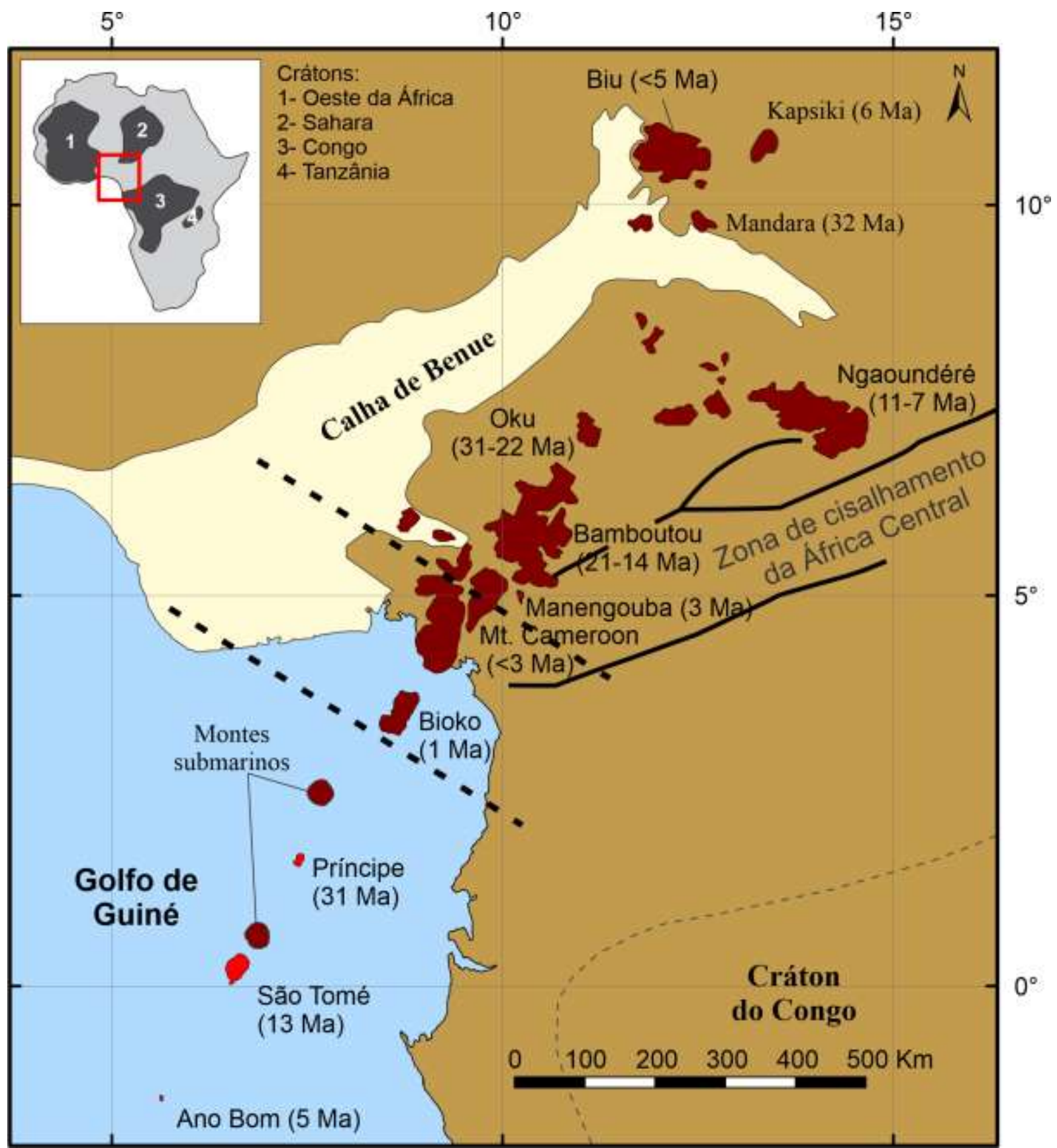

Figura 1: Linha Vulcânica dos Camarões, indicando seus principais centros vulcânicos, com ênfase ao setor oceânico (área de estudo). Modificado de Fitton and Dunlop (1985); Marzoli et al. (2000) e Ngongang et al. (2015). 


\section{GENERALIDADES SOBRE A LINHA VULCÂNICA DOS CAMARÕES}

A ilha de Ano-Bom localiza-se à $1^{\circ} 24^{\prime} \mathrm{S}-1^{\circ} 28^{\prime} \mathrm{S}$ e $5^{\circ} 36^{\prime} \mathrm{E}-5^{\circ} 38^{\prime} \mathrm{E}$, e dista $190 \mathrm{~km}$ NNE da llha de São Tomé e $360 \mathrm{~km}$ da costa ociedental da África. Ela consta como uma das sete províncias da Guiné Equatorial, com um comprimento de aproximadamente $6,4 \mathrm{~km}$ por 3,2 km de largura, e sua área superficial emersa totaliza $17,5 \mathrm{~km}^{2}$ (Velayos et al., 2014).

A ilha de São Tomé localiza-se entre as latitudes $0^{\circ} 24^{\prime} 40^{\prime \prime} \mathrm{N}-0^{\circ} 00^{\prime} 02^{\prime \prime} \mathrm{S}$ e longitude 6 6 $28^{\prime} 19^{\prime \prime} \mathrm{E}-6^{\circ} 45^{\prime} 00^{\prime \prime} \mathrm{E}$, e dista $150 \mathrm{~km}$ a SSW da ilha do Príncipe e $300 \mathrm{~km}$ do continente africano, possuindo uma área aproximada de $859 \mathrm{~km}^{2}$, com $48 \mathrm{~km}$ de eixo maior e $34 \mathrm{~km}$ de eixo menor, sendo que a linha do Equador atravessa o llhéu das Rolas situado a sul da ilha (Munhá et al., 2007).

A ilha do Príncipe localiza-se à $1^{\circ} 32^{\prime} \mathrm{N}-1^{\circ} 43^{\prime} \mathrm{N}$ e $7^{\circ} 20^{\prime} \mathrm{E}-7^{\circ} 28^{\prime} \mathrm{E}$, distando $210 \mathrm{~km}$ SSW de Bioko e $220 \mathrm{~km}$ à oeste da África, com uma área estimada em 142 $\mathrm{km}^{2}$ aproximadamente, bastante montanhosa no extremo sul (Jones et al., 1991).

Ao longo de toda LVC ocorrem extensas zonas de fraturas de direção NESW, com registros de manifestações de atividades magmáticas, dadas pela acumulação de massas ígneas e focos vulcânicos intensos. Elas hospedam dezenas de lagos de cratera, dos quais dois, Monoun e Nyos, tiveram protagonismo mundial, devido à liberação catastrófica de gás de $\mathrm{CO}_{2}$, que vitimou mortalmente quase 1800 pessoas e mais de 3000 animais na década de 80 do séc. XX no nordeste dos Camarões (Kling et al., 1987; Freeth et al., 1990; Asaah et al., 2015).

As duas llhas centrais do Golfo da Guiné são associadas a inúmeros ilhéus, sendo os mais representativos os llhéus das Rolas, das Cabras, Bombom, Carroço e Boné do Jóquei formando o Arquipélago de São Tomé e Príncipe, na costa ocidental do continente africano. Análogas a estas, nos extremos norte e sul do setor, assentam-se as ilhas de Bioko (Fernando Pó) e Ano-Bom (Pagalú) respetivamente, compondo a parte oceânica da Linha Vulcânica dos Camarões.

Percorrendo as ilhas, embrenhando em uma vegetação exuberante, entrecortada por numerosos cursos de água, com uma descida progressiva rumo ao litoral, observam-se declives acidentados em altitudes diferenciadas, onde se destacam os principais relevos residuais. 
A ilha de Ano-Bom é o topo erodido de um edifício vulcânico com cerca de $5000 \mathrm{~m}$ de altura, a partir do fundo oceânico, em uma área em que os perfís sísmicos indicam que é construído sobre crosta oceânica (Gorini and Bryan, 1976). Seu ponto de referência mais elevado é o Pico Quioveo (598 m). Ela possui um relevo acidentado, com vales e montanhas íngremes, bem como um lago designado de Lago A Pot ou Mazafin, que é a provável cratera central do antigo vulcão extinto há cerca de 100 mil anos.

$\mathrm{Na}$ ilha de São Tomé, exibe-se o imponente edifício vulcânico com cerca de $5000 \mathrm{~m}$ de altura, desde profundidades oceânicas de $3000 \mathrm{~m}$. A parte mais elevada é o Pico de São Tomé (2024 m), em formato de agulha, na região meridional. Elevações menores também aparecem, como os picos Charutos (1349 m), Oculto (1168 m), Formoso Grande e Pequeno ( 943 m), dentre outros, na região central. A sua rede hidrográfica apresenta uma disposição radial com uma declividade abrupta em direção ao mar, onde os principais rios são Rio D'Ouro, Manuel Jorge, Contador, Lembá, Abade, Prováz e ló Grande, que é o maior de todos, sendo que cerca de $70 \%$ dos rios nacionais são originários da Lagoa Amélia (Munhá et al., 2007).

$\mathrm{Na}$ ilha do Príncipe pode-se vislumbrar o Pico do Príncipe (948 m) e o Pico Papagaio $(680 \mathrm{~m})$ constituindo as principais referências paisagísticas locais. $O$ rio de maior importância é o Papagaio (Jones et al., 1991).

O Golfo da Guiné apresenta clima equatorial, com uma grande variação de temperatura ao longo do ano, sendo que a média anual é de aproximadamente $27^{\circ} \mathrm{C}$, em duas principais estações. A pluviosidade anual é intensa durante todo ano (estação chuvosa), com exceção do período compreendido de junho á setembro, denominado de gravana (estação seca), existindo um período análogo (dezembro á fevereiro) que apresenta baixa pluviosidade. O clima equatorial e a natureza dos solos favorecem o desenvolvimento de coberturas vegetais densas, gerando formações herbáceas constituídas por árvores e arbustos, sendo que o solo originário de rochas ígneas é fértil e de extrema importância para a plantação agrícola desenvolvida nas ilhas. A flora e fauna regional comportam herança de espécies endémicas, que advém da sua longa evolução sem contato com o continente africano, distanciado por mais de uma centena de quilómetros.

Nas três ilhas estudadas, que representam a parte emergente de montanhas oceânicas, o relevo apresenta-se acidentado e as imponentes coberturas vegetais 
dificultam a penetração humana, características presenciadas durante o trabalho de campo.

\subsection{Contexto Tectônico da Linha Vulcânica dos Camarões}

A Linha Vulcânica dos Camarões se assenta sobre a litosfera oceânica do Atlântico pós-jurássico (120 Ma) e a litosfera continental pan-africana de $600 \mathrm{Ma}$ (Nkouathio et al., 2008), figura 1. Elas são interceptadas por um intervalo transicional intermediário, que foi delimitado sismicamente, como Limite de Fronteira OceânicoContinental (Halliday et al., 1988; Lee et al., 1994). Considerada e interpretada como uma grande zona de cisalhamento, gerada durante a abertura do Oceano Atlântico, a LVC apresenta uma ligação com o lineamento de Pernambuco na América do Sul, através da zona de cisalhamento na África central, nas proximidades de Adamawa. A LVC encontra-se subdividida estruturalmente por uma imponente rede de falhas articuladas a um sistema de horst e graben interpolado (Gèze, 1941; Déruelle et al., 1991; Ngako et al., 2006).

Apresentando uma extensão de aproximadamente $1700 \mathrm{Km}$ de comprimento e $100 \mathrm{Km}$ de largura (Déruelle et al., 2007; Njome and de Wit, 2014), de sudoeste ao nordeste, a LVC se alonga da Ilha de Ano-Bom no Golfo da Guiné ao Lago Chade no interior do continente, sendo este um alinhamento tectono-magmático ativo orientado na direção $\mathrm{N} 30^{\circ} \mathrm{E}$. Os contornos da LVC, que outrora apresentava apenas um formato em " $Y$ ", foram redefinidos recentemente em forma de leque, com um ramo que diverge para Biu no nordeste da Nigéria, outra ramificação a NE para Kapsiki, e por fim, outra continuidade para Adamawa a ENE nos Camarões, em conformidade com a figura 2 (Njome and de Wit, 2014).

Os principais centros vulcânicos do setor continental da LVC, Monte Camarões, Manengouba, Bambouto e Oku, são separados pelos grabens vulcânicos Kumba, Mbo e Noun e classificados como monogenéticos, enquanto que as montanhas e planaltos foram descritos como poligenéticos (Sato et al., 1990). Os vulcões poligenéticos têm origem no manto superior astenosférico e os monogenéticos com origem no manto litosférico subcontinental. No entanto, Nkouathio et al. $(2002,2008)$ sugere a origem dos vulcões monogenéticos (Kumba graben) na camada do manto astenosférico. Além disso, numerosos complexos anelares anorogênicos ocorrem ao longo da LVC, com idades entre 70 e $30 \mathrm{Ma}$. 
Grande parte do embasamento da LVC, na região sul da parte continental, situa-se sobre o Cinturão de Oubanguides, formado durante o processo de amalgamação do Supercontinente Gondwana, compreendendo rochas graníticas de idade pan-africana (Lasserre et al., 1978).

Nessa zona, o cinturão é cortado por uma série de falhas ativas constituindo a Zona de Cisalhamento da África Central (CASZ - Central African Shear Zone), que se estende para leste, até a região de Darfur no Sudão (Browne and Fairhead,1983; Moreau et al.,1987; Wilson and Guiraud,1992; Adams et al., 2015). Ao longo da parte norte da LVC ocorre a Calha de Benue (Benue Trough), uma importante estrutura geológica de idade cretácea, com extensão de $1000 \mathrm{Km}$ a nordeste, de Benin ao Lago Chad (Figura 2). Fitton $(1980,1987)$ sugeriu uma origem similar para as duas estruturas maiores, a LVC e a Calha de Benue.

Localizadas no Golfo da Guiné, as ilhas vulcânicas encontram-se instaladas sobre a crosta oceânica do Atlântico Sul, com idade entre 120 e 80 Ma (Emery and Uchupi, 1984; Moreau et al., 1987; Meyers and Rosendahl, 1991; Meyers et al., 1998; Burke, 2001; Yokoyama et al., 2007; Njome and de Wit, 2014). O alinhamento se estende por $700 \mathrm{Km}$, rumo ao oceano, compreendendo três grandes edifícios vulcânicos, um em cada uma das ilhas, Ano-Bom, São Tomé e Príncipe. Três outros grandes vulcões se encontram na llha de Bioko (Santa Isabel, Biao e San Carlos), sobre a plataforma continental e, além disso há dois montes submarinos (seamounts) alinhados, um deles entre São Tomé e Príncipe, e o outro entre Príncipe e Bioko (Figura 2).

Alguns trabalhos dão ênfase de que as atividades magmáticas na LVC abrangem um longo período, onde vários maciços plutónicos e algumas rochas vulcânicas deixaram de ser ativas há mais de 50 Ma (Moundi et al., 1996; Okomo Atouba et al., 2016). No setor continental, vulcões ativos são observados em Mandara desde o final do Eoceno há $36 \mathrm{Ma}$ (Fitton and Dunlop, 1985), e na contraparte oceânica são observados na llha do Príncipe desde o Oligoceno, há 31 Ma (Dunlop and Fitton, 1979). O Monte Camarões é o único vulcão ativo do alinhamento, com registro de atividades recentes no ano 2000. 


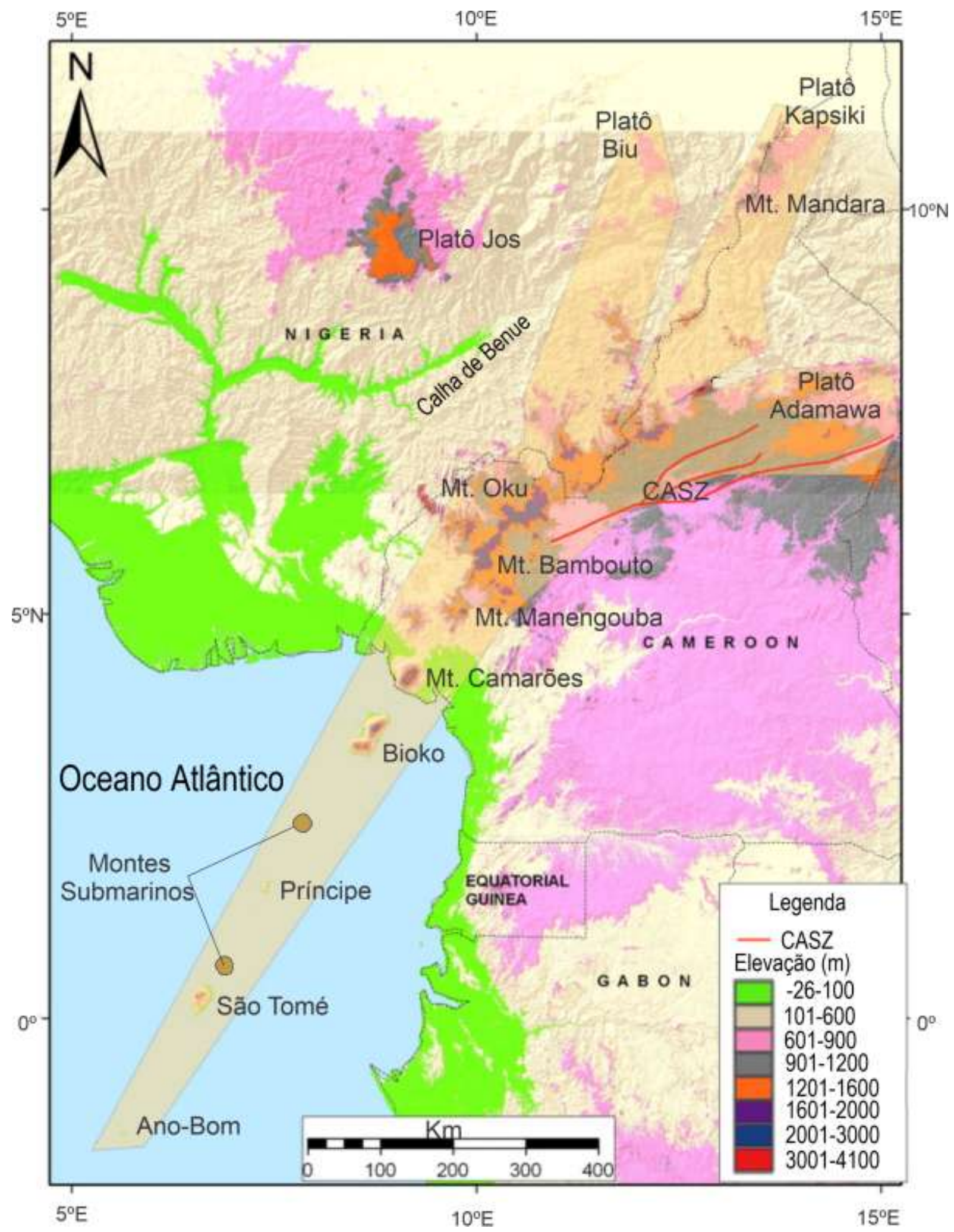

Figura 2: Representação da Linha Vulcânica dos Camarões em formato de leque. Modificado de Njome and de Wit (2014). 


\subsection{Contexto petrográfico da Linha Vulcânica dos Camarões}

Segundo Déruelle et al. (2007), as rochas do alinhamento dos Camarões, no setor continental, são tipicamente alcalinas. A sequência litológica das séries diferenciadas é completa, e inclui lavas máficas basálticas (basaltos alcalinos, picritos e hawaiítos), intermediárias (mugearítos e benmoreítos) e lavas félsicas (fonólitos, traquitos e riolitos alcalinos). A exceção são as lavas do Monte Etinde, fortemente insaturadas e definidas como nefelinitos (Nkoumbou et al., 1995). Comparando os setores continental e oceânico, estes autores relatam evidências de um hiato que demarca as lavas máficas das félsicas, em que traquitos são mais abundantes no setor continental, e que fonolitos, menos ricos em sílica, aparecem no setor oceânico, onde não se observam riolitos, estando presentes os diferentes litotipos máficos nos dois setores do alinhamento vulcânico.

Nos complexos intrusivos da região continental da LVC, as rochas mais representativas são granitos e sienitos. Gabros, dioritos e monzonitos aparecem de forma subordinadas, e ocasionalmente rochas vulcânicas diferenciadas, tais como traquitos e riolitos (Jacquemin et al., 1982; Déruelle et al., 1991; Njonfang et al., 1992).

Os grandes planaltos vulcânicos de Ngaoundéré, Kapsiki, Biu e Mandara, caracterizam a região norte da LVC. O planalto de Ngaoundéré é formado por basanitos e basaltos alcalinos cobertos por fluxos fonolíticos e traquíticos (Marzoli et al., 1999; Nkouandou and Temdjim, 2011; Gountié Dedzo et al., 2019; Tiabou et al., 2019). O planalto de Biu compreende lavas basaníticas a basálticas de transição (Rankenburg et al., 2005), enquanto que, no de Kapsiki, há um predomínio alcalino, composto por lavas félsicas e lavas máficas (Ngounouno and Deruelle, 1997; Tamen et al., 2015). Por sua vez, as montanhas Mandara são constituídas de basaltos alcalinos com inclusões de xenólitos mantélicos, além de basanitos, mugearitos, e litotipos mais evoluídos como riolitos, fonolitos e traquitos (Nono et al., 1994; Marzoli et al., 1999; Déruelle et al., 2000; Rankenburg et al., 2005; Tamen et al., 2015).

Segundo Yokoyama et al. (2007) e Njome and de Wit (2014), na zona de transição oceano-continente, as lavas de Bioko e Monte Camarões são principalmente basálticas.

No caso das três ilhas assentadas no assoalho oceânico do Golfo da Guiné, Ano-Bom, São Tomé e Príncipe, as rochas vulcânicas nelas contidas abrangem um leque vasto, desde depósitos piroclásticos variados, acompanhando picro-basaltos, 
basaltos, basanitos e tefritos a rochas intermediárias traquifonoliticas e fonotefriticas, bem como termos mais evoluídos como traquitos e fonolitos.

\subsection{Contexto geoquímico da Linha Vulcânica dos Camarões}

O magmatismo intraplaca oceânico-continental na extensão da LVC coincide com a tectônica extensional no centro e norte do continente africano durante o Cretáceo e Cenozóico. Quanto às ilhas que compõem o sector oceânico da LVC, diversos pesquisadores enfatizam que a pluma de Santa Helena poderia ser responsável pela sua formação, pois os basaltos do alinhamento vulcânico apresentam composições similares em oligoelementos (Fitton, 1980; Halliday et al., 1988, 1990; Aka et al., 2004). Entretanto, as rochas vulcânicas do hot spot Santa Helena exibem um padrão de ${ }^{206} \mathrm{~Pb} /{ }^{204} \mathrm{~Pb},{ }^{208} \mathrm{~Pb} /{ }^{204} \mathrm{~Pb}$ e ${ }^{207} \mathrm{~Pb} /{ }^{204} \mathrm{~Pb}$ mais radiogênico, o que sugere que provavelmente outras fontes do manto, possivelmente em diferentes profundidades, devam estar envolvidas na origem dos basaltos do setor oceânico da LVC (Njome and de Wit, 2014).

As composições isotópicas de Sr e $\mathrm{Nd}$ atestam que a fonte dos magmas da LVC é sublitosférica e que a crosta continental não desempenha qualquer papel significativo em sua gênese (Njome and de Wit, 2014). Os dados geoquímicos parecem confirmar que os magmas, principalmente alcalinos, se originam da ressurgência profunda do manto, acima da descontinuidade $410 \mathrm{~km}$, com mistura variável de pelo menos quatro membros distintos (DMM, HIMU, FOZO e EM-I), com diferentes graus de fusão parcial. Lavas intermediárias incomuns podem se originar através da mistura entre eles.

Ainda em conformidade com Njome and de Wit (2014), metassomatismo de afinidade carbonatítica afetou o manto litosférico durante a subida, e componentes DMM e FOZO foram envolvidos na gênese dos magmas parentais da LVC. 


\section{METODOLOGIA}

Para atingir os objetivos preconizados na presente dissertação, e colaborar para um melhor conhecimento do setor oceânico da LVC, tendo em vista a existência de informações anteriores realizadas em 2010, essencialmente relativas à Ilha de São Tomé, por ocasião do trabalho de conclusão do curso do autor, será concentrada nesta dissertação a atenção para as ilhas de Príncipe e Ano-Bom. O reconhecimento geológico dessas duas ilhas foi efetuado, bem como a coleta de amostras para obter informações petrográficas, geoquímicas e para efetuar algumas datações radiométricas pelo método Ar-Ar.

Todas as amostras coletadas seriam estudadas petrograficamente, para conhecer a composição mineralógica. Análises geoquímicas de rocha total seriam realizadas por FRX, para determinar os teores de elementos maiores, menores e traços, como traçadores dos processos petrogenéticos. Análises isotópicas de $\mathrm{Sr}$, $\mathrm{Nd}$ e $\mathrm{Pb}$ seriam efetuadas em amostras escolhidas, através de espectrometria de massa termoiônica, no intuito de averiguar melhor a natureza das fontes envolvidas no magmatismo e buscar interpretar possíveis processos que pudessem ter afetado de forma significativa a composição das rochas.

Por fim, tendo em vista que já existe uma série de datações K-Ar para as rochas da llha de São Tomé, seriam realizadas análises geocronológicas pelo método ${ }^{40} \mathrm{Ar} /{ }^{39} \mathrm{Ar}$ em rochas das outras duas ilhas, para verificar as possíveis correlações com São Tomé e com as outras rochas magmáticas da LVC.

\subsection{Reconhecimento geológico e coleta de amostras}

Foram reunidas todas as informações existentes possíveis, através de consultas bibliográficas e cartográficas preliminares, contemplando aspectos regionais e locais fundamentais do setor oceânico da LVC. Com base nessas informações, foi elaborado um plano para o trabalho de campo e respectiva coleta de amostras.

O levantamento bibliográfico direcionado ao trabalho de campo foi realizado em sites e trabalhos impressos pré-existentes para a contextualização geológica, e feita uma abordagem aos elementos fisiográficos mais representativos nos mapas/esboços geológicos, no intuito de traçar estratégias de avaliação destes elementos em campo para obter amostras reprentativas dos litotipos existentes, para o posterior estudo aprofundado nos laboratórios do IGc-USP. O processo de 
amostragem in situ foi realizado em duas etapas distintas, sendo que a primeira ocorreu em meados de junho de 2018, que obteve um total de quinze amostras na ilha de São Tomé (8) e na ilha do Príncipe (7).

Tabela 1: Relação das amostras coletadas em campo para devidos estudos analíticos.

\begin{tabular}{|c|c|c|c|c|c|c|}
\hline \multirow{2}{*}{ Ilha } & \multirow{2}{*}{ Amostra } & \multirow{2}{*}{ Litotipo } & \multirow{2}{*}{ Localização } & \multicolumn{3}{|c|}{ Métodos } \\
\hline & & & & FRX & Isótopos & Ar-Ar \\
\hline \multirow{13}{*}{ São Tomé } & P1-Al & Basalto & Aguá Izé & & & \\
\hline & P2-AD & Olivina basalto & Alto D'ouro & $\mathbf{X}$ & & \\
\hline & P3-PM & Basalto & Pedreira de Mesquita & & & \\
\hline & P4-CG & Basanito & Guadalupe & $\mathbf{X}$ & & \\
\hline & P5-DN & Basalto & Diodo Nunes & & & \\
\hline & P6-PM & Basanito & Pico de Micoló & & & \\
\hline & P7-SN & Tefrito & São Nicolau & & & \\
\hline & P8-PA & Tefrito & Pedreira Algés (RMJ) & & & \\
\hline & P9-DA & Picro-basalto & Dona Augusta & $\mathbf{X}$ & & \\
\hline & P10-PP & Basanito & Praia Piscina & & & \\
\hline & P11-RP & Basanito & Ribeira Peixe & $\mathbf{X}$ & & \\
\hline & P12A-IC & Traquito & Ilhéu das Cabras & $\mathbf{X}$ & $\mathbf{X}$ & $\mathbf{X}$ \\
\hline & P12B-IC & Traquito & Ilhéu das Cabras & & & \\
\hline \multirow{14}{*}{ Príncipe } & L1-ST & Fonotefrito & Roça Sta Trindade & $X$ & $\mathbf{X}$ & $\mathbf{X}$ \\
\hline & L2-RS & Basanito & Roça Sundy & & & \\
\hline & L3-PC & Olivina basalto & Praia Cajú & & & \\
\hline & L4-PB & Olivina basalto & Praia Banana & & & \\
\hline & L5-TV & Basanito & Terreiro Velho & $\mathbf{X}$ & $\mathbf{X}$ & $\mathbf{X}$ \\
\hline & L6A-PP & Fonolito & Pedreira Porto Real & $\mathbf{X}$ & $\mathbf{X}$ & $\mathbf{X}$ \\
\hline & L6B-PP & Fonolito & Pedreira Porto Real & & & \\
\hline & L7-SN & Tefrifonolito & Baracão & & & \\
\hline & L8-PA & Olivina basalto & Praia Évora & & & \\
\hline & L9-DA & Tefrifonolito & São Joaquim & & & \\
\hline & L10-RP & Fonolito & Ribeira Fria & $X$ & $X$ & $X$ \\
\hline & L11-PP & Traquiandesito & Paredão do Pico & $\mathbf{X}$ & $\mathbf{X}$ & $\mathbf{X}$ \\
\hline & L12A-RF & Traquifonolito & Pico Ribeira Fria & & & \\
\hline & L12B-RF & Traquifonolito & Pico Ribeira Fria & & & \\
\hline \multirow{9}{*}{ Ano-Bom } & $A B 1-P C$ & Olivina basalto & Pedreira Central & & & \\
\hline & AB2-LP & Olivina basalto & Lago a Pot & & & \\
\hline & AB3-PF & Traquito & Pico del Fuego & $\mathbf{X}$ & $X$ & $X$ \\
\hline & AB4-AW & Basanito & Awal & $\mathbf{X}$ & $\mathbf{X}$ & $\mathbf{X}$ \\
\hline & AB5-MB & Picro-basalto & Mabana & $X$ & $X$ & $\mathbf{X}$ \\
\hline & AB6-PP & Basalto & Praia Palian & & & \\
\hline & $A B 7-A B$ & Basalto & Água bobô & $X$ & $X$ & $X$ \\
\hline & AB8-MA & Basalto & Morro da Antena & & & \\
\hline & AB9-PC & Picro-basalto & Pedreira Central & $X$ & & $\mathbf{x}$ \\
\hline
\end{tabular}


A segunda etapa, entre janeiro e fevereiro de 2019, foi realizada através de expedições efetuadas pelo autor. Uma coleta adicional de vinte e uma amostras foi efetuada nas ilhas de São Tomé (5), Príncipe (7) e Ano-Bom (9). Os trajetos entre as ilhas foram realizadas por via aérea, e boa parte da amostragem foi efetuada por barco. Nessa etapa, houve apoio financeiro do (CPGeo) e logístico da (UN Habitat STP). A tabela 1 reune a lista das amostras coletadas nas três ilhas, e indica as análises de FRX, geoquímica isotópica e datações Ar-Ar que foram realizadas.

\subsection{Preparação de lâminas delgadas de rocha}

Para a caracterização petrográfica foram confecionadas lâminas delgadas para todas as amostras coletadas (36), no setor de laminação do IGc-USP. As análises petrográficas das seções delgadas foram realizadas no Laboratório de Microscopia Petrográfica do IGc-USP, com utilização do microscópio sob luz transmitida, marca Olympus ${ }^{T M}$ modelo BXP-40, para determinar a mineralogia composicional, percentual mineral e relações texturais entre os minerais constituintes. A nomenclatura dos litotipos foi feita a partir de estimativas visuais, dentre outras informações relevantes para a compreensão da geologia local. A análise petrográfica foi fundamental para a seleção de amostras que foram preparadas para as análises geoquímicas e isotópicas.

As fotomicrografias foram obtidas através da câmera digital modelo Olympus $^{T M}$ E-330 acoplado ao microscópio Olympus ${ }^{T M}$ modelo BX-50, do Laboratório de Microscopia Ótica do IGc-USP.

\subsection{Preparação de amostras para análise de Rocha Total}

Com base na descrição petrográfica, foram selecionadas as amostras que teriam análise em rocha total por Fluorescência de Raio $X$, bem como análise isotópica de $\mathrm{Sr}, \mathrm{Nd}$ e $\mathrm{Pb}$. Essas amostras foram tratadas inicialmente no Laboratório de Separação e Preparação de amostras (LSP) do CPGeo e posteriormente no Laboratório de Tratamento de Amostras (LTA) do Núcleo de Apoio a Pesquisa Geoanalítica (NAP-Geoanalítica) do IGc-USP. A preparação de amostras foi realizada pelo autor, sob supervisão do técnico responsável, Vasco António Loios, seguindo os seguintes procedimentos:

> Limpeza manual das superfícies intemperizadas da rocha com auxílio de martelo, bem como remoção das partes serradas na laminação; 
> Britagem e seleção dos fragmentos de rocha e redução destes em pilão de aço inoxidável para dimensões de aproximadamente $0,5 \mathrm{~cm}$;

> Quarteamento do material cominuído em pilão de aço e separação em alíquotas suficientes para moagem e arquivamento;

> Pulverização em moinho de anéis durante um minuto para obtenção de pó com partículas de tamanho inferior a 200 mesh;

\subsection{Estudo de geoquímica elemental (Rocha Total)}

Quinze amostras foram selecionadas para análise química de rocha total por Fluorescência de Raios X (FRX) de elementos maiores, menores e traços (Tabela 1), utilizando equipamento Philips, modelo PW2400. Elas foram conduzidas ao Laboratório de Tratamento de Amostras dentro dos parâmetros exigidos para o estudo geoquímico elemental, onde foi efetuada a micronização para confecção de pastilhas de pó prensado, por meio de prensa hidráulica especial, a fusão para formar disco de vidro. Detalhes dos procedimentos metodológicos das amostras e da análise seguiram os padrões estabelecidos por Mori et al. (1999).

Todos os procedimentos laboratoriais de pastilhas fundidas e pastilhas de pó prensado foram feitos sob a supervisão do técnico responsável José Paulo Sertek. Os resultados obtidos constituíram um banco de dados que foi tratado no software Excel. O cálculo das normas CIPW e os respectivos diagramas foram feitos no software GCDkit (Geochemical Data Toolkit in R, versão 3.0 para Windows), de Janousěk et al. (2006).

\subsection{Geoquímica isotópica de $\mathrm{Sr}, \mathrm{Nd}$ e $\mathrm{Pb}$}

Cinco amostras da llha do Príncipe, quatro de Ano Bom e uma de São Tomé foram selecionadas e encaminhadas para análises de geoquímica isotópica em rocha total, de $\mathrm{Sr}, \mathrm{Nd}$ e $\mathrm{Pb}$ (Tabela 1). Foram seguidos todos os procedimentos primários que antecedem a análise, como a esterilização dos Savilex com detergente, água destilada e Milli-Q e posteriormente deixando acidificar em $\mathrm{HNO}_{3}$. Todas as normas técnicas laboratoriais do Centro de Pesquisa Geocronológica do Instituto de Geociências da USP foram seguidas, conforme Magdaleno et al. (2017). As análises de $\mathrm{Sr}$ e $\mathrm{Nd}$ foram efetuadas em um espectrômetro de massas de termoionização (TIMS) - Thermo Triton, e as razões isotópicas de ${ }^{87} \mathrm{Sr} /{ }^{86} \mathrm{Sr}$ foram 
normalizadas para o valor ${ }^{86} \mathrm{Sr} /{ }^{88} \mathrm{Sr}=0,1194 \mathrm{e}{ }^{146} \mathrm{Nd} /{ }^{144} \mathrm{Nd}=0,7219$ (DePaolo, 1981), respectivamente, onde ${ }^{143} \mathrm{Nd} /{ }^{144} \mathrm{NdCHUR}=0,512638$ (Hamilton et al., 1983).

As análises foram realizadas pela estudante Alana Dantas, sob supervisão da analista responsável de laboratório, Liliana Petronilho, a partir de amostras de rocha total pulverizadas e analisadas para $\mathrm{Sr}, \mathrm{Nd}$ e $\mathrm{Pb}$. Elas foram efetuadas em um espectrómetro de massas por termoionização (TIMS) - Finnigan MAT 262, e as razões isotópicas foram corrigidas para fracionamento de massa de $0.12 \% / \mathrm{u}$.m.a (razão ${ }^{207} \mathrm{~Pb} /{ }^{204} \mathrm{~Pb}$ ) e $0.13 \% /$ u.m.a (razões ${ }^{206} \mathrm{~Pb} /{ }^{204} \mathrm{~Pb}$ e ${ }^{208} \mathrm{~Pb} /{ }^{204} \mathrm{~Pb}$ ).

Os diagramas foram feitos no software Excel e Corel Draw 2020.

\subsection{Estudos geocronológicos pelo método ${ }^{40} \mathrm{Ar}-{ }^{39} \mathrm{Ar}$}

As mesmas dez amostras que foram submetidas a análises isotópicas foram selecionadas para determinação de idades $\mathrm{Ar}$-Ar, acrescentando mais uma amostra de Ano-Bom (Tabela 1). A preparação foi feita em rocha total, e constou de fragmentação em pilão de aço inoxidante, para obter fragmentos da ordem de 3 - 4 $\mathrm{mm}$ em tamanho. Após lavagem em ultrassom e secagem em capela, foram preparadas alíquotas de cerca $100 \mathrm{mg}$ para as análises geocronológicas.

Os fragmentos de rocha foram irradiados por fluxo de neutrons epitermais rápidos no reator de pesquisa TRIGA (CLICIT) da Universidade de Oregon (USA) durante 7 horas contínuas, juntamente com o padrão internacional sanidina Fish Canyon Tuff $(28.01 \pm 0.04 \mathrm{Ma})$. Após o resfriamento da irradiação, as alíquotas foram incluídas em porta-amostra para serem analisadas por aquecimento incremental (step heating), no espectrômetro de massas multicoletor ARGUS VI do CPGeo-IGc-USP. O sistema de extração de argônio utiliza um laser de estado sólido acoplado a uma linha de ultra alto vácuo que funciona online com o espectrômetro. Os isótopos 40 e 36 do argônio foram medidos simultaneamente em 5 coletores Faraday e as idades aparentes foram calculadas para cada etapa de aquecimento, após correções para discriminação de massa, interferências nucleogênicas e contaminação atmosférica. Foram calculadas as idades de fusão total e foram construídos os gráficos de aquecimento com as idades plateau e com as isócronas normais para cada amostra. Para as idades de fusão total, plateau e para confecção das isócronas foram seguidos os procedimentos analíticos descritos em Renne et al. (2009) e Vasconcelos et al. (2002). 


\section{GEOLOGIA DAS ILHAS DO GOLFO DA GUINÉ}

As ilhas que compõem a Linha Vulcânica dos Camarões na costa ocidental do continente africano têm sido objeto de estudos geológicos importantes desde Teixeira, (1949). As três ilhas oceânicas a SW apresentam rochas com composição análoga ao setor continental, formadas, sobretudo, por lavas basálticas. Termos mais evoluídos, como traquitos e fonólitos também estão presentes (Cornen and Maury, 1980; Liotard et al., 1982; Halliday et al., 1990; Lee et al., 1994; Caldeira et al., 2003). Do Terciário à atualidade, a intensa atividade magmática que caracteriza a LVC, insere-se em um mecanismo de rifteamento ativo, sugerindo reminiscência dos processos de fragmentação continental que ocorreram a partir do Cretáceo inferior no Atlântico Sul (Fitton, 1983; Halliday et al., 1988).

\subsection{Ilha de Ano-Bom}

A ilha de Ano-Bom (antiga Pagalu), a menor itha do setor, localizada no Golfo da Guiné, extremo sul da LVC, é a menos conhecida e pertence à Guiné Equatorial. A ilha é considerada topo de um vulcão erodido, com perfil sísmico (Gorini and Bryan, 1976), indicando soerguimento sobre a crosta oceânica, revestida por sedimentos finos. Os primeiros registos geológicos foram da autoria de Schultze (1913), Tyrrell (1934) e Fuster Casas (1954), constando breves descritivas. Basalto alcalino parece ser a rocha predominante na ilha, ocorrendo também termos mais evoluídos, como quartzo traquitos. Não é feita menção à existência de fonolitos.

Trabalhos posteriores (Cornen and Maury, 1980; Liotard et al., 1982), trazem alguma contribuição adicional sobre os litotipos presentes, descrevendo basanitos, hawaiítos, benmoreitos e traquitos super-saturados.

As rochas consideradas mais antigas foram descritas como sendo brechas palagoníticas intrudidas por inúmeros diques basálticos. Traquito é descrito para o Pico del Fuego, nas proximidades da cratera que formou o Lago a Pot ou Mazafin (Figura 3). Segundo Liotard et al. (1982), as rochas mais evoluídas da ilha teriam sido provavelmente geradas por cristalização fracionada de magmas basaníticos, envolvendo minerais como anfibólio, clinopiroxênio e plagioclásio.

Cornen and Maury (1980), para a construção do mapa geológico, subdividem o vulcanismo ocorrido na ilha em três etapas distintas, através de variações etárias. O mais antigo refere-se ao vulcanismo submarino que teria gerado brechas palagoníticas que afloram a leste e oeste da ilha. Estas brechas incluem 
fenocristais de olivina e clinopiroxênio, sendo cortadas por diques subverticais de basanitos, ricos em megacristais de piroxênio e olivina. Elas não foram objeto de datação neste trabalho.

Tabela 2: Datações radiométricas de rochas da ilha de Ano-Bom (LVC).

\begin{tabular}{|l|l|l|l|l|}
\hline Ilha & Litotipo & Método & Idade (Ma) & Referência \\
\hline \multirow{5}{*}{ Ano-Bom } & Basanito & $\mathrm{K}-\mathrm{Ar}$ & $5,35 \pm 0,25$ & Cornen and Maury (1980) \\
\cline { 2 - 6 } & Basalto & $\mathrm{Rb}-\mathrm{Sr}$ & 5,0 & Fitton and Hughes (1977) \\
\cline { 2 - 6 } & Basalto & $\mathrm{K}-\mathrm{Ar}$ & $4,9 \pm 0,2$ & Lee et al. (1994) \\
\cline { 2 - 6 } & Basalto & $\mathrm{K}-\mathrm{Ar}$ & $4,8 \pm 0,2$ & Lee et al. (1994) \\
\cline { 2 - 6 } & Basanito & $\mathrm{K}-\mathrm{Ar}$ & $4,8 \pm 0,2$ & Lee et al. (1994) \\
\cline { 2 - 6 } & Tristanito & $\mathrm{K}-\mathrm{Ar}$ & $3,9 \pm 0,2$ & Cornen and Maury (1980) \\
\cline { 2 - 6 } & Basanito & $\mathrm{K}-\mathrm{Ar}$ & $0,4 \pm 0,1$ & Lee et al. (1994) \\
\cline { 2 - 5 } & Basanito & $\mathrm{K}-\mathrm{Ar}$ & $0,20 \pm 0,01$ & Aka et al. (2004) \\
\cline { 2 - 5 } & Traquibasalto & $\mathrm{K}-\mathrm{Ar}$ & $0,08 \pm 0,01$ & Aka et al. (2004) \\
\cline { 2 - 5 } & Basanito & $\mathrm{Ar}-\mathrm{Ar}$ & $<1$ & Lee et al. (1994) \\
\cline { 2 - 5 } & Basanito & $\mathrm{Ar}-\mathrm{Ar}$ & $<1$ & Lee et al. (1994) \\
\hline
\end{tabular}

Em um segundo momento, um vulcanismo basáltico, formado por fluxos basaníticos em camadas (18,4 Ma), recobriu a maior parte da ilha, e foi cortado por vários diques $(5,35 \pm 0,25 \mathrm{Ma})$ relacionados à terceira erupção.

Por fim, o último evento vulcânico colocou material tristanítico $(3,9 \pm 0,2 \mathrm{Ma})$ e traquítico supersaturado, sendo este último correspondente ao Pico del Fuego, que corta um cone mais largo, com cratera bem preservada (Lago a Pot). Este evento vulcânico do Pico del Fuego, foi responsável pela erupção a norte e sul de fluxos de lavas basaníticas jovens (2,6 Ma), ricas em nódulos peridotíticos, e pelo fluxo piroclástico com características basaniticas que formou o ilhéu de Tortuga a NNE de Ano-Bom, conforme a figura 3.

Piper and Richardson (1972), em seu estudo paleomagnético, reportam duas séries de fluxo de lavas com idades de 18,4 Ma e 2,6 Ma, datadas pelo método K-Ar, em rochas basálticas da ilha. No entanto, estas idades são controversas. Cornen and Maury (1980) dataram um dos diques basaníticos que cortam o presumível fluxo de lava mais antigo e obteve idade de 5,35 $\pm 0,25$. Estudos posteriormente realizados por Lee et al. (1994) obtiveram idades bem mais jovens para as lavas mais antigas e mais recentes, pelo método ${ }^{40} \mathrm{Ar} /{ }^{39} \mathrm{Ar}$ de $4,8 \pm 0,2 \mathrm{Ma}$ e $<1 \mathrm{Ma}$ (Tabela 2) respectivamente, nas mesmas amostras por Piper and Richardson (1972). Aka et al. (2004) trouxeram idades mais recentes para a ilha. 
$\mathrm{Na}$ figura 3 está representada no mapa geológico a localização das amostras coletadas para os diversos estudos geológicos na ilha.

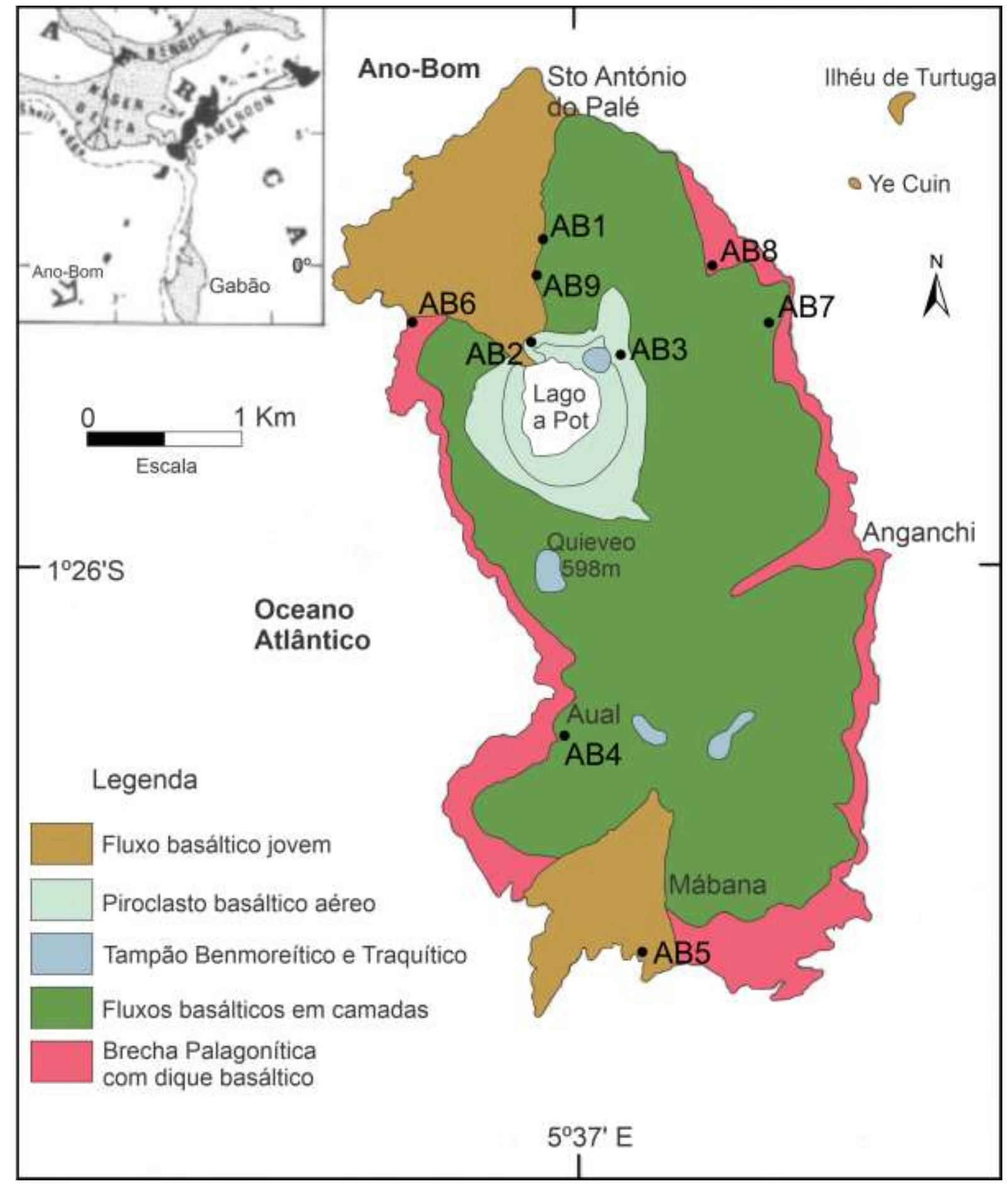

Figura 3:Mapa geológico e localização de amostras coletas. Adaptado de Cornen and Maury (1980).

\subsection{Ilha de São Tomé}

Os conhecimentos geológicos da ilha de São Tomé tiveram seu início a partir dos trabalhos de Teixeira (1949) e Neiva (1956a), através de esboços geológicos na tentativa de definir os principais litotipos que caracterizam a ilha. 
À semelhança das outras ilhas do Golfo da Guiné, a ilha de São Tomé é fundamentalmente de origem basáltica. Na região nordeste da ilha aparecem cones vulcânicos, escoadas lávicas e materiais piroclásticos subaéreos. As atividades vulcânicas refletem diversos ciclos eruptivos, sendo o mais recente responsável por grande parte das rochas aflorantes. Sedimentos jovens capeiam as rochas basálticas nas zonas mais baixas da ilha (Caldeira and Munhá, 2002).

Atendendo que em áreas vulcânicas não é possível fazer uso de métodos convencionais de correlação estratigráfica para reconstruir a história geológica, foi no âmbito da elaboração do mapa geológico da ilha de São Tomé, em escala 1: 25 000, por Munhá et al. (2007), que foram definidas quatro principais unidades vucano-estratigráficas (Figura 4 e $4 \mathrm{a}$ ). Na ocasião, com base em diversos dados geocronológicos realizados nos laboratórios do CPGeo-USP (Tabela 3), foram definidos a Formação Ilhéu das Cabras (13 Ma), o Complexo Vulcânico Mizambú (6 à $8 \mathrm{Ma})$, o Complexo Ribeira Afonso (2,5 à $5 \mathrm{Ma})$ e o Complexo São Tomé (<1,5 Ma) por Caldeira et al. (2003), considerados como originários de pulsos magmáticos distintos provenientes de uma mesma fonte mantélica (Lopes, 2010).

Grunau et al. (1975) datou uma única rocha em 15,7 \pm 0,8 Ma, que era então, a mais antiga na ilha, porém o autor não fez menção de sua real localização. Posteriormente, Fitton and Dunlop (1985) dataram traquitos em 13,25 $\pm 0,45 \mathrm{Ma}$, no Ilhéu das Cabras, que é constituído por dois picos alinhados na direção NE-SW. Esta idade passou a prevalecer, como sendo a idade mais antiga da ilha, pelos pesquisadores. Localizado à NE da llha, o ilhéu inclui condutos vulcânicos dos primórdios da edificação da ilha de São Tomé, que resistiram à erosão devido à estrutura maciça da rocha (Munhá et al., 2007). O maciço é caracterizado por materiais traquíticos, evidenciando um conjunto de fraturas sem direção preferencial, preenchidas por materiais silicosos.

O Complexo Vulcânico de Mizambú é a segunda unidade vulcanoestratigráfica da ilha, com ocorrência nas regiões centro e sul. A unidade é constituída por chaminés e derrames subaéreos fonolíticos e traquifonolíticos, derrames subaéreos basálticos com intercalação de depósitos de lahar e derrames de lava e piroclastos basálticos submarinos caracterizados por lavas almofadas (Munhá et al., 2007). O nome do complexo advém do edifício Mizambú (505 m), constituído por chaminé traquifonolítica com 7,6 Ma (Fitton and Dunlop, 1985). O Morro Micondó (355 m) é constituído por traquifonolito, onde os derrames basálticos 
datados de 7,5 $\pm 2,1$ Ma (Caldeira et al., 2003), são parcialmente cobertos por depósitos de vertente. No Morro Azeitona I, derrames de composição basáltica alcalina a basanítica, na base, são datados de 7,9 \pm 1,1 Ma (Fitton and Dunlop, 1985). Além disso foi obtida a idade de 6,37 $\pm 0,15 \mathrm{Ma}$ na datação de um dos diques da região do Morro Macaco-Capitango por Fitton and Dunlop (1985).

A unidade seguinte, o Complexo Vulcânico Ribeira Afonso, inclui litologias distintas, com destaques para alguns morros e chaminés de derrames basálticos, tais como limburgitos, basaltos alcalinos, basanitos e tefritos, e derrames de lavas félsicas de composição traquítica e fonolítica, com presença de disjunção colunar. A parte inferior destas chaminés está coberta por depósitos de vertente e/ou enxurrada.

Uma série de datações foi realizada por Caldeira et al. (2003), pelo método K-Ar (Tabela 3), em algumas chaminés fonolíticas descarnadas com idades de 4,6 \pm

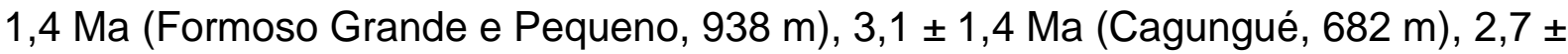
1,5 Ma (Angobó, 207 m), 4,4 \pm 1,4 Ma (Morro Azeitona II, 247 m), 4,1 \pm 2,8 Ma (Pico

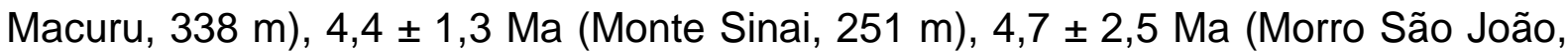
339 m). Além disso, Halliday et al. (1988) obteve 3 Ma para a chaminé de Cão Grande (663 m).

Na região nordeste da ilha, nas localidades de Palmar, Mesquita e Boa Morte, afloram excepcionalmente rochas basálticas levemente alteradas, formando paredões com disjunções colunares, datadas de 2,66 0 0,09 Ma (Fitton and Dunlop, 1985). Finalmente, na região SW da llha ocorre material piroclástico do tipo block and ash flow, evidenciando atividade vulcânica explosiva ligada ao centro vulcânico do Pico Cão Grande.

O complexo São Tomé representa a unidade vulcânica mais nova, com idade inferior a 1,5 Ma (Caldeira et al., 2003; Aka et al., 2004; Tabela 3). Ele cobre a maior proporção do espaço no mapa geológico, abrangendo principalmente a região norte, bem como o extremo sul da ilha. Na região NNE, o Morro Peixe corresponde a um cone piroclástico, constituído por acumulações de bombas, lapilli e cinzas, associados a lavas escoriáceas. 


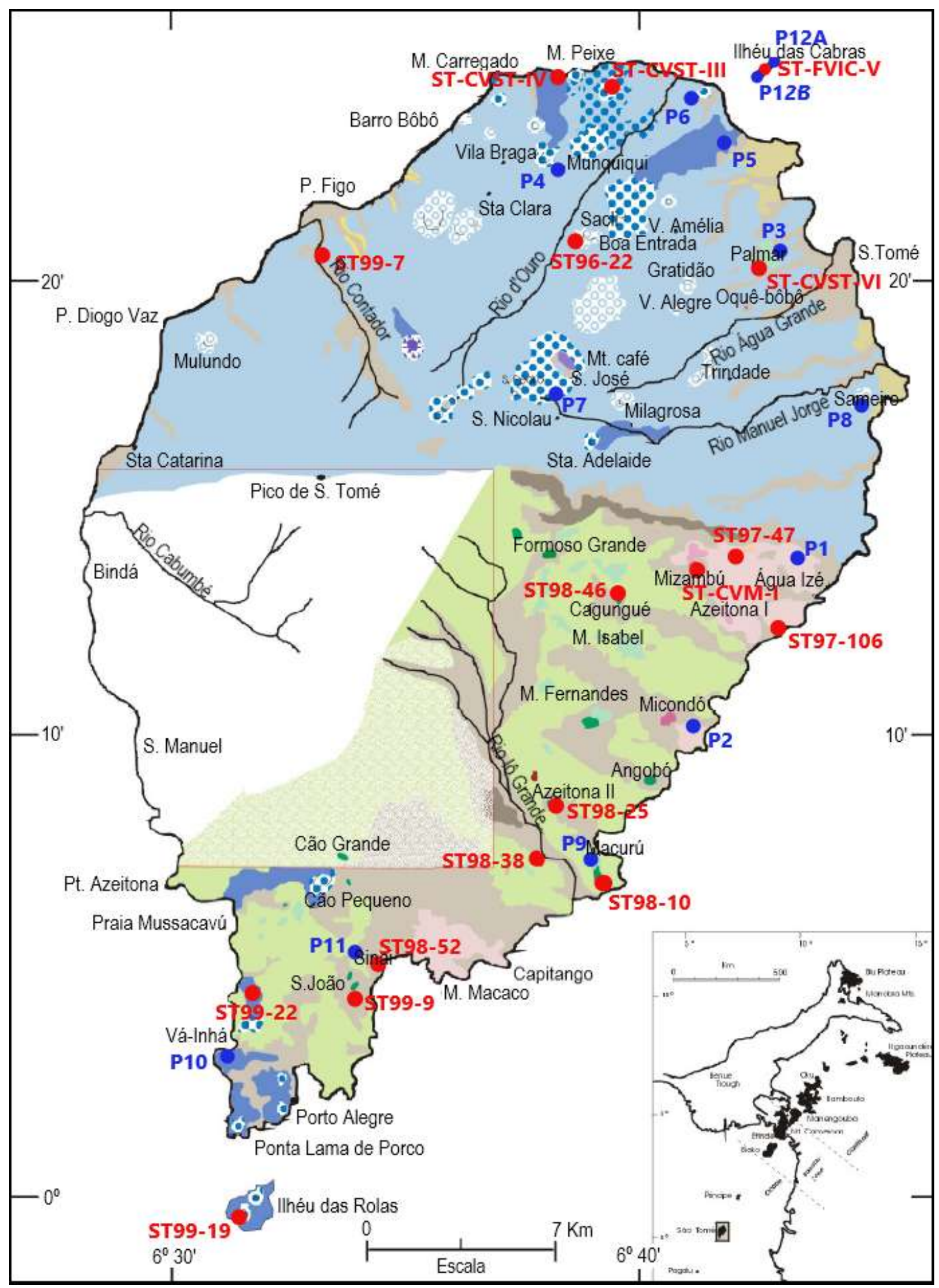

Figura 4: Mapa geológico e localização de pontos de coleta em São Tomé (Caldeira, 2006). Os pontos azuis representam amostras coletadas para essa dissertação e os vermelhos, amostras da monografia (Lopes, 2010). 


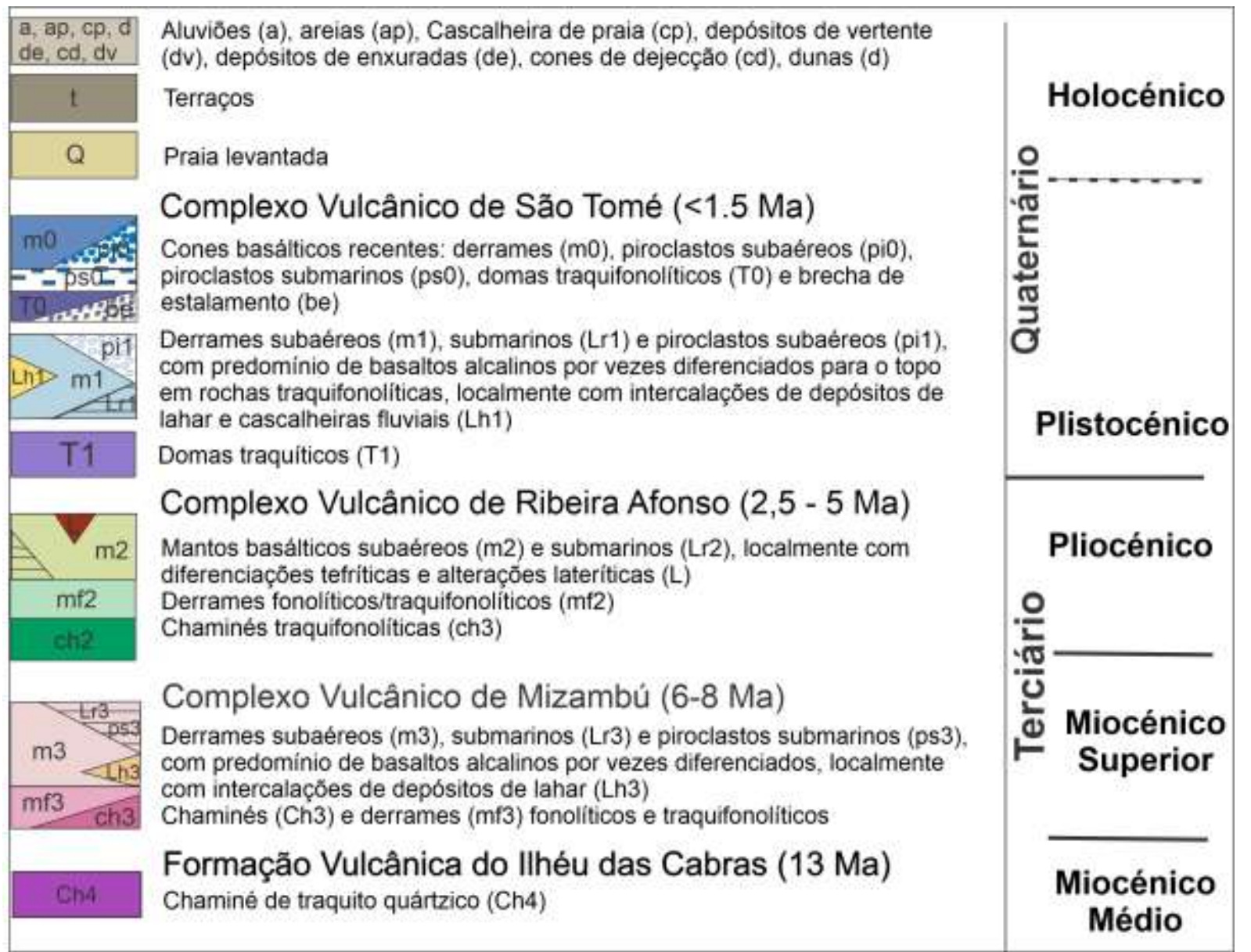

Figura 4a: Legenda do mapa geológico da llha de São Tomé (melhorado de Caldeira, 2006).

O Morro Munquiqui é originário de material piroclástico, constituindo aglomerado vulcânico com blocos e bombas de granulação heterogênea aglutinados por uma matriz de lapilli. O ilhéu das Rolas foi formado por dois edifícios vulcânicos recentes, bem conservados, que emitiram piroclastos do tipo lapilli e lavas basálticas (Munhá et al., 2007).

No litoral $\mathrm{N}$ e NW existem afloramentos de sequências submarinas, por vezes espessas, constituídos por lavas almofadadas e piroclastos submarinos, sobrepostos e/ou ladeados por produtos lávicos subaéreos (Caldeira et al., 2003).

A fase mais antiga do Complexo Vulcânico de São Tomé é representada por dois domos traquíticos, São José com 1,35 \pm 0,08 Ma (Fitton and Dunlop, 1985) e Oquê-Bobô, apresentando forte alteração (Caldeira, 2006). As datações existentes, feitas pelo método K-Ar em rochas das regiões de Ponta Figo e Contador, permitem considerar duas sequências de derrames basálticos, a inferior com idades $0,7 \pm 0,1$ Ma e 0,6 0 0,04 Ma, e a superior com 0,4 0 0,1 Ma (Caldeira and Munhá, 2002). 
Tabela 3: Datações radiométricas de rochas das ilhas de São Tomé e Príncipe (LVC).

\begin{tabular}{|c|c|c|c|c|}
\hline Ilha & Litotipo & Método & Idade (Ma) & Referência \\
\hline \multirow{31}{*}{ São Tomé } & Traquito & $\mathrm{K}-\mathrm{Ar}$ & $15,7 \pm 0,8$ & Grunau et al. (1975) \\
\hline & Traquito & $\mathrm{K}-\mathrm{Ar}$ & $13,25 \pm 0,45$ & Fitton and Dunlop (1985) \\
\hline & Basanito & $\mathrm{K}-\mathrm{Ar}$ & $7,9 \pm 1,1$ & Fitton and Dunlop (1985) \\
\hline & Traquifonolito & $\mathrm{K}-\mathrm{Ar}$ & $7,64 \pm 0,16$ & Fitton and Dunlop (1985) \\
\hline & Basalto & $\mathrm{K}-\mathrm{Ar}$ & $7,6 \pm 2,1$ & Caldeira et al. (2003) \\
\hline & Fonolito & $\mathrm{K}-\mathrm{Ar}$ & $7,5 \pm 2,2$ & Caldeira et al. (2003) \\
\hline & Basanito & $\mathrm{K}-\mathrm{Ar}$ & $6,7 \pm 1,3$ & Caldeira et al. (2003) \\
\hline & Hawaiíto & $\mathrm{K}-\mathrm{Ar}$ & $6,37 \pm 0,15$ & Fitton and Dunlop (1985) \\
\hline & Picro-basalto & $\mathrm{K}-\mathrm{Ar}$ & $5,20 \pm 0,28$ & Aka et al. (2004) \\
\hline & Fonolito & $\mathrm{K}-\mathrm{Ar}$ & $4,7 \pm 2,5$ & Caldeira et al. (2003) \\
\hline & Fonolito & $\mathrm{K}-\mathrm{Ar}$ & $4,6 \pm 1,4$ & Caldeira et al. (2003) \\
\hline & Fonolito & $\mathrm{K}-\mathrm{Ar}$ & $4,4 \pm 1,4$ & Caldeira et al. (2003) \\
\hline & Traquifonolito & $\mathrm{K}-\mathrm{Ar}$ & $4,4 \pm 1,3$ & Caldeira et al. (2003) \\
\hline & Fonolito & $\mathrm{K}-\mathrm{Ar}$ & $4,1 \pm 2,8$ & Caldeira et al. (2003) \\
\hline & Fonolito & $\mathrm{K}-\mathrm{Ar}$ & $3,9 \pm 1,4$ & Caldeira et al. (2003) \\
\hline & Tefrito & $\mathrm{K}-\mathrm{Ar}$ & $3,9 \pm 0,2$ & Caldeira et al. (2003) \\
\hline & Fonolito & $\mathrm{K}-\mathrm{Ar}$ & $3,3 \pm 0,09$ & Fitton and Dunlop (1985) \\
\hline & Fonolito & $\mathrm{K}-\mathrm{Ar}$ & $3,1 \pm 1,4$ & Caldeira et al. (2003) \\
\hline & Fonolito & $\mathrm{K}-\mathrm{Ar}$ & 3 & Halliday et al. (1988) \\
\hline & Traquifonolito & $\mathrm{K}-\mathrm{Ar}$ & $2,9 \pm 1,9$ & Caldeira et al. (2003) \\
\hline & Fonolito & $\mathrm{K}-\mathrm{Ar}$ & $2,7 \pm 1,5$ & Caldeira et al. (2003) \\
\hline & Basanito & $\mathrm{K}-\mathrm{Ar}$ & $2,66 \pm 0,09$ & Fitton and Dunlop (1985) \\
\hline & Basanito & $\mathrm{Rb}-\mathrm{Sr}$ & 2,5 & Hedberg (1968) \\
\hline & Basanito & $\mathrm{K}-\mathrm{Ar}$ & $1,38 \pm 0,08$ & Aka et al. (2004) \\
\hline & Traquito & $\mathrm{K}-\mathrm{Ar}$ & $1,35 \pm 0,08$ & Fitton and Dunlop (1985) \\
\hline & Basalto & $\mathrm{K}-\mathrm{Ar}$ & $0,7 \pm 0,1$ & Caldeira and Munhá (2002) \\
\hline & Basalto & $\mathrm{K}-\mathrm{Ar}$ & $0,6 \pm 0,04$ & Caldeira and Munhá (2002) \\
\hline & Basalto & $\mathrm{K}-\mathrm{Ar}$ & $0,51 \pm 0,06$ & Caldeira and Munhá (2002) \\
\hline & Basalto & $\mathrm{K}-\mathrm{Ar}$ & $0,4 \pm 0,1$ & Caldeira and Munhá (2002) \\
\hline & Basanito & $\mathrm{K}-\mathrm{Ar}$ & $0,3 \pm 0,1$ & Caldeira et al. (2003) \\
\hline & Basanito & $\mathrm{K}-\mathrm{Ar}$ & $0,17 \pm 0,01$ & Aka et al. (2004) \\
\hline \multirow{12}{*}{ Príncipe } & Brecha Palagonítica & $\mathrm{K}-\mathrm{Ar}$ & $30,6 \pm 2,1$ & Dunlop and Fitton (1979) \\
\hline & Basalto & $\mathrm{K}-\mathrm{Ar}$ & $23,6 \pm 0,7$ & Dunlop and Fitton (1979) \\
\hline & Hawaiíto & $\mathrm{K}-\mathrm{Ar}$ & $19,1 \pm 0,5$ & Dunlop and Fitton (1979) \\
\hline & Traquifonolito & $\mathrm{K}-\mathrm{Ar}$ & $6,93 \pm 0,68$ & Dunlop and Fitton (1979) \\
\hline & Fonolito & $\mathrm{Rb}-\mathrm{Sr}$ & $5,9 \pm 0,3$ & Dunlop and Fitton (1979) \\
\hline & Dique & $\mathrm{Rb}-\mathrm{Sr}$ & 5,9 & Lee et al. (1994) \\
\hline & Basanito & $\mathrm{K}-\mathrm{Ar}$ & $5,85 \pm 0,32$ & Aka et al. (2004) \\
\hline & Nefelinito & $\mathrm{K}-\mathrm{Ar}$ & $5,60 \pm 0,32$ & Dunlop and Fitton (1979) \\
\hline & Fonolito & $\mathrm{K}-\mathrm{Ar}$ & $5,48 \pm 0,19$ & Dunlop and Fitton (1979) \\
\hline & Fonolito & $\mathrm{K}-\mathrm{Ar}$ & $5,32 \pm 0,17$ & Dunlop and Fitton (1979) \\
\hline & Tristanito & $\mathrm{K}-\mathrm{Ar}$ & $4,89 \pm 0,15$ & Dunlop and Fitton (1979) \\
\hline & Basanito & $\mathrm{K}-\mathrm{Ar}$ & $3,51 \pm 0,15$ & Dunlop and Fitton (1979) \\
\hline
\end{tabular}


A fase mais recente do complexo Vulcânico de São Tomé corresponde a um conjunto de cones vulcânicos (Tabela 3), com idades K-Ar mais jovens do que 0,4 Ma (Caldeira and Munhá, 2002; Caldeira et al., 2003; Aka et al., 2004).

Nascentes de água carbonática gaseificada, associadas a este vulcanismo, são encontradas nas localidades de Madre Deus, Queluz, Boa Entrada, Pedra Maria, Potó, Caixão Grande e Palha (Munhá et al., 2007).

\subsection{Ilha do Príncipe}

A ilha do Príncipe ainda não possui mapa geológico, mas apresenta esboço geológico representativo da sua constituição litológica (Neiva, 1956b). Neste esboço (Figura 5), a ilha é constituída essencialmente por derrames de lava de natureza basáltica. Ocorrem também rochas fonolíticas mais antigas, bem como traquíticas, tefríticas e andesitos constituindo domos e chaminés. Rochas sedimentares também aparecem na ilha, como é o caso de calcário miocênico e diversos sedimentos recentes de praia levantada. É perceptível em boa parte da ilha uma camada superficial composta por solos lateríticos decorrente da alteração das rochas basálticas, como mostra a figura 5 , acompanhada da localização das amostras coletadas para esta dissertação.

Posteriormente, com base em um conjunto de datações K-Ar, foi definida uma sequência geocronológica para a ilha do Príncipe (Dunlop and Fitton, 1979). Os autores dividiram a geologia da ilha em brecha palagonítica basal $(30,6 \pm 2,1 \mathrm{Ma})$, basalto alcalino (23,6 \pm 0,7 Ma) e hawaiíto $(19,1 \pm 0,5 \mathrm{Ma})$ como as séries de lavas antigas. As séries de lavas mais jovens correspondem a nefelinito $(5,6 \pm 0,32 \mathrm{Ma}) \mathrm{e}$ basanito $(3,51 \pm 0,15 \mathrm{Ma})$, bem como a série de lavas intermediárias, caracterizada por fonolitos $(5,48 \pm 0,19 \mathrm{Ma}$ e 5,32 $\pm 017 \mathrm{Ma})$, tristanito $(4,89 \pm 0,15 \mathrm{Ma})$ e traquifonolito $(6,93 \pm 0,68 \mathrm{Ma})$, conforme a tabela 3 .

Eles relatam que os fonolitos traçam uma isocrona $\mathrm{Rb}-\mathrm{Sr}(5,9 \pm 0,3 \mathrm{Ma})$, em que constam também a tristanito e traquifonolito da série de lavas mais jovens, sugerindo uma relação cogenética, tendo o basanito como magma parental que gerou os fonolitos. Porém descartam essa mesma semelhança entre o basanito e as séries mais antigas. A datação radiométrica mais recente na ilha foi feita por Aka et al. (2004) em um basanito, com 5,85 $\pm 0,32 \mathrm{Ma}$. 
A tabela 3 apresenta 12 datações obtidas até o presente na llha do Príncipe. Dez delas foram obtidas pelo método K-Ar e as duas restantes pelo método $\mathrm{Rb}-\mathrm{Sr}$ (Dunlop and Fitton, 1979; Lee et al., 1994; Aka et al., 2004).

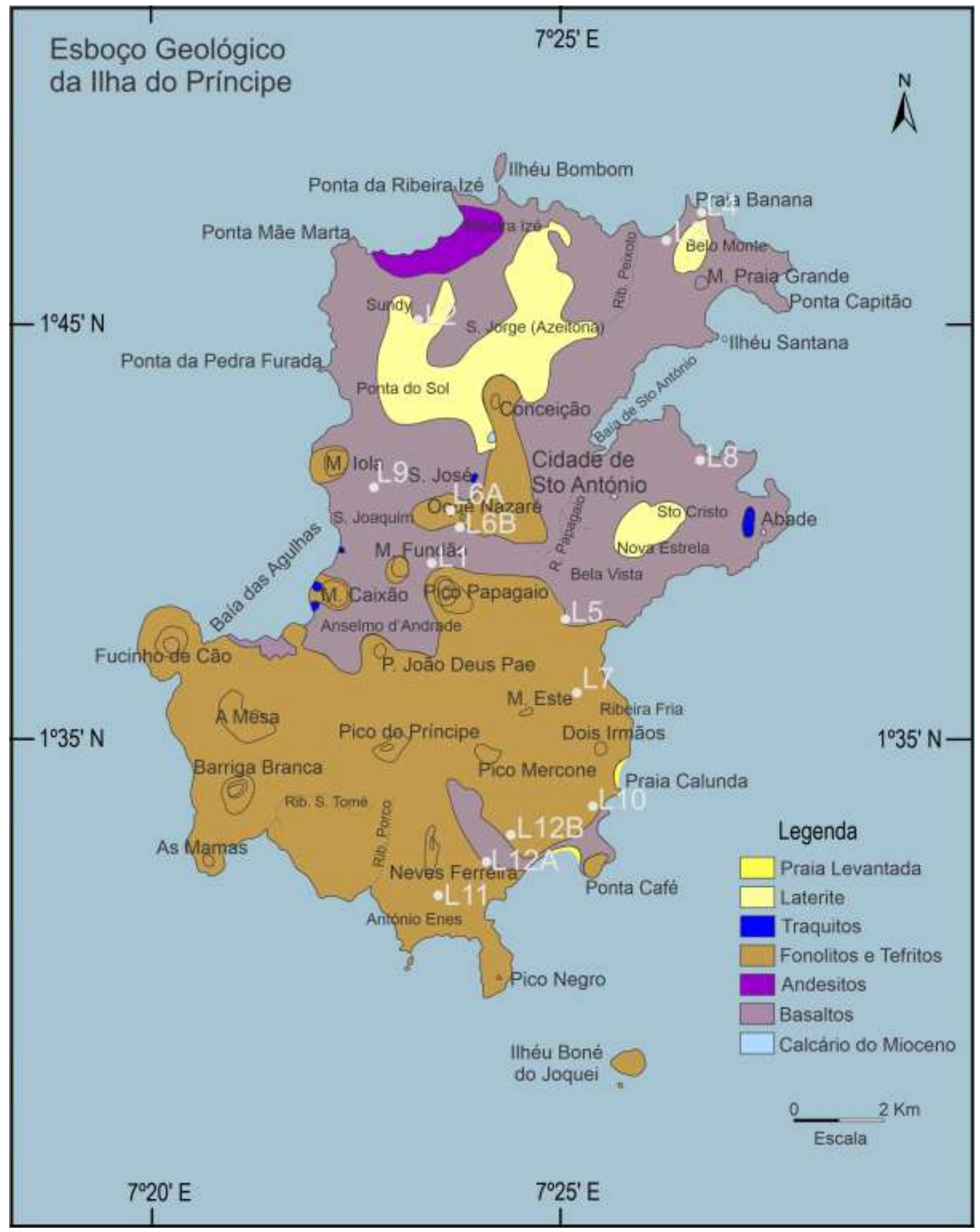

Figura 5: Esboço geológico e localização dos pontos amostrais da llha do Príncipe. Adaptado de Neiva (1956b). 


\section{RESULTADOS E DISCUSSÕES}

\subsection{Petrografia das amostras coletadas}

A presente descrição petrográfica engloba todas as amostras coletadas no campo, pelo autor, nas três ilhas. Vale ressaltar que as análises modais foram baseadas em estimativas visuais dos minerais presentes na rocha, e a nomenclatura foi atribuída pela composição e percentagem mineral. As análises modais constam nas tabelas 4,5 e 6 do apêndice $A$.

\subsubsection{Ilha de Ano-Bom}

Neste trabalho pode-se obter maiores informações sobre a litologia presente na ilha, composição mineralógica e relações texturais das rochas. Em escala de afloramento foram observados numerosos diques intrudindo sedimentos arenosos, principalmente na região oeste-sudeste, nas proximidades de Aual. As rochas mais comuns são basálticas, afaníticas, de coloração cinza escura, ocorrendo traquito em blocos de matação de tamanhos variados e bem alterados.

\section{Traquito (AB3-PF)}

Rocha holocristalina porfirítica, bastante alterada, apresentando matriz finamédia, composta fundamentalmente por feldspatos alcalinos e feldspatoides. Ocorrem também biotita e opacos, tendo epídoto como acessório (Tabela 4).

O feldspato alcalino compõe a matriz rochosa $(0,1-0,2 \mathrm{~mm})$, com evidências de orientação de fluxo, gerando a textura traquítica. Exibe maclas polissintéticas, com extinção ondulante, denotando deformação mineral pós cristalização. A nefelina surge como macrocristais $(0,75-1,5 \mathrm{~mm})$, normalmente cúbicos, bastante alterados, apresentando ocasionalmente extinção ondulante (Figura 6a). Observa-se pouca ocorrência de microcristais na matriz.

A biotita ocorre como macrocristais alterados, bem como microcristais nos interstícios dos feldspatos (Figura 6b), comumente substituída na borda por opacos. Os opacos estão caoticamente distribuídos nos interstícios dos feldspatos. Também aparecem como microcristais inclusos na biotita, e outrossim como aglomerados. $\mathrm{O}$ epídoto está intimamente associado a biotita. 


\section{Basanito (AB4-AW)}

Rocha holocristalina porfirítica, muito fina a fina, composta essencialmente por piroxênio, plagioclásio, olivina, opacos e vidro (Tabela 4).

O piroxênio majoritariamente microcristalino constitui a matriz $(0,1-0,25$ $\mathrm{mm}$ ). Ocorre baixo percentual de macrocristais subeuédricos a anédricos, maclados e zonados, centro esverdeado e borda acastanhada, denotando extinção ondulante.

As ripas microcristalinas de plagioclásio apresentam maclas polissintéticas, com orientação de fluxo e terminação em rabo de andorinha (Figura 6c).

A olivina ocorre como macrocristais $(0,5-1,5 \mathrm{~mm})$, subeuédricos a arredondados, cloritizados nas bordas e fraturas, e são microcristalinos na matriz.

Os opacos estão distribuídos como microcristais de tamanho e forma variada, formando pequenos aglomerados, associados ao vidro intersticial, podendo serem também observados macrocristais cúbicos.

\section{Olivina basalto (AB1-PC/AB2-LP)}

Rocha hipocristalina, de textura porfirítica, matriz muito fina, composta por plagioclásio, olivina, piroxênio, opacos, vidro, bem como biotita, zeólita, apatita e espinélio, em baixa percentagem como minerais acessórios (Tabela 4).

O plagioclásio microcristalino $(0,1-0,6 \mathrm{~mm})$, ripiforme, com aspecto de líquido congelado, não cristalizado (Figura 6d), está associado às agulhas de apatita acicular, opacos, vidro e piroxênio, indiciando um resfriamento rápido da rocha.

Os macrocristais de olivina euédricos a subeuédricos, alterados e fraturados, apresentando borda de reação nítida. Ocorre como microcristais na matriz. Observase também um xenólito olivínico recristalizado, com feições de reabsorção (Figura $6 d)$.

Os macrocristais $(0,5-2,5 \mathrm{~mm})$ de piroxênios ortorrômbicos e monoclínicos subeuédricos apresentam borda de reação. Eles não apresentam maclas, nem zoneamento, sendo perceptíveis cristais recristalizados na borda, mantendo o núcleo preservado.

Os opacos denotam formato cúbico e arredondado, ocasionalmente nas bordas dos macrocristais de piroxênio e muitas vezes como agregados. O vidro com aspecto devitrificado é intersticial, enquanto que a biotita ocorre como mineral de alteração e a zeólita como preenchimento vesicular. $O$ espinélio de cor marrom avermelhado é raro, ocorre como acessório. 


\section{Basalto (AB6-PP/AB7-AB/AB8-MA)}

Rocha hipocristalina, textura porfirítica muito fina a fina, de matriz vítrea, composta por plagioclásio, piroxênio, olivina, opacos e vidro (Tabela 4).

O plagioclásio surge apenas como microcristal $(0,01-0,05 \mathrm{~mm})$, denotando orientação de fluxo, maclas polissintéticas e ocasionalmente com aspecto de liquído não cristalizado. Associados ao piroxênio, opacos e vidro nos interstícios formam a matriz.

Os macrocristais $(0,5-3,0 \mathrm{~mm})$ de piroxênio (augita) são euédricos a subeuédricos, denotando bordas de reação, zonados e maclados, com inclusões de opacos, por vezes englobando o plagioclásio, formando a textura ofítica da rocha. Observa-se a ocorrência de interdigitação de piroxênio em olivina e, outrossim, englobado por este e presume-se ser um provável antecristal ou mesmo xenocristal. É visível um megacristal fraturado com o centro levemente esverdeado, pressupondo mudança composicional (Figura 6e). A olivina macrocristalina (0,5 $1,2 \mathrm{~mm}$ ), aparece por vezes arredondada e fraturada, alterada na borda por iddingsita de coloração laranja-avermelhada.

Os opacos estão distribuídos regularmente pela matriz de tamanhos e formas variadas, majoritariamente microcristalinos, por vezes agrupados entre si e inclusos nos macrocristais. O vidro, por sua vez, é intersticial e com aspecto devitrificado. A zeólita ocorre como material de preenchimento vesicular com extinção em leque.

\section{Picro-basalto (AB5-MB/AB9-PC)}

Rocha hipocristalina fina, de textura porfirítica, composta essencialmente por olivina, piroxênio, plagioclásio, com certa quantidade de vidro e opacos. Ocorrem baixos percentuais de clorita, zeólita, carbonato e espinélio (Tabela 4).

A olivina ocorre como macrocristal subeuédrico a arredondado, fraturado, com aparente borda de reação. Nas fraturas há ocorrência de cloritização, sendo visíveis os pseudomorfos olivínicos, substituidos completamente por clorita, bem como pela iddingsita, principalmente nos macrocristais.

É perceptível tanto a presença de ortopiroxênio, quanto de clinopiroxênio, estando este último como microcristais compondo a matriz. O ortopiroxênio apresenta-se como macrocristal anguloso $(0,5-1,5 \mathrm{~mm})$, corroído e substituído na borda, denotando desequilíbrio composicional com a componente da matriz e com 
núcleo preservado (Figura 6f). Observa-se também na mesma amostra sua total recristalização, indicando um desequilíbrio com o magma. As pequenas ripas de plagioclásio justapostas ao vidro intersticial e aos opacos constituem a matriz $(0,1-$ $0,3 \mathrm{~mm}$ ) fina da rocha. O vidro apresenta aspecto devitrificado, enquanto a zeólita, espinélio e carbonato são minerais pós magmáticos.
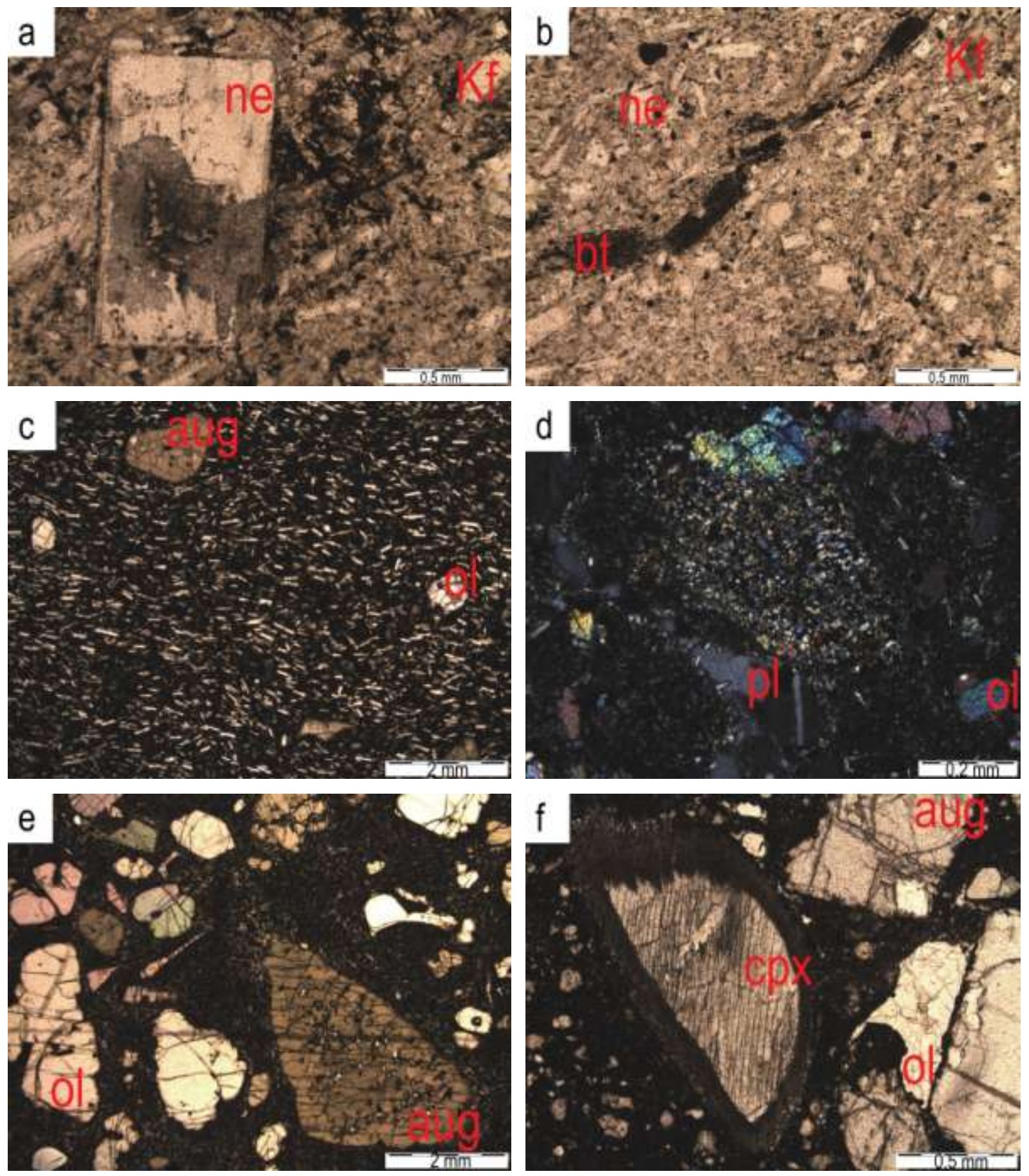

Figura 6: Fotomicrografia dos litotipos da llha de Ano- Bom.

$a, b=$ AB3-PF) Traquito de matriz feldspática, com megacristal de nefelina alterada e cristais de biotita seguindo o fluxo textural (nicóis paralelos); $c=A B 4-A W$ ) Basanito com textura de fluxo 
marcada pela orientação de ripas de plagioclásio, presença de macrocristais de augita com borda de reação e olivina preenchida por clorita nas fraturas (nicóis paralelos); $d=A B 1-P C$ ) Olivina basalto de matriz feldspática com aspecto de líquido não cristalizado evidenciando xenólito olivínico recristalizado, com feições de reabsorção (nicóis cruzados); e = AB7-AB) Basalto com megacristal de augita com borda de reação cristalizando plagioclásio e opaco, com o núcleo esverdeado e olivina bastante fraturada (nicóis paralelos); $f=A B 9-P C$ ) Picro-basalto exibindo xenocristal de ortopiroxênio anguloso, com borda de reação, sendo corroído e substituído (nicóis paralelos). Legenda: aug=augita; ol=olivina; pl=plagioclásio; ne=nefelina; opx=ortopiroxênio; bt=biotita; kf=k-feldspato.

\subsubsection{Ilha de São Tomé}

A Ilha de São Tomé apresenta uma variedade litológica apreciável, com predominância de rochas basálticas, mas com ocorrência importante de rochas félsicas como traquitos e fonolitos. Neste item a petrografia será abordada segundo as quatro unidades vulcano-estratigráficas definidas por Caldeira et al. (2003) e Munhá et al. (2007).

\section{Formação Vulcânica Ilhéu das Cabras (FVIC)}

Os afloramentos desta unidade são marcados por maciços rochosos consistentes, de coloração cinza clara, constituindo dois montes ligados entre si. É visível, em escala de afloramento, um conjunto de fraturas preenchidas por material silicoso, bem como a presença de numerosos blocos de matacão.

\section{Traquito (P12A-IC/ P12B-IC)}

Rocha holocristalina fina-média, de textura porfirítica com predomínio de feldspato alcalino, baixas proporções de feldspatoide, opacos e biotita (Tabela 5).

Os macrocristais de feldspatos alcalinos apresentam geminação polissintética. Microcristais ripiformes $(0,025-0,1 \mathrm{~mm})$ formam a matriz fina-média, exibindo orientação de fluxo (Figura 7a), originando a textura traquítica. Associados aos opacos constituem a textura glomeroporfirítica (Figura $7 \mathrm{~b}$ ). Alguns macrocristais tabulares e prismáticos, sericitizados e bastante alterados no núcleo, exibem extinção ondulante, com inclusão de opacos e epídoto.

O feldspatoide (nefelina), pouco abundante, apresenta-se levemente alterado e ocasionalmente com extinção ondulante.

A biotita surge como macrocristais $(0,25-1,5 \mathrm{~mm})$ tabulares alongados $\mathrm{e}$ alterados, englobando cristais de feldspato (Figura 7a). 
Os opacos estão distribuídos na matriz como minerais microcristalinos primários, cúbicos e arredondados, bem como secundários, de substituição associados a biotita.

\section{Complexo Vulcânico Mizambú (CVM)}

As duas rochas constituintes desta unidade (P1 e P2) foram coletadas nas regiões de Aguá Izé e Alto D'ouro. Possuem coloração cinza escura, de textura afanítica a fanerítica muito fina, pouco alterada, apresentando cristais de olivina e piroxênio visível ao olho nu.

\section{Olivina basalto (P2-AD)}

Rocha holocristalina com textura porfirítica, formada em grande parte por plagioclásio, acompanhado por olivina, piroxênio, opacos e vidro (Tabela 5).

O plagioclásio microcristalino ripiforme compõe a matriz da rocha e em alguns casos ocorre como macrocristais tabulares alongados (labradorita-An$n_{54}$ ) de tamanhos diversificados. Os microcristais marcam a orientação de fluxo na matriz e se encontram associados aos opacos e ao vidro intersticial. Os megacristais aparecem alterados e exibem borda de reação, crescimento concêntrico e inclusões de opacos. A amostra contém um xenólito félsico alterado, formado por aglomerados de pequenos cristais recristalizados de plagioclásio, com inclusão de pseudomorfo de olivina (Figura 7d).

Os macrocristais de olivina, subeuédricas à arredondados, encontram-se alterados e preenchidos nas bordas e fraturas por clorita. Ocasionalmente aparecem substituídos por clorita na totalidade (pseudomorfos de olivina) com opacos associados. Os microcristais compõem a matriz.

O piroxênio augítico microcristalino também compõe a matriz. Os macrocristais (titano-augita) euédricos a subeuédricos, zonados, maclados, com extinção concêntrica ondulante, estão, em algumas circunstâncias, englobando cristais ripiformes de plagioclásio, gerando a textura ofítica. Os megacristais com borda de reação englobam os pseudomorfos de olivina (Figura 7c).

Os opacos, por sua vez, ocorrem como minerais primários na matriz, bem como minerais secundários. Estes estão associados a clorita como mineral de substituição na borda da olivina e do piroxênio, ou em agregados cumuláticos 
relacionados ao vidro devitrificado. Os microcristais variam entre 0,05 e 0,25 mm, enquanto os macrocristais entre 0,5 e $1,5 \mathrm{~mm}$.

\section{Basalto (P1-AI)}

Rocha holocristalina com textura porfirítica, de matriz muito fina a fina, em que há predominio de plagioclásio, acompanhado por piroxênio e olivina (Tabela 5).

Microcristais de plagioclásio ripiformes expõem a macla polissintética e alguns macrocristais apresentam borda com extinção distinta do núcleo. As ripas microcristalinas associadas ao vidro e opacos formam a matriz da rocha, juntamente com microcristais de augita e olivina.

Os macrocristais de olivina, euédricos à subeuédricos apresentam-se fraturados e alterados tanto na borda quanto no centro, por um material de coloração laranja-avermelhado, pressupondo percolação de água e reação química, por vezes consumida para formar piroxênio.

Os piroxênios são euédricos a subeuédricos, com maclas e zonamento. É visível a presença de orto e clinopiroxênio, sendo que este último forma textura intergranular, com crescimento entre as ripas alongadas de plagioclásio. Por vezes ocorrem aglomerados de macrocristais de clinopiroxênio, associados à olivina e opacos formando textura glomeroporfirítica. Os microcristais variam entre 0,1 e 0,2 $\mathrm{mm}$, enquanto os macrocristais variam entre 0,5 e 1,2 $\mathrm{mm}$.

\section{Complexo Vulcânico Ribeira Afonso (CVRA)}

Aos principais litotipos dessa unidade, bastante variada, associam-se agora o picro-basalto e olivina diabásio (classificado no TAS como basanito), como rochas afaníticas de cor cinza escura, encontrados, respectivamente, nas regiões de Dona Augusta e Ribeira Peixe. Em escala de afloramento, na região litorânea da ilha de São Tomé, foram observadas localmente estruturas típicas, tais como disjunções colunares com características de resfriamento rápido, análogas ao modelo de resfriamento que ocorre nas dorsais meso-oceânicas e, também estruturas de pillowlavas.

\section{Basalto (P3-PP)}

Rocha hipocristalina com textura porfirítica, de matriz vítrea muito fina, bastante alterada. Além de vidro, aparecem olivina, piroxênio, opacos e plagioclásio (Tabela 5). 
A olivina compreende desde micro a megacristais $(0,25-0,5 \mathrm{~mm})$, euédricos a anédricos. Os macrocristais apresentam borda alterada por iddingsita de cor laranja-avermelhada. Ocorrem também pseudomorfos de olivina, substituída por iddingsita. Os microcristais $(0,001-0,002)$ de olivina compõem a matriz muito fina, associados a vidro, piroxênio e opacos.

Macrocristais de piroxênio são pouco expressivos, bastante fraturados e com bordas de reação. Piroxênio microcristalino encontra-se na matriz. Plagioclásio surge como massa líquida não cristalizada, e vidro se apresenta com características de devitrificação, associado a opacos.

\section{Picro-basalto (P9-DA)}

Rocha holocristalina muito fina, com textura porfirítica, formada principalmente por plagioclásio e piroxênio, acompanhados de olivina e minerais opacos, além de certa quantidade de vidro (Tabela 5).

O plagioclásio microcristalino ripiforme apresenta terminação em rabo de andorinha e denota aspecto de líquido não cristalizado. Está associado a piroxênio e opacos, e vidro ocorre nos interstícios, compondo a matriz. Nesta rocha não se observaram macrocristais de plagioclásio.

O piroxênio ocorre tanto como microcristal na matriz, quanto como macrocristal. Estes últimos são euédricos à subeuédricos, maclados, zonados e englobando plagioclásio formando a textura ofítica (Figura 7e). Eles apresentam borda de reação, com opacos e plagioclásio associados, possivelmente interagindo com líquido da matriz, indicando que provavelmente não se formaram ao mesmo tempo que os minerais da matriz. Pode tratar-se de antecristais ou xenocristais (Figura 7e).

A olivina ocorre como macrocristais, euédricos a arredondados, comumente cloritizados em bordas e fraturas, com inclusões de opacos e em alguns casos completamente substituídos por clorita.

Os opacos, por sua vez, estão distribuídos regularmente como microcristais cúbicos a arredondados, e surgem tanto como mineral primário na matriz, quanto mineral de substituição secundário.

O vidro apresenta aspecto devitrificado e forma textura intersertal, enquanto zeólita é material de preenchimento de vesículas e ostenta extinção ondulante. 
Microcristais variam entre 0,005 e $0,01 \mathrm{~mm}$, enquanto os macrocristais variam entre 0,5 e $2,3 \mathrm{~mm}$.

\section{Basanito (P11-RP)}

Rocha holocristalina de matriz média-grossa, textura glomeroporfirítica, composta por piroxênio, plagioclásio e olivina. Os opacos e vidro aparecem subsidiariamente (Tabela 5).

Os cristais subeuédricos de piroxênio ocorrem em aglomerados cumuláticos distribuídos regularmente na rocha, sendo rara a ocorrência como macrocristal, que se apresenta zonado e comumente associado aos macrocristais opacos, visivelmente englobado por olivina. Observa-se também um xenólito recristalizado formado provavelmente por microcristais ferromagnesiano (olivina e piroxênio), figura $7 f$.

As ripas alongadas de plagioclásio variando entre 0,1 e 0,25 mm, sem orientação preferencial, ostentam maclas polissintéticas, com terminação em rabo de andorinha (Figura 7f).

A olivina ocorre como macrocristais de dimensões entre 0,3 e 0,6 mm, e formas variadas, desde euédricas a arredondadas, normalmente fraturadas, não sendo perceptíveis preenchimentos, com inclusões de opacos, bem como englobando plagioclásio e piroxênio.

Os opacos surgem tanto como macrocristais, quanto como microcristais cúbicos e ocasionalmente como agregados cumuláticos. O vidro intersticial ao plagioclásio, associado ao piroxênio e opacos, compõem a matriz. A apatita surge como acessório incluso no plagioclásio.

\section{Complexo Vulcânico São Tomé (CVST)}

Os afloramentos representativos deste complexo ocorrem nas regiões de Guadalupe, Morro de Micoló e Praia Piscina, a NNE e S da ilha. As amostras foram coletadas em blocos encaixados no interior de edifícios piroclásticos de granulação heterogênea, aglutinados por uma matriz de lapilli. As rochas são afaníticas, de coloração cinza escura, e apresentam em alguns casos vesículas preenchidas por material silicoso. 


\section{Basalto (P5-DN)}

Rocha hipocristalina de textura porfirítica, de granulação fina a muito fina, composta principalmente por plagioclásio, acompanhado de olivina e piroxênio, além de vidro e minerais opacos (Tabela 5).

Os microcristais ripiformes de plagioclásio caracterizam a matriz da rocha, de granulação fina a muito fina. As ripas não apresentam orientação preferencial e em alguns casos surgem com terminação em rabo de andorinha.

A olivina é subeuédrica à arredondada, ocorrendo na matriz como microcristais, mas também surge como macrocristais fraturados e preenchidos por clorita.

O piroxênio augítico está levemente fraturado, apresentando-se maclado, zonado e com alguns cristais alterados nas bordas por plagioclásio.

Vidro devitrificado, intersticial às ripas de plagioclásio, ocorre com extinção ondulante. Clorita e carbonatos são minerais pós magmáticos. Os cristais da matriz variam entre 0,05 e $0,1 \mathrm{~mm}$, enquanto que os macrocristais variam entre 0,2 e 1,6 $\mathrm{mm}$.

\section{Tefrito (P7-SN/P8-PA)}

Estas duas rochas hipocristalinas apresentam textura glomeroporfirítica, muito fina a fina, e são muito semelhantes na composição mineralógica, formada por plagioclásio, piroxênio, opacos, vidro e olivina (Tabela 5).

O plagioclásio microcristalino ripiforme, sem orientação preferencial, compõe a matriz associado ao piroxênio, vidro e opacos.

O piroxênio microcristalino na matriz, euédrico à subeuédrico, surge também como macrocristais de borda marrom-acastanhada e núcleo esverdeado (Figura 7h), exibindo maclas, zoneamento, com inclusão de plagioclásio, gerando a textura ofítica. Alguns macrocristais esverdeados, com o núcleo cominuído, aparecem reagindo com a matriz (Figura $7 \mathrm{~h}$ ).

A olivina surge como macrocristais alterados na borda por iddingsita e fraturas preenchidas por clorita. Minerais opacos têm tamanhos e formas variadas, por vezes formando pequenos aglomerados de cristais, normalmente dispersos e inclusos em piroxênio. Vidro intersticial encontra-se associado aos minerais da matriz. Os microcristais variam entre 0,01 e 0,05 mm, e os macrocristais entre 0,25 e $1,0 \mathrm{~mm}$. 


\section{Basanito (P4-CG/P6-PM/P10-PP)}

Estas três rochas hipocristalinas muito finas, com textura porfirítica a traquitoide, são compostas por plagioclásio, piroxênio, olivina, opacos e vidro intersticial (Tabela 5).

O plagioclásio microcristalino, nas amostras $\mathrm{P} 4$ e $\mathrm{P} 10$, aparece como ripas alongadas, formando orientação de fluxo, e não há vestígios de macrocristais na rocha. Por outro lado, na amostra P6, ele ocorre como líquido feldspático não cristalizado.

Os macrocristais zonados e maclados de piroxênio apresentam-se com textura sieve. Uma boa parte dos cristais apresenta estrutura interna esquelética, com borda amarela-acastanhada e núcleo esverdeado (Figura $7 \mathrm{~g}$ ), denotando mudança composicional. Em alguns casos verifica-se reação com olivina na borda, indicando crescimento continuado. Os microcristais constituem a matriz juntamente com plagioclásio, opacos e vidro intersticial.

Os macrocristais de olivina, subeuédricos a anédricos, por sua vez encontram-se alterados na borda e nas fraturas por uma massa marrom amarelada (Figura $7 \mathrm{~g}$ ), indiciando percolação de fluido.

Os minerais opacos microcristalinos, cúbicos a arredondados, inclusos nos macrocristais de piroxênio e olivina, por vezes, aparecem aglomerados. O vidro apresenta-se devitrificado, com textura intersertal. Zeólita aparece com extinção ondulante, fruto do preenchimento de vesículas. Os macrocristais variam entre 0,25 e $1,3 \mathrm{~mm}$, enquanto os microcristais variam entre 0,01 e $0,05 \mathrm{~mm}$.
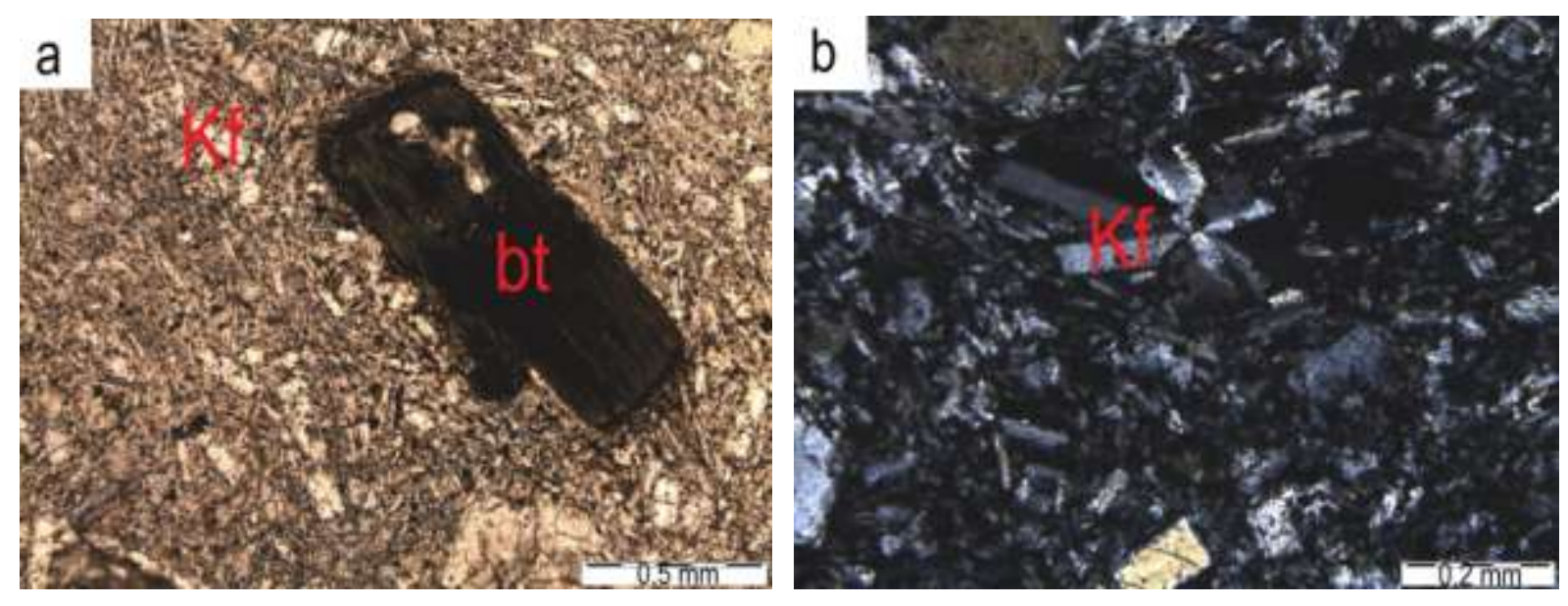

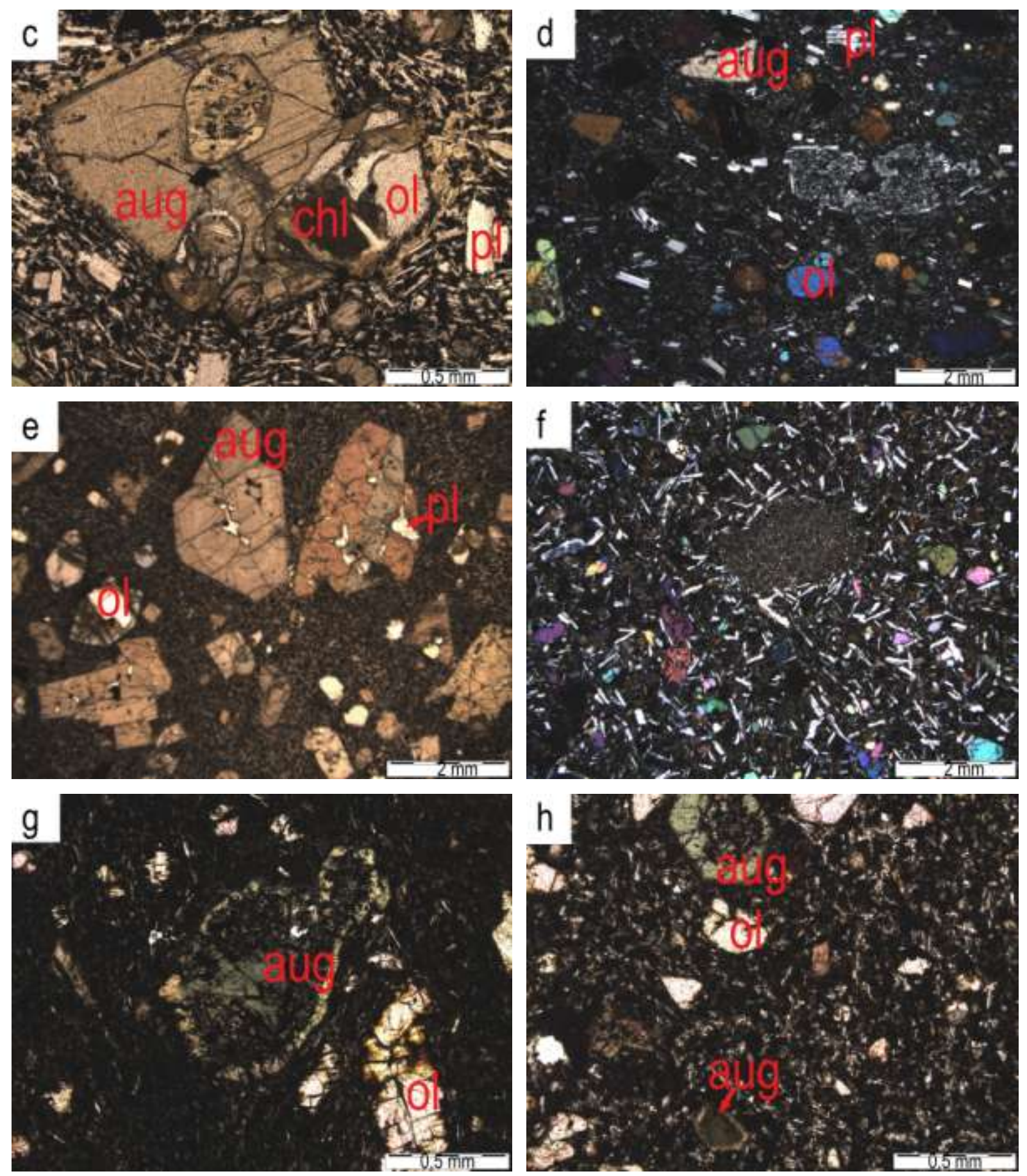

Figura 7: Fotomicrografia dos litotipos da llha de São Tomé.

$a, b=P 12 A-I C)$ Traquito alterado de matriz feldspática orientada, exibindo megacristal de biotita envolvendo feldspato (a-nicóis paralelos); $c, d=P 2-A D$ ) Olivina basalto de matriz feldspática com orientação de fluxo, ostentando megacristal de augita, com borda de reação e inclusão de pseudomorfo arredondado de olivina substituída pela clorita, exaltando xenólito félsico de microcristais de plagioclásio (d-nicóis cruzados); e = P9-DA) Picro-basalto de matriz muito fina, exaltando megacristais de augita zonada e geminada, englobando ripas de feldspato, formando a textura ofítica e presença de macrocristais de olivina sendo alterada pela clorita (nicóis paralelos); $f=$ P11-RP) Basanito evidenciando olivina e piroxênio levemente alterados, exibindo xenólito recristalizado (nicóis cruzados); $\mathrm{g}=\mathrm{P} 10-\mathrm{PP}$ ) Basanito hipocristalino com megacristal de augita com 
estrutura esquelética (nicóis paralelos); $\mathrm{h}=\mathrm{P} 8-\mathrm{PA}$ ) Tefrito com macrocristais de augita com borda acastanhada e centro esverdeado, denotando reação do núcleo (nicóis paralelos). Legenda: aug=augita; ol=olivina; bt=biotita; kf=k-feldspato; pl=plagioclásio; chl=clorita.

\subsubsection{Ilha do Príncipe}

Esta ilha, que carece de mapeamento aprofundado para a composição do mapa geológico, apresenta variedades litológicas quimicamente bastante diversificadas, tanto máficas quanto félsicas. Suas rochas são majoritariamente afaníticas (olivina basalto, fonólito e fonotefrito), mas aparecem também alguns litotipos faneríticos de granulação fina a média (basanito, tefrifonolito $e$ traquifonolito), de cores variadas, como cinza escuro, verde musgo e cinza claro.

\section{Olivina basalto (L3-PC/L4-PB/L8-PE)}

Estas três rochas hipocristalinas, com textura porfirítica, são formadas por plagioclásio, piroxênio, olivina, opaco, além de baixa quantidade de vidro e apatita (Tabela 6).

Os microcristais ripiformes de plagioclásio, com tamanho variável entre 0,01 e 0,05 mm, não apresentam orientação preferencial e por vezes ocorrem como massa líquida não cristalizada, associada ao vidro intersticial na matriz.

O piroxênio augítico microcristalino é mais frequente na matriz, mas também surge como macrocristais subeuédricos, com macla e zoneamento, com inclusões de agulhas finas de apatita (Figura 8a). Os macrocristais de olivina são preenchidos por clorita nas bordas e fraturas, e alguns são reconhecidos como pseudomorfos. Os macrocristais apresentam tamanhos entre 0,1 e $0,8 \mathrm{~mm}$.

Os minerais opacos exibem formato cúbico à anguloso, e são distribuídos regularmente na matriz da rocha, formando pequenos agregados. Por vezes aparecem como macrocristais (Figura 8a).

\section{Basanito (L2-RS/L5-TV)}

As duas rochas holocristalinas de textura glomeroporfirítica, inequigranular, são constituídas principalmente por piroxênio, associado a olivina, plagioclásio, opacos, vidro e clorita (Tabela 6).

Os megacristais de augita maclados, fortemente zonados e geminados (Figura 8d), surgem ocasionalmente como aglomerados, euédricos a subeuédricos, e apresentam inclusões de opacos (Figura 8b). 
A olivina aparece como macrocristais, fortemente alterados na borda e fraturas por clorita, de cor verde-amarelada, sendo observável a sua substituição parcial (Figura 8c). Alguns pseudomorfos com extinção radial, associados aos minerais opacos também são observados.

O plagioclásio bem formado exibe macla polissintética, apresentando ripas com terminação em rabo de andorinha (Figura 8b). Associado ao vidro intersticial constitui a matriz da rocha. Alguns macrocristais mostram-se esburacados e com pequenas inclusões de apatita e opacos.

Minerais opacos encontram-se em pequenos aglomerados, distribuídos na matriz, surgindo também como inclusões nos macrocristais. Vidro divitrificado, gera uma massa anómala de estágios distintos, na matriz microcristalina $(0,2-0,5 \mathrm{~mm})$, que exibe textura glomeroporfirítica determinada pelos macrocristais máficos $(0,7-$ $3,0 \mathrm{~mm})$.

\section{Fonotefrito (L1-ST)}

Rocha hipocristalina fina, de textura porfirítica, em que predomina plagioclásio, acompanhado de anfibólio, piroxênio e opacos. Vidro também aparece em quantidade razoável (Tabela 6).

O plagioclásio microcristalino $(0,1-0,6 \mathrm{~mm})$ ripiforme na matriz, forma ocasionalmente terminação em rabo de andorinha, e apresenta por vezes aspecto de congelamento de líquido não cristalizado.

Os macrocristais de piroxênio augítico $(0,8-1,5 \mathrm{~mm})$ são maclados e fortemente zonados (Figura 8e). Apresentam-se alterados e corroídos na borda e no núcleo. Anfibólio alcalino (kaersutita) aparece em macrocristais, geminado e denotando borda de reação com a matriz (Figura 8e).

Olivina surge englobada por megacristal de augita e sendo substituída por clorita, surgindo agregados de argilominerais com extinção em leque. $O$ vidro devitrificado, de coloração marrom, encontra-se associado ao plagioclásio nos seus interstícios. Os minerais opacos estão distribuídos na matriz, por vezes agrupados e nas bordas do anfibólio, como mineral de substituição.

\section{Fonolito (L6A-PP/L6B-PP/L10-RF)}

Essas três rochas são muito semelhantes, hipocristalinas com textura traquitoide, porfirítica, muito fina a fina. Predominam feldspatos alcalinos, associados 
a nefelina, aegirina e anfibólio alcalino. Pequena quantidade de vidro intersticial também é observada (Tabela 6).

Os macrocristais de feldspato alcalino encontram-se alterados, com extinção ondulante e formam uma massa microcristalina na matriz, com orientação de fluxo e com vidro nos seus interstícios. A nefelina ocorre como macrocristais, possivelmente xenocristais, com extinção ondulante e borda de reação formada por aegirina e opacos. Na matriz, é possível que existam microcristais de leucita.

A aegirina, esverdeada, microcristalina na matriz, forma pequenos aglomerados (Figura 8f), associados aos feldspatoides nas bordas. $O$ anfibólio pleocróico surge como macrocristais, exibindo borda de reação coroada pela aegirina (Figura 8f), e com inclusão de augita e opacos no núcleo. Titanita também ocorre como macrocristal associada aos opacos. Os microcristais variam entre 0,01 e 0,06 mm, enquanto os macrocristais entre 0,25 e 2,1 mm.

\section{Tefrifonolito (L7-TB/L9-SJ)}

Essas duas rochas holocristalinas de matriz fina, ostentam uma textura traquitoide, com predominância absoluta de feldspato alcalino, acompanhado de aegirina e possivelmente sodalita (Tabela 6).

O feldspato microcristalino ripiforme exibe orientação preferencial, com características de resfriamento rápido, compondo a matriz associado à sodalita. $\mathrm{A}$ aegirina ocorre como microcristais distribuídos na matriz, aparecendo também como aglomerados cumuláticos (Figura $8 \mathrm{~g}$ ), denotando textura de reação, circundando um pseudomorfo de mineral difícil de distinguir.

A analcima surge como pequenos cristais prismáticos nos interstícios dos feldspatos, incolores e isotrópicos a nicóis cruzados. Alguns macrocristais de nefelina parecem estar reagindo com piroxênios da matriz, sendo consumidos por estes. É visível a inclusão de cristais de titanita em nefelina (Figura 9g). Os microcristais variam entre 0,01 e $0,02 \mathrm{~mm}$, enquanto os macrocristais variam entre 0,2 e $2,0 \mathrm{~mm}$.

\section{Traquifonolito (L12A-RF/L12B-RF)}

Duas partes da mesma amostra foram analizados. Trata-se de uma rocha holocristalina muito fina a fina, de textura traquitóide, composta por feldspato alcalino, piroxênio, nefelina e anfibólio (Tabela 6). 
O feldspato microcristalino, com ripas alongadas e orientação preferencial define a textura traquitoide, associado aos microcristais de aegirina na matriz, que constituem pequenos agregados cumuláticos, circundando os cristais de feldspato. Os macrocristais variam entre 0,01 e 0,05 mm.

Os microcristais de aegirina, com hábito prismático alongado, distribuídos de forma homogênica, constituem pequenos agregados cumuláticos, circundando o feldspato. A aegirina também forma macro e megacristais subeuédricos (Figura 8h), com aspecto rugoso e por vezes com núcleo acastanhado, com inclusões de opacos.

A nefelina surge como macro e megacristais tabulares, com extinção ondulante, demonstrando não estar em equilíbrio com o líquido da matriz. Em suas fraturas ocorrem microcristais de egirina. A titanita ocorre como micro e macrocristais normalmente euédricos, raramente como megacristal, associado aos piroxênios. O carbonato é provavelmente pós-magmático.

Os macrocristais alterados de anfibólio estão envoltos em uma coroa de borda de reação, normalmente associada à egirina, que pode os estar substituindo. As dimensões dos macrocristais variam entre 0,5 e 2,2 mm.

\section{Traquiandesito (L11-PP)}

Rocha holocristalina de matriz fina, textura traquitoide, composta essencialmente por feldspato alcalino, acompanhado de anfibólio, piroxênio e opacos (Tabela 6).

O feldspato microcristalino apresenta uma textura de fluxo determinada pela orientação preferencial das ripas.

O anfibólio macrocristalino por vezes apresenta borda de reação, denotando desequilíbrio com o líquido da matriz rochosa, estando a ser consumido para formar aegirina-augita e opacos (Figura 8j).

A aegirina-augita macrocristalina, euédrica a subeuédrica, zonada, exibindo núcleo acastanhado e borda esverdeada (Figura 8j), apresenta pequenas inclusões de minerais opacos, e ocasionalmente forma pequenos agregados de cristais.

Os macrocristais de titanita subeuédricos estão normalmente associados aos opacos. Os microcristais opacos estão associados aos feldspatos na matriz, surgindo também como macrocristais secundários associados aos minerais máficos. 
Observa-se a presença de xenólitos félsicos (Figura 8i), bastante alterados, incorporando tanto o piroxênio quanto o anfibólio, bem como um xenólito máfico recristalizado em microgrãos de difícil distinção. Os microcristais variam entre 0,01 e $0,04 \mathrm{~mm}$, enquanto que os macrocristais variam entre 0,25 e 1,8 $\mathrm{mm}$.
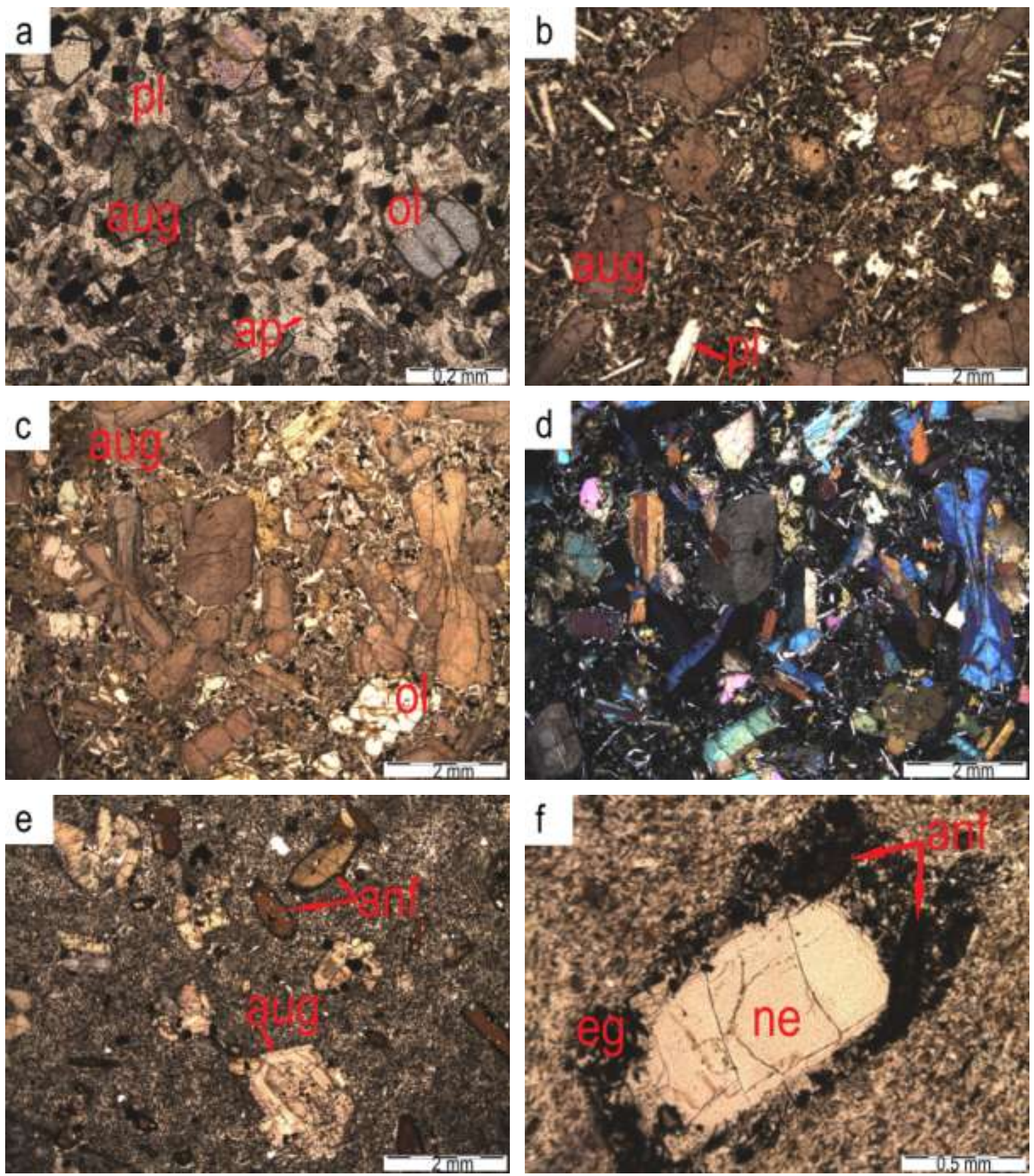

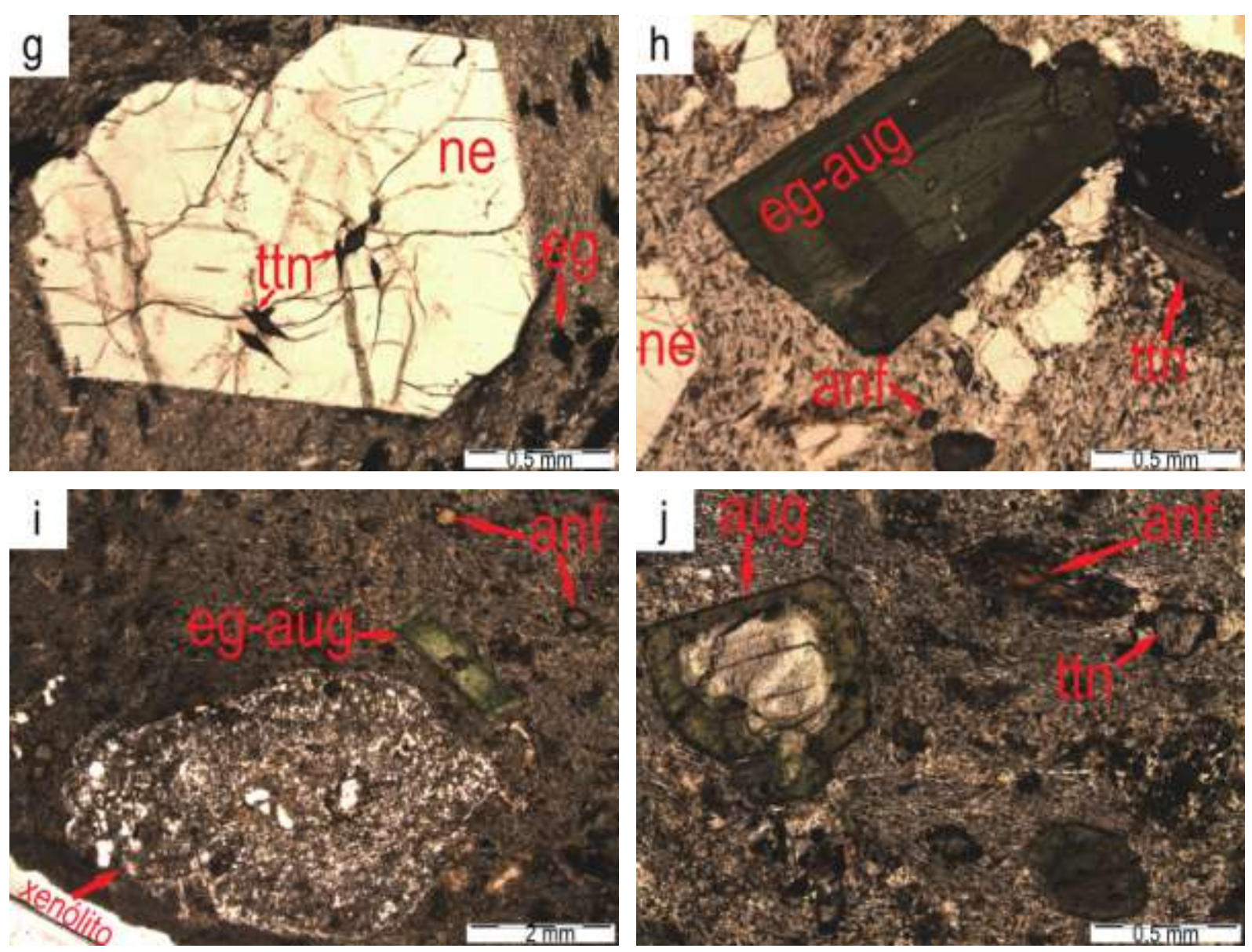

Figura 8: Fotomicrografia dos litotipos da llha do Príncipe.

$\mathrm{a}=$ L3-PC) Olivina basalto de matriz feldspática associada a agulhas de apatita, com presença de macrocristais angulosos de olivina, augita e opacos (nicóis paralelos); b = L5-TV, c, d = L2-RS) Basanito de textura glomeroporfirítica, com megacristais de augita zonada e geminado, com extinção em ampulheta e inclusão de opacos e olivina preenchida por clorita na fratura (d-nicóis cruzados); e = L1-ST) Fonotefrito de matriz feldspática muito fina, com macrocristais de anfibólio geminado envolto a coroa de borda de reação e augita fortemente zonada, alterada na borda e corroída no núcleo (nicóis paralelos); $f=$ L6A-PP) Fonolito de textura traquitoide ostentando megacristal de nefelina alterado na borda por aglomerados de microcristais aciculares de egirina e opacos, associados aos anfibólios (nicóis paralelos); $\mathrm{g}$ = L9-SJ) Tefrifonolito de matriz muito fina com aglomerado de egirina acicular, exibindo megacristal de nefelina com inclusões de titanita (nicóis paralelos); $h=$ L12B-RF) Traquifonolito ostentando megacristal de aegirina-augita com pequenas inclusões e presença de macrocristais de nefelina e titanita associados a aglomerados de microcristais de egirina evidenciando reação entre eles (nicóis paralelos); i, j = L11-PP) Traquiandesito com xenólito félsico muito alterado e macrocristal de aegirina-augita zonada, borda esverdeada e núcleo acastanhado (nicóis paralelos). Legenda: pl=plagioclásio; aug=augita; ol=olivina; ne=nefelina; ttn=titanita; egaug=aegirina-augita; eg=egirina; $\mathrm{kf=k-feldspato;} \mathrm{anf=anfibólio;} \mathrm{ap=apatita.}$

As ilhas que constituem o setor oceânico da Linha Vulcânica dos Camarões são constituidas por diferentes litotipos, como picro-basaltos, basaltos, basanitos, 
tefritos, traquiandesitos, fonotefritos, traquifonolitos, tefrifonolitos, bem como traquitos e fonolitos. Nos litotipos descritos, é percetível a ausência de fonolitos na Ilha Ano-Bom e de traquitos na llha do Príncipe. Dentre os estudos geológicos realizados na llha do Príncipe, Neiva (1956b) na constituição do esboço geológico é o único que faz referência a existência de traquito na ilha. Neste trabalho não há presença de fonolito na descrição feita para as rochas da llha de São Tomé, porém trabalhos anteriores fazem menção à existência deste litotipo na ilha (Caldeira et al., 2003; Caldeira, 2006; Munhá et al., 2007; Lopes, 2010).

As rochas são caracterizadas principalmente pela textura porfirítica e traquítica marcada por duas principais fases minerais. A primeira fase é macrocristalina, marcada pela presença de olivina e clinopiroxênio, nas rochas máficas, e de clinopiroxênio, nefelina e anfibólio nas rochas félsicas. A segunda é microcristalina com presença de olivina, clinopiroxênio, plagioclásio e vidro com carácter interstícial nos litotipos máficos, e nos litotipos félsicos é visível encontrar feldspatos e clinopiroxênio demarcando a textura de fluxo. Opacos são frequentes em quase todas as rochas. A apatita e titanita são os principais acessórios, tendo clorita e iddingsita como principais minerais de substituição. A olivina aparece quase que constantemente alterada pela clorita, no entanto, existe a probabilidade de esta ser um processo de serpentinização, sendo necessárias análises específicas para a sua distinção.

As rochas estudadas apresentam conjuntos de evidências, tais como xenólitos félsicos e máficos, macro e megacristais com borda de reação e zoneamento composicional, núcleos esverdeados com borda acastanhada, megacristais esqueléticos, anfibólios com corona nas rochas intermediárias e diminuição nas rochas evoluídas, indicando mudanças composicionais no líquido magmático.

Constatou-se em picro-basaltos, basaltos e basanitos das três ilhas, a ocorrência de um líquido feldspático não cristalizado, denotando processo de resfriamento rápido, agregado na matriz da rocha. Isto pressupõe a cristalização primária dos macrocristais, e um súbito resfriamento posterior, possivelmente pela rápida ascensão do magma, dada a característica vítrea e intersticial dos minerais. Foram observadas, em escala de afloramento dessas rochas, estruturas de disjunção colunar, que são características de processo de resfriamento rápido das rochas máficas, sendo que essas estruturas favorecem a percolação de água 
meteórica, a qual gera alterações dos minerais presentes, como iddingsita substituindo a olivina.

\subsection{Geoquímica Elemental de Rocha Total}

Como foi indicado na parte introdutória deste trabalho, a geologia do setor oceânico da LVC é a menos conhecida, caso especial das ilhas de Ano-Bom e Príncipe. Nelas, foram realizadas amostragens de reconhecimento que permitiram obter dados petrográficos consistentes. Neste item pretende-se, através de algumas análises químicas de rocha total, verificar a coerência com as análises modais realizadas, controlar a nomenclatura e efetuar algumas considerações a respeito da evolução e diferenciação de magmas precursores.

Cinco amostras representativas de cada uma das três ilhas foram escolhidas para análise química em rocha total. A maioria das rochas coletadas para a presente pesquisa possui natureza próxima de basaltos. Em vista disso, procurou-se incluir, para cada ilha, pelo menos uma amostra de rocha mais evoluída, tal como fonolito ou traquito. Os resultados obtidos nas análises químicas de um conjunto de quinze amostras e uma duplicata para cada ilha, se encontram apresentados na tabela 7 em anexo.

\subsubsection{Nomenclatura e Classificação de Rochas}

A classificação petrográfica efetuada a partir das características microscópicas das rochas analisadas foi sustentada com base nas análises químicas de rocha total, obtida por Fluorescência de raios- $X$.

Os dados das análises químicas dos elementos maiores e menores foram recalculados para 100\% em uma base anidra, a fim de serem utilizados para a construção do diagrama de classificação de rochas vulcânicas de Le Bas et al. (1986), tipo TAS, baseado nos critérios químicos de classificação de rocha "Total Álcalis $\left(\mathrm{Na}_{2} \mathrm{O}_{+} \mathrm{K}_{2} \mathrm{O}\right)$ versus Sílica $\left(\mathrm{SiO}_{2}\right)$ ". A figura 9 representa esse diagrama, onde foi possível identificar imediatamente dois conjuntos de rochas. O primeiro formado por baixos teores de sílica, entre 40 e 50\%, e o segundo com teores mais elevados, entre 55 e 70\%. É evidente um "Daly gap” entre estes dois conjuntos (48 à 63\%), quer na Ilha de Ano-Bom, quer na de São Tomé, o que pode ser resultado da baixa quantidade amostral, porém na literatura é feita referência à existência desta descontinuidade (Cornen and Maury, 1980; Caldeira, 2006). 
Dentre as três ilhas, Príncipe é a que mostra uma continuidade coerente na evolução magmática. Na parte inferior a esquerda, as sequências que englobam as rochas máficas primitivas, básicas e ultrabásicas, tais como picro-basaltos, basaltos e basanitos, enquanto que na parte superior direita aparecem termos félsicos mais evoluídos, tais como fonolitos e traquitos.

Em uma das rochas da llha do Príncipe, definida como traquiandesito pela sua composição mineralógica, observa-se na figura que o percentual de sílica é alto, o que poderia ser explicado pela presença dos xenólitos félsicos presentes na amostra. As amostras das três ilhas, plotadas no campo do basanito/tefrito, foram classificadas como basanitos, por apresentar índice percentual de olivina acima dos 10\%, baseado em Le Maitre et al. (1989).

Observando a distribuição das rochas no diagrama de álcalis em função de $\mathrm{SiO}_{2}$ (Figura 9), nota-se que as variações químicas indicam a existência de duas tendências de séries magmáticas distintas.

Ambas as séries se projetam no campo das rochas magmáticas alcalinas, sendo uma evoluída para fonolito, enquanto a outra para traquito. Rochas pertencentes às três ilhas aparecem em ambas as séries. A primeira, com teores mais altos de álcalis, demarcada pela cor azul, situada do lado esquerdo da figura, é composta por um picro-basalto (Ano-Bom), quatro basanitos (Ano-Bom, São Tomé e Príncipe), bem como um fonotefrito e dois fonolitos (Príncipe), demarcando um maior grau de insaturação em silica. A segunda, com menor teor de álcalis, marcada pela cor vermelha, situada do lado direito, é constituída por dois picro-basaltos e dois basaltos (Ano Bom e São Tomé), um traquiandesito (Príncipe) e dois traquitos (AnoBom e São Tomé), que se apresentam saturados em sílica. Salientando que cada uma das ilhas apresenta uma amostra duplicata.

O estudo dos elementos principais efetuados nas rochas apresenta alguma variabilidade quanto ao grau de saturação em sílica, onde o teor de $\mathrm{SiO}_{2}$ é utilizado como parâmetro de diferenciação e análise comparativa. As rochas estudadas abrangem um intervalo entre $42,32 \%$ de sílica (em massa) no picro-basalto e 67,84\% (em massa) no traquito, resultando em termos desde ultrabásicos até ácidos (Figura 9). Entretanto, a maioria das amostras se concentra no intervalo entre rochas básicas e ultrabásicas. Os álcalis circunscrevem uma variação bastante alargada, com os seus teores a flutuar entre $2,6 \%$ (em massa) no picro-basalto e $16,8 \%$ (em massa) no fonolito. 


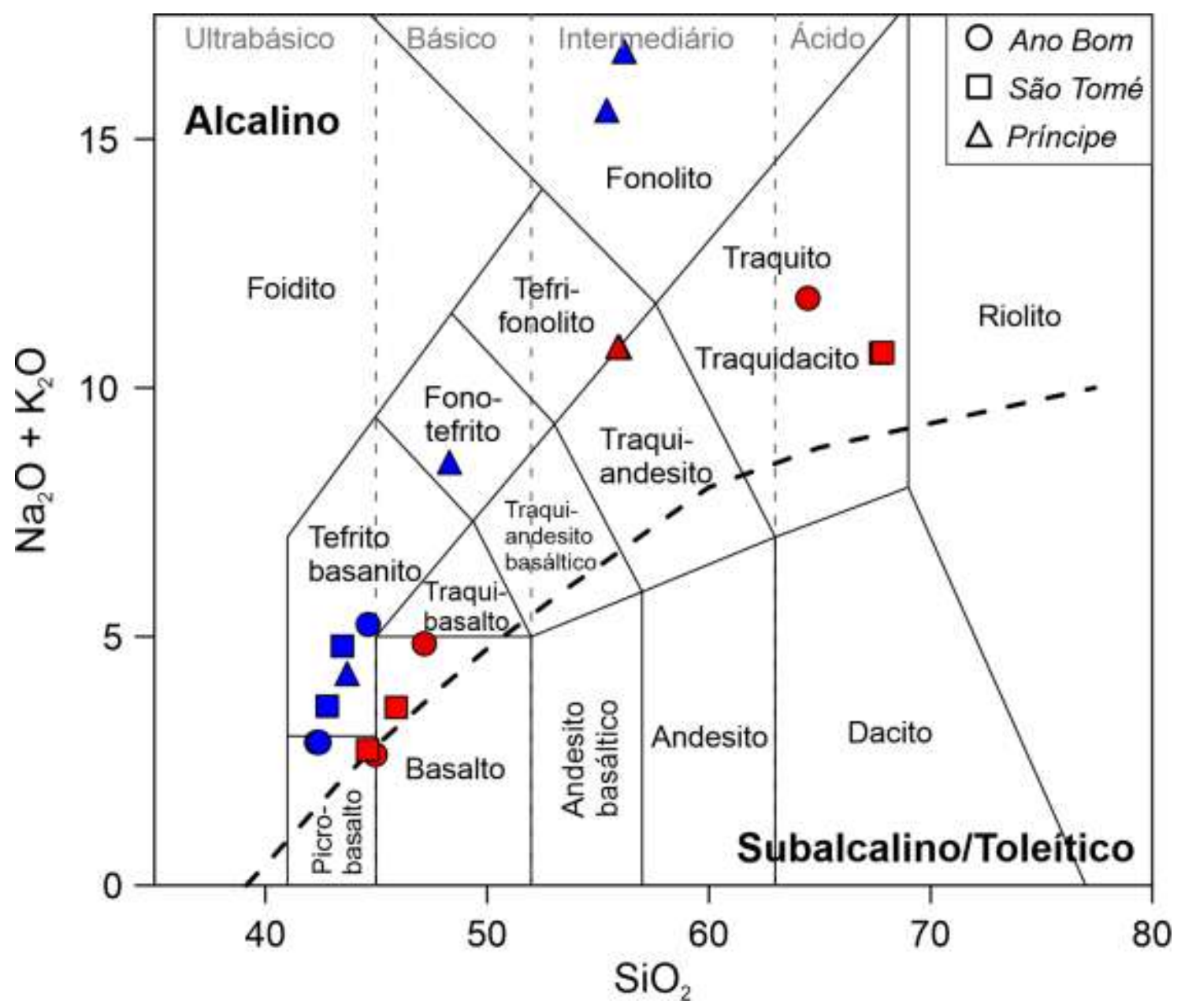

Figura 9: Diagrama de classificação de rochas vulcânicas de Le Bas et al. (1986).

Legenda - Cores: Azul= série rica em álcalis; Vermelho= série rica em sílica.

Círculo= Ilha de Ano-Bom; Quadrado= Ilha de São Tomé; Triangulo= llha do Príncipe.

Pelos cálculos da norma CIPW, os traquitos (AB3-PF e P12A-IC) das llhas de AnoBom e São Tomé ostentam elevado grau de saturação em sílica, tendo quartzo normativo de 6,6 e 12,2\%, respectivamente, e hipersténio normativo $(2,6 \%)$, enquanto que os fonolitos da llha do Príncipe apresentam-se insaturados em sílica, tendo a nefelina normativa de até $31,9 \%$, conforme a tabela $7 \mathrm{~A}$. As mesmas rochas que denotam elevado grau de saturação em sílica são as mais diferenciadas e apresentam coríndon normativo, entre 2,48 e 3,9\%, indicando o carater peraluminoso dessas rochas. O picro-basalto (AB5-MB) e o basanito (P2-AD) denotam um carater não alcalino, com hipersténio normativo entre 1,56 e 2,46\%, e encontram-se num limite transicional alcalino-subalcalino toleítico. Estes tipos de rochas subalcalinas com tendências toleíticas têm pouca ocorrência no continente e com idades antigas, não tendo referências delas em ilhas oceânicas, o que requer maior relevância de estudos destas rochas nas ilhas do Golfo da Guiné. A presença 
de ortopiroxênio com formato anguloso e corroído na borda, nas rochas primitivas, 0 picro-basalto (AB9-PC) em Ano-Bom e o basalto (P1-IC) em São Tomé, representa baixa alcalinidade na composição modal, demonstrando um desequilibrio do mineral com o magma. Provavelmente se trata de um xenocristal de material mantélico.

\subsubsection{Elementos Maiores e Menores}

Observando a distribuição dos dados obtidos nos diagramas que levam em consideração o $\mathrm{MgO}$ como índice de diferenciação dos elementos principais (Diagramas Harker, Figura 10), é perceptível vislumbrar que $\mathrm{SiO}_{2}, \mathrm{Al}_{2} \mathrm{O}_{3}, \mathrm{~K}_{2} \mathrm{O}, \mathrm{Na}_{2} \mathrm{O}$ manifestam de modo geral um progressivo empobrecimento com o aumento do grau de evolução do teor de óxido de magnésio para as amostras analisadas, gerando correlações negativas.

Outrossim, é observado que $\mathrm{TiO}_{2}, \mathrm{Fe}_{2} \mathrm{O}_{3}, \mathrm{MnO}, \mathrm{CaO}$ e $\mathrm{P}_{2} \mathrm{O}_{5}$ exibem enriquecimento com o aumento do teor de óxido de magnésio, gerando correlação positiva, sendo estes os principais elementos constituintes de minerais máficos.

Dentre os óxidos, o $\mathrm{MnO}$ é aquele que apresenta teores percentuais constantemente baixos em todo o conjunto de amostragem, com uma flutuação entre 0,05 e 0,26\% (em massa). No entanto, o comportamento do $\mathrm{TiO}_{2}$ apresenta uma tendência inicialmente positiva com o aumento concomitante do teor de $\mathrm{MgO}$, mas posteriormente surge uma ligeira curva com tendência descendente dos valores do óxido de titânio, indicando um ponto de saturação de $\mathrm{MgO}$ em aproximadamente $6,12 \%$ (em massa).

Nesses diagramas de óxidos em função de MgO (Figura 12), é perceptível que as rochas mais evoluídas apresentam valores bastante baixos de $\mathrm{MgO}$, enquanto que as rochas mais primitivas são as que apresentam valores mais elevados. O MgO apresenta uma variância diferenciada de teores percentuais, em que o valor mais baixo é $0,07 \%$ (em massa) no traquito e o mais elevado é $16,53 \%$ (em massa) no picro-basalto. Salientando que os valores dos elementos principais são dados em percentagem de peso.

Verificado ao pormenor, nota-se uma tendência de mistura dos diagramas de variação elemental das duas famílias de rochas alcalinas que evoluíram de modo distinto, representadas com maior evidência apenas no diagrama TAS. 

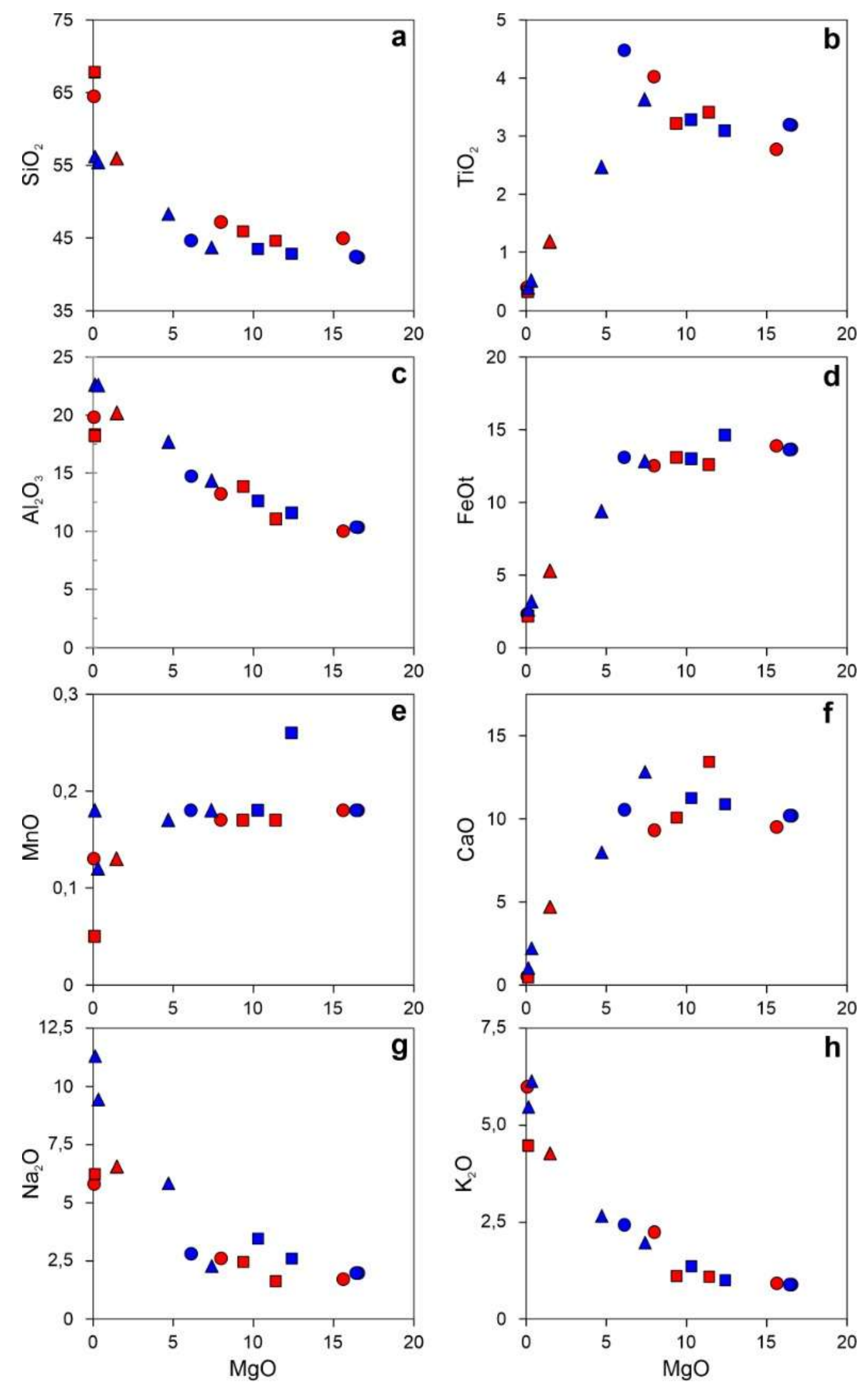

Figura 10: Diagramas de Harker de variação de óxidos de elementos maiores e menores, usando MgO como índice de diferenciação.

Legenda - Cor Azul= Série rica em álcalis; Vermelha= Série rica em sílica. Círculo: Ano-Bom; Quadrado= São Tomé; Triangulo $=$ Ilha do Príncipe. 
De um modo geral, o comportamento dos elementos maiores e menores nos diagramas de variação dos óxidos é muito similar para as rochas das três ilhas, sugerindo que os magmas parentais sejam possivelmente provenientes da mesma fonte mantélica.

\subsubsection{Elementos Traço}

Suportados pelos dados analíticos obtidos pela FRX, foram confecionados gráficos dos elementos traço, considerando o óxido de magnésio como índice de diferenciação, de modo a poder entender as relações comportamentais dos elementos incompatíveis.

Dentre os diagramas de Harker expostos (Figura 11), pode-se verificar que $\mathrm{Ba}, \mathrm{Ce}, \mathrm{Ga}, \mathrm{Nb}, \mathrm{Rb}$ e $\mathrm{Zr}$ apresentam correlações negativas com o aumento do teor de $\mathrm{MgO}$, enquanto $\mathrm{Co}, \mathrm{Cr}, \mathrm{Ni}, \mathrm{V}$ e $\mathrm{Y}$ indicam comportamentos opostos, ou seja, apresentam correlações positivas, crescendo com o aumento do teor de $\mathrm{MgO}$. Salienta-se que os teores dos elementos traços são dados em ppm.

Entre os elementos LILE (Large Ion Lithophile Elements), Ba e Sr são os que mais apresentam semelhanças comportamentais. Estes elementos configuram-se como os que têm elevados teores, entretanto, existe uma ligeira diferença de concentração maior de $\mathrm{Ba}$, uma vez que seu teor aumenta com o fracionamento, de 312 ppm no basalto (São Tomé) para 1262 ppm no traquito (São Tomé). Enquanto isso, o Sr exibe uma maior concentração no fonotefrito (Príncipe), com teor de 1229 ppm e mais baixa no traquito (São Tomé), com 139 ppm. Ambos os elementos apresentam correlações negativas, com o decréscimo de seus teores em relação à ascendência dos índices percentuais de $\mathrm{MgO}$, a partir do fonotefrito. Os elevado valor desses elementos no fonotefrito pode provavelmente estar ligado à presença de macrocristais de anfibólio (kaersutita), semelhante ao que ocorre no arquipelago Fernando de Noronha (Lopes, 2002).

As rochas félsicas, como traquiandesitos, traquitos e fonólitos, são as que apresentam maior abundância de $\mathrm{Rb}$, dentre os conjuntos analisados, sendo que este elemento apresenta uma variação entre 15 e 196 ppm.

Dentre os elementos-traços, $\mathrm{Cr}$, Co e $\mathrm{Ni}$ são os que apresentam algumas similaridades, tendo valores ascendentes com o enriquecimento do óxido de $\mathrm{Mg}$. Estes apresentam duas linhas de crescimento paralelas, provavelmente pelo fracionamento de minerais ferromagnesianos, compatível com fracionamento da 
olivina (entre 10-16,53\% de $\mathrm{MgO}$ ), e clinopiroxênio (entre 0,67-10\% de $\mathrm{MgO}$ ). As rochas primitivas, como os picro-basaltos (Ano-Bom) e basanitos (São Tomé) respectivamente, são as que apresentam valores mais elevados de $\mathrm{Cr}$, Co e $\mathrm{Ni}$, e opostamente, encontram-se as rochas mais evoluídas (traquitos e fonolitos), que apresentam ausência total de teores de $\mathrm{Cr}$ e Ni, e baixos teores de Co. Os valores mais altos para Ni nas rochas supracitadas (picro-basaltos) são de 462 e 544 ppm, e concernente ao $\mathrm{Cr}$, sua maior concentração é de $814 \mathrm{ppm}$ (basanito). O Co tende a apresentar uma ligeira semelhança comportamental conforme o diagrama abaixo (Figura 11), e sua maior concentração é de 91 ppm (picro-basalto).

Quanto aos HFSE (High Field Strengh Elements) $\mathrm{Zr}$ e $\mathrm{Nb}$ denotam correlações negativas análogas, com certa similaridade de dispersão nos comportamentos, alcançando valores mais elevados nos fonolitos e diminuindo consideravelmente nos picro-basaltos. O Zr é o que exibe maior abundância, com a variação de teores entre 212 e 1217 ppm, enquanto que o $\mathrm{Nb}$ tem baixas proporções que variam entre 34 e 199 ppm.

Os ETR (Elementos de Terras Raras) leves, La e Ce evidenciam correlações negativas com o aumento do teor de $\mathrm{MgO}$, variando de modo similar, porém com pequenas diferenças em algumas amostras, apresentando seus valores mais altos nas rochas mais evoluídas. Já $\mathrm{V}$ e $\mathrm{Y}$ não denotam correlação positiva perfeita, evidenciando uma certa dispersão, primeiramente com uma ascensão e um posterior declínio, onde o ponto de inflexão descendente desses elementos está centralizado no basanito (AB4-AW) de Ano-Bom, possivelmente pela cristalização dos óxidos (minerais opacos).

Os diagramas dos elementos traço manifestam particular relevância na obtenção de informações concernentes à origem de rochas ígneas, inclusive as características geoquímicas das fontes que possivelmente sofreram fusão, bem como na interpretação do processo de diferenciação magmática.

Da mesma forma que para os elementos maiores e menores, também os elementos traço apresentam, nos diagramas de Harker, um comportamento muito similar para as rochas das três ilhas, acompanhando a hipótese de que possivelmente os magmas parentais sejam provenientes da mesma fonte mantélica. 

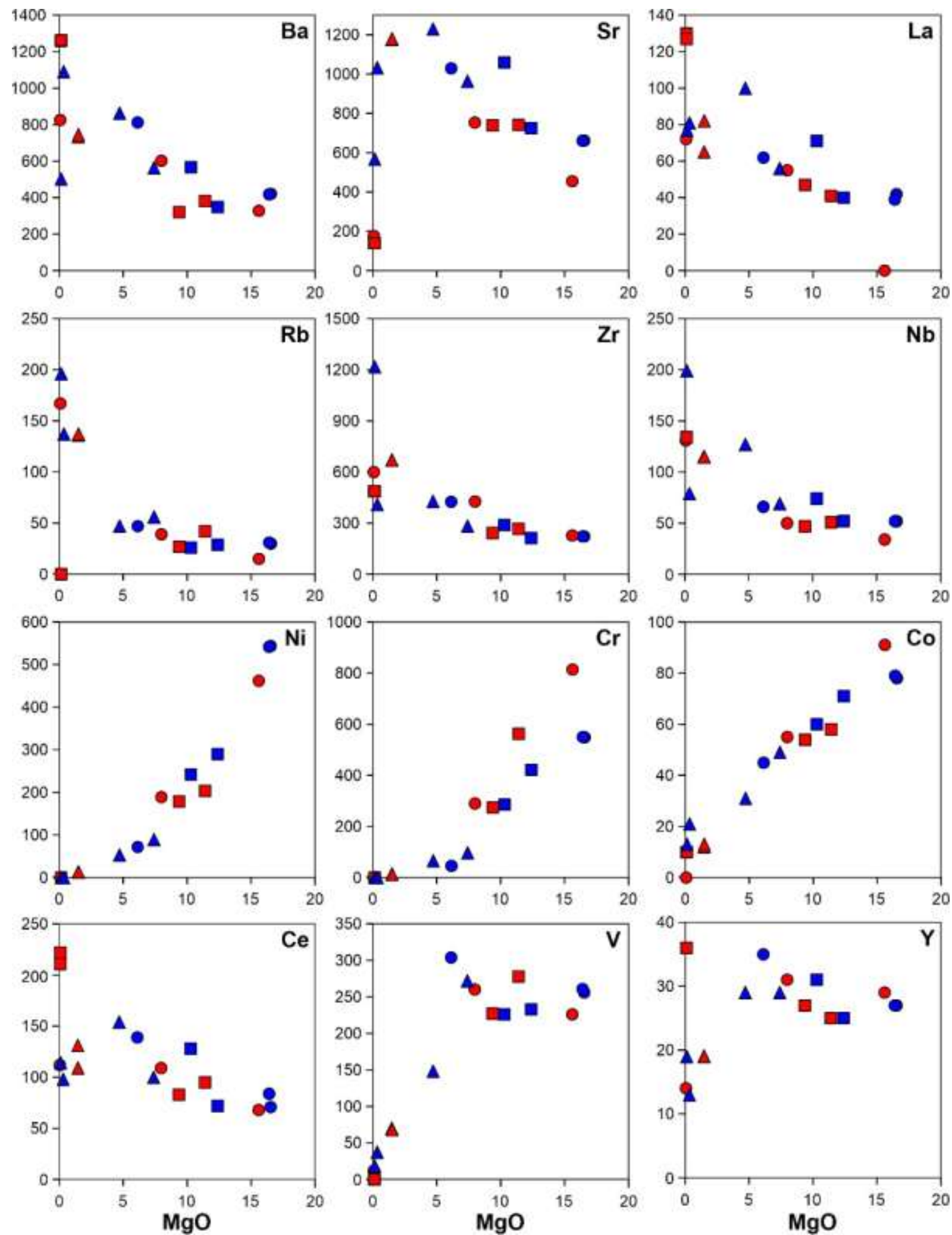

Figura 11: Diagramas de Harker de variação de elementos traço, tendo $\mathrm{MgO}$ como índice de diferenciação.

Legenda - Cor Azul= Série rica em álcalis; Vermelha= Série rica em sílica. Círculo: Ano-Bom; Quadrado= São Tomé; Triangulo= Ilha do Príncipe. 
No diagrama de classificação de rochas TAS, pode-se distinguir dois conjuntos de tendências magmáticas alcalinas, englobando desde termos primitivos até termos mais evoluídos, compreendendo rochas máficas e félsicas. Constata-se que uma das séries alcalinas $\left(42 \%<\mathrm{SiO}_{2}<56 \%\right)$ é composta por picro-basalto, basanitos, fonotefrito e fonolitos, e a outra série $\left(44 \%<\mathrm{SiO}_{2}<68 \%\right)$ é nela reconhecida picro-basaltos, basaltos, traquiandesito e traquitos. Asaah et al. (2015), na sua análise aos conjuntos de rochas dos diversos centros vulcânicos da LVC, faz menção à existência de duas séries magmáticas como constituintes da Linha Vulcânica dos Camarões. As mesmas são encontradas neste estudo para o setor oceânico, o que indica uma consistência com estudos anteriores.

Conforme os aspectos referenciados na petrografia, na composição de minerais constituintes de rochas, bem como as características realçadas nos dados geoquímicos dos diferentes litotipos (magmatismo alcalino bimodal), os resultados nos levam a considerar a cristalização fracionada de magmas parentais alcalinos básicos, como o principal processo atuante na geração de variedades de rochas reconhecidas nessas ilhas vulcânicas. Isto é visível com a indigência quase que constante de $\mathrm{TiO}_{2}, \mathrm{Fe}_{2} \mathrm{O}_{3}$ t, $\mathrm{MgO}$ e $\mathrm{CaO}$, concomitante ao enriquecimento de $\mathrm{SiO}_{2}$, $\mathrm{Al}_{2} \mathrm{O}_{3}, \mathrm{Na}_{2} \mathrm{O}$ e $\mathrm{K}_{2} \mathrm{O}$, de lavas basálticas para félsicas das rochas das ilhas oceânicas do Golfo da Guiné, similar ao que ocorre em Tristan da Cunha e Fernando de Noronha, de acordo com Le Roex et al. (1990) e Lopes (2002), pressupondo que houve atuação de processos de cristalização fracionada, como papel preponderante na formação e evolução de magmas parentais. Alguns aspectos observados nos comportamentos geoquímicos de elementos traço, como $\mathrm{Ni}, \mathrm{Cr}$ e Co, indica possível cristalização de olivina e clinopiroxênio.

A relação de similaridade composicional de ambos os setores da LVC indica rápida ascenção do magma implicando em pouca significância na contaminação por crosta continental nas rochas máficas, embasado na presença de xenólitos do manto em boa parte dos basaltos e basanitos (Fitton and Dunlop, 1985; Marzoli et al., 2000; Aka et al., 2004; Rankenburg et al., 2005; Déruelle et al., 2007; Asaah et al., 2015). No entanto, é provável que tenha havido ocorrência de contaminação crustal nas lavas mais evoluídas, tanto no setor oceânico quanto no continental, em vista das elevadas razões isotópicas de Sr encontradas principalmente nos traquitos das ilhas de Ano-Bom e São Tomé. 


\section{Geoquímica isotópica}

Estudos isotópicos do vulcanismo oceânico auxiliam na caracterização das fontes mantélicas e na evolução de magmas do tipo OIB (Ocean Island Basalts). Diversas pesquisas demonstraram que os isótopos radiogênicos $(\mathrm{Sr}, \mathrm{Nd}$ e $\mathrm{Pb}$ ) sobrevivem ao fracionamento químico e a fusão parcial, tidos como principais processos formadores de rochas nesses casos.

Nas ilhas do Golfo da Guiné, alguns estudos isotópicos foram realizados por Halliday et al. $(1988,1990)$ e Lee et al. (1994), entre outros. No CPGeo-USP, dados isotópicos de $\mathrm{Sr}$ e $\mathrm{Nd}$ foram obtidos para a ilha de São Tomé, para constar da monografia de trabalho de formatura do presente autor (Lopes, 2010), os quais foram comentados de forma preliminar por Lopes et al. (2011).

A estes dados pré-existentes estão sendo adicionados, neste trabalho, uma série de resultados de geoquímica isotópica de $\mathrm{Sr}, \mathrm{Nd}$ e $\mathrm{Pb}$, na maioria das amostras (10) analisadas na geoquímica de rocha total, acima descritas, para as ilhas de Ano-Bom (4), São Tomé (1) e Príncipe (5). Esses resultados serviram de base para a construção de vários diagramas binários, tendo como objetivo a caracterização das fontes mantélicas dos magmas precursores. Os resultados da geoquímica isotópica de ${ }^{87} \mathrm{Sr} /{ }^{86} \mathrm{Sr}$ foram corrigidos para razões iniciais, de acordo com as idades máximas obtidas de cada unidade vulcânica. Tendo em vista que todas as rochas analisadas são jovens, os dados recalculados não diferiram muito dos dados medidos, com a excepção dos traquitos das ilhas de Ano-Bom e São Tomé, que apresentam razões $\mathrm{Rb} / \mathrm{Sr}$ mais elevadas. Por não ter feito as análises de elementos terras raras, não nos foi possível recalcular as razões iniciais de ${ }^{143} \mathrm{Nd} /{ }^{144} \mathrm{Nd}$.

Ocorreu um erro analítico relativo às análises do fonolito (L6A-PP) da ilha do Príncipe, que inviabilizou a exposição de seus resultados de $\mathrm{Nd}$.

Nos diagramas foi localizado o domínio relativo ao atual Atlântico MORB, e foi também evidenciada a posição dos componentes mantélicos DMM, HIMU, EM-I, EM-II e FOZO, bem como de algumas ilhas originadas durante a abertura do Atlântico, adaptado de Lee et al. (1994), Stracke et al. (2005) e Yang et al. (2014).

\subsubsection{Isotopos de $\mathrm{Sr}$ e $\mathrm{Nd}$}

A tabela 8 apresenta os resultados da geoquímica isotópica de $\mathrm{Sr}$ e $\mathrm{Nd}$ das rochas vulcânicas análisadas para esta dissertação. Foram também agregados 
dados conhecidos (Tabela 8a) das três ilhas (Ano-Bom, São Tomé e Príncipe), produzidos por Halliday et al. (1990), Lee et al. (1994) e Lopes (2010) para construção do diagrama das razões iniciais de estrôncio e de neodímio (Figura 12).

As razões de ${ }^{87} \mathrm{Sr} /{ }^{86} \mathrm{Sr}$ medidas para as três ilhas variam entre $0,7030 \mathrm{e}$ 0,7043 , enquanto que as razões de ${ }^{143} \mathrm{Nd} /{ }^{144} \mathrm{Nd}$ medidas variam entre $0,5128 \mathrm{e}$ 0,5130 . Todas as amostras analisadas revelaram $\varepsilon N d$ positivo, correspondendo a material proveniente do manto empobrecido, com valores flutuando entre $+3,78$ (basalto) e $+5,82$ (basanito), sendo os mais altos correspondentes às rochas do Príncipe.

Com relação às razões iniciais de ${ }^{87} \mathrm{Sr} /{ }^{86} \mathrm{Sr}$, verifica-se que elas são mais altas em Ano-Bom e São Tomé em comparação às do Príncipe.

Relativamente à razão ${ }^{143} \mathrm{Nd} /{ }^{144} \mathrm{Nd}$, verifica-se que os valores são bastante aproximados para a generalidade das três ilhas. Da ilha mais antiga (Príncipe) para a mais jovem (Ano-Bom), verifica-se um aumento dos valores de $\mathrm{Sr}(0,70300$ 0,70431). A diferença mais expressiva é refletida nos traquitos de Ano-Bom e São Tomé, onde as razões iniciais de ${ }^{87} \mathrm{Sr} /{ }^{86} \mathrm{Sr}$ para ambos são de 0,70384 e 0,70378 respectivamente.

Tabela 8: Resultados de isotopos de $\mathrm{Sr}$ e $\mathrm{Nd}$ das amostras analisadas nas ilhas.

\begin{tabular}{|c|l|l|l|l|l|l|r|}
\hline Ilha & Amostra & Material & ${ }^{87} \mathbf{S r}{ }^{86} \mathbf{S r}$ & erro (2s) & ${ }^{143} \mathbf{N d} /{ }^{144} \mathbf{N d}$ & erro (2s) & $\varepsilon_{\text {Nd }}$ \\
\hline São Tomé & P12A-IC & Traquito & 0,704309 & 0,000050 & 0,512869 & 0,000009 & 4,51 \\
\hline \multirow{5}{*}{ Príncipe } & L1-ST & Fonotefrito & 0,703026 & 0,000024 & 0,512936 & 0,000008 & 5,81 \\
\cline { 2 - 8 } & L5-TV & Basanito & 0,703003 & 0,000021 & 0,512936 & 0,000005 & 5,82 \\
\cline { 2 - 8 } & L6A-PR & Fonolito & 0,703159 & 0,000018 & ---------- & ---------- & ----- \\
\cline { 2 - 8 } & L10-RF & Fonolito & 0,703064 & 0,000036 & 0,512921 & 0,000003 & 5,52 \\
\cline { 2 - 8 } & L11-PP & Tefrifonolito & 0,703165 & 0,000012 & 0,512924 & 0,000006 & 5,58 \\
\hline \multirow{5}{*}{ Ano-Bom } & AB3-PF & Traquito & 0,704022 & 0,000035 & 0,512867 & 0,000006 & 4,47 \\
\cline { 2 - 8 } & AB4-AW & Basanito & 0,703587 & 0,000028 & 0,512868 & 0,000003 & 4,49 \\
\cline { 2 - 8 } & AB5-MB & Picro-basalto & 0,703596 & 0,000035 & 0,512889 & 0,000004 & 4,89 \\
\cline { 2 - 8 } & AB7-AB & Basalto & 0,703893 & 0,000014 & 0,512832 & 0,000005 & 3,78 \\
\hline
\end{tabular}

Levando-se em consideração as variações isotópicas das três ilhas, expostas no diagrama de relação das razões iniciais de ${ }^{143} \mathrm{Nd} /{ }^{144} \mathrm{Nd} \mathrm{e}{ }^{87} \mathrm{Sr} /{ }^{86} \mathrm{Sr}$ (Figura 12), de forma a clarear a distribuição dos dados, percebe-se pouca variação para os isótopos de $\mathrm{Nd}$ e uma ampla variação de Sr. As rochas da ilha do Príncipe revelam menor variação isotópica e se agrupam, enquanto que as de Ano-Bom e São Tomé tendem a uma maior distribuição. 
As maiores variações de Sr são observadas nas duas ilhas a sul da LVC. Por outro lado, o comportamento isotópico observado nestas ilhas oceânicas é similar aos apresentados nos outros centros vulcânicos do setor continental do alinhamento. É notória uma sobreposição maior entre as rochas de São Tomé e Príncipe, estando Ano-Bom nas suas proximidades.

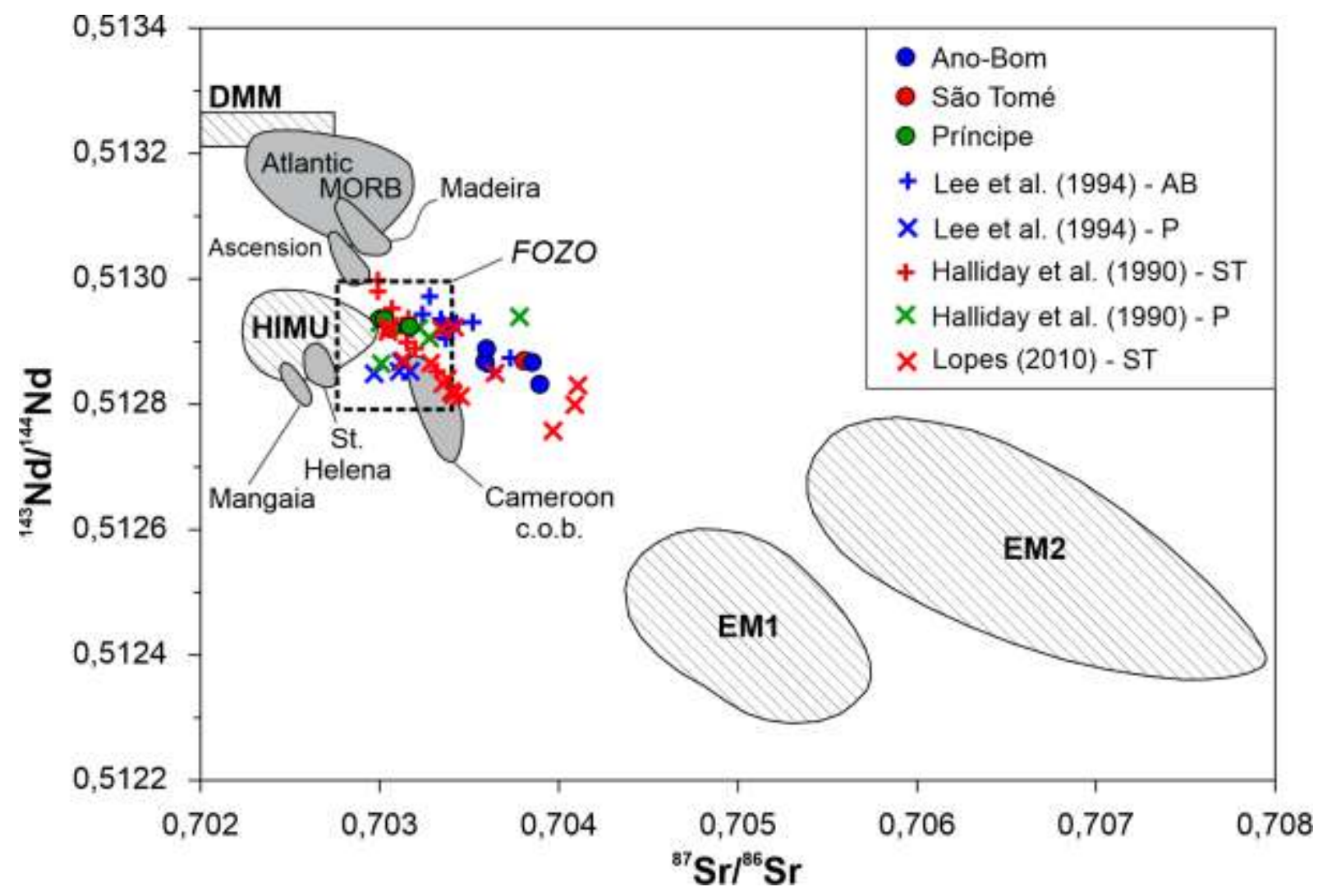

Figura 12: Diagrama de representação de razões isotópicas de $\mathrm{Sr}$ e Nd. Adaptado Lee et al. (1994); Yang et al. (2014) e Asaah et al. (2020). HIMU= High- $\mu$ Mantle, EM I= Enriched Mantle type I, EM II= Enriched Mantle type II e DMM= Depleted MORB Mantle, FOZO= Focal Zone. AB= Ano-Bom, ST= São Tomé, $P=$ Príncipe.

De um modo geral, os resultados evidenciados no diagrama revelam que as rochas das ilhas do Golfo da Guiné, em estudo, são similares a valores encontrados em outras rochas da LVC (Halliday et al., 1990; Lopes et al., 2011; Asaah et al., 2015). Elas são contíguas ao componente mantélico HIMU e DMM, com uma ligeira tendência de afinidade com as rochas da ilha de Santa Helena e ao limite fronteiriço oceano/continente (Cameroon c.o.b). Percebe-se também uma ligeira aproximação das razões isotópicas de Sr e Nd das rochas da ilha de São Tomé com as da ilha de Ascension. 
Por outro lado, grande parte delas se ajustam dentro do domínio FOZO, e também apresentam uma clara tendência de deslocamento em direção aos domínios EM-I e EM-II. Em vista disso, é possível especular que esse magmatismo possa ter sido originado da ressurgência profunda do manto, acima da descontinuidade $410 \mathrm{~km}$, de fonte astenosférica com assinatura FOZO, com certa mistura de componentes HIMU e DMM, e com alguma contribuição do componente EM-I, produzindo eventualmente lavas intermediárias incomuns.

\subsubsection{Isotopos de $\mathrm{Pb}$}

$\mathrm{Na}$ tabela 9 estão expostos os resultados das análises de geoquímica isotópica de $\mathrm{Pb}$, de rochas das três ilhas do setor oceânico da LVC, extraídas para este trabalho. A esses dados, também foram agregados dados isotópicos conhecidos (Tabela 9a) de Halliday et al. (1990) para as ilhas de São Tomé e Príncipe, e de Lee et al. (1994) para Ano-Bom e Príncipe, para a confecção dos respetivos diagramas (Figuras 13 e 14).

As ilhas em estudo apresentam variações das razões iniciais de $\mathrm{Pb}$ que flutuam entre 19,036 e 20,409 para ${ }^{206} \mathrm{~Pb} /{ }^{204} \mathrm{~Pb}$, entre 15,603 e 15,693 para ${ }^{207} \mathrm{~Pb} /{ }^{204} \mathrm{~Pb}$, e por fim, entre 39,111 e 39,987 para ${ }^{208} \mathrm{~Pb} /{ }^{204} \mathrm{~Pb}$.

Tabela 9: Resultados de análises de $\mathrm{Pb}$ das amostras analisadas.

\begin{tabular}{|c|l|l|l|c|l|c|c|c|}
\hline \multicolumn{1}{|c|}{ Ilha } & Amostra & Material & ${ }^{206} \mathbf{P b} /{ }^{\mathbf{2 0 4}} \mathbf{P b}$ & $\mathbf{2 S D}$ & ${ }^{\mathbf{2 0 7}} \mathbf{P b} /{ }^{\mathbf{2 0 4}} \mathbf{P b}$ & $\mathbf{2 S D}$ & ${ }^{208} \mathbf{P b} /{ }^{\mathbf{2 0 4}} \mathbf{P b}$ & $\mathbf{2 S D}$ \\
\hline S. Tomé & P12A-IC & Traquito & 19,440 & 0,005 & 15,638 & 0,004 & 39,553 & 0,011 \\
\hline \multirow{5}{*}{ Príncipe } & L1-ST & Fonotefrito & 20,168 & 0,005 & 15,674 & 0,004 & 39,781 & 0,010 \\
\cline { 2 - 9 } & L5-TV & Basanito & 20,035 & 0,005 & 15,670 & 0,004 & 39,669 & 0,012 \\
\cline { 2 - 9 } & L6A-PR & Fonolito & 20,409 & 0,006 & 15,711 & 0,005 & 39,987 & 0,013 \\
\cline { 2 - 8 } & L10-RF & Fonolito & 20,305 & 0,005 & 15,693 & 0,004 & 39,921 & 0,009 \\
\cline { 2 - 8 } & L11-PP & Tefrifonolito & 20,245 & 0,005 & 15,687 & 0,004 & 39,890 & 0,010 \\
\hline \multirow{4}{*}{$\begin{array}{l}\text { Ano- } \\
\text { Bom }\end{array}$} & AB3-PF & Traquito & 19,036 & 0,008 & 15,610 & 0,007 & 39,265 & 0,019 \\
\cline { 2 - 9 } & AB4-AW & Basanito & 19,062 & 0,007 & 15,603 & 0,006 & 39,111 & 0,019 \\
\cline { 2 - 8 } & AB5-MB & Picro-basalto & 19,261 & 0,022 & 15,605 & 0,018 & 39,256 & 0,045 \\
\cline { 2 - 8 } & AB7-AB & Basalto & 19,341 & 0,004 & 15,650 & 0,004 & 39,500 & 0,009 \\
\hline
\end{tabular}



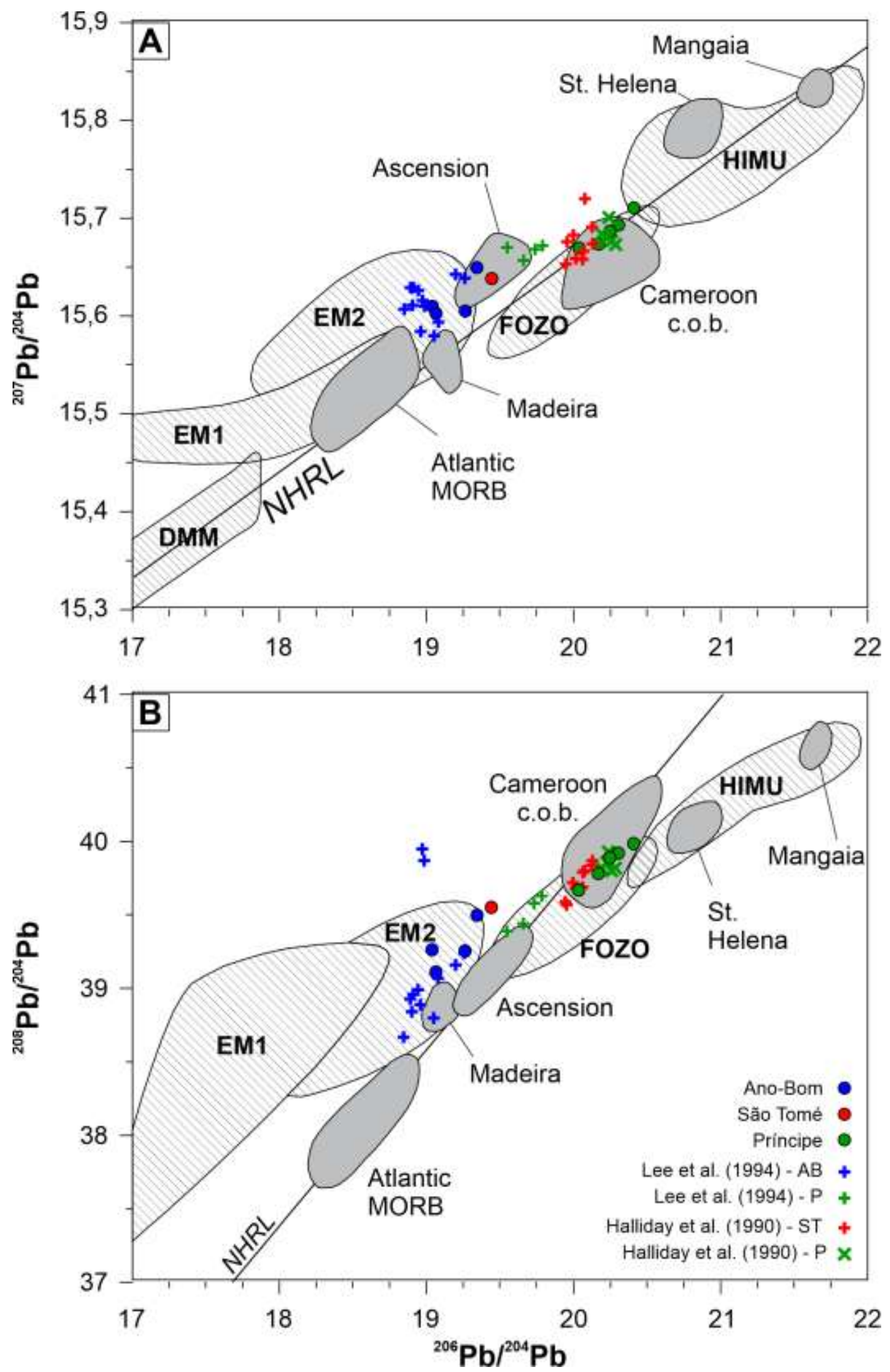

Figura 13: Diagrama de variação isotópica de $\mathrm{Pb}$ das lavas das llhas de Ano-Bom, São Tomé e Príncipe, modificado de Lee et al. (1994); Stracke et al. (2005); e Yang et al. (2014). ST=São Tomé, $\mathrm{P}=$ Príncipe; $\mathrm{Ab}=$ Ano-Bom. $\mathrm{A}=$ Diagrama de variação isotópica de ${ }^{206} \mathrm{~Pb} /{ }^{204} \mathrm{~Pb}$ versus ${ }^{207} \mathrm{~Pb} /{ }^{204} \mathrm{~Pb} ; \mathrm{B}=$ Diagrama de variação isotópica de ${ }^{206} \mathrm{~Pb} /{ }^{204} \mathrm{~Pb}$ versus ${ }^{208} \mathrm{~Pb} /{ }^{204} \mathrm{~Pb}$. 
$\mathrm{Na}$ alternância das razões iniciais de ${ }^{206} \mathrm{~Pb} /{ }^{204} \mathrm{~Pb}$, verifica-se que os valores mais baixos estão centrados na ilha de Ano-Bom, variando entre 18,846 e 19,341, enquanto que os valores mais elevados são encontrados na ilha do Príncipe, variando entre 19,547 e 20,409. São Tomé denota uma variância intermediária, com valores entre 19,440 e 20,128 .

Constata-se que a llha do Príncipe não evidencia ampla variação isotópica, apresentando $\mathrm{Pb}$ mais radiogênico, quando comparada com o que ocorre nas outras duas ilhas. Ano-Bom é a que apresenta $\mathrm{Pb}$ menos radiogênico, dentre as ilhas oceânicas da LVC, o que parece indicar uma diminuição nas proporções de $\mathrm{Pb}$ da ilha mais antiga para a mais jovem.

Percebe-se no diagrama de variação de ${ }^{206} \mathrm{~Pb} /{ }^{204} \mathrm{~Pb}$ versus ${ }^{207} \mathrm{~Pb} /{ }^{204} \mathrm{~Pb}$ (Figura 13A) que os traquitos do llhéu das Cabras e Pico del Fuego (São Tomé e Ano-Bom) se diferenciam dos basaltos das mesmas ilhas, e se colocam próximos um do outro. O fonolito da llha do Príncipe e o basanito de Ano-Bom são os extremos, máximo e mínimo, das proporções de ${ }^{206} \mathrm{~Pb} /{ }^{204} \mathrm{~Pb}$.

Observa-se nos diagramas de ${ }^{206} \mathrm{~Pb} /{ }^{204} \mathrm{~Pb}$ versus ${ }^{207} \mathrm{~Pb} /{ }^{204} \mathrm{~Pb}$ e ${ }^{206} \mathrm{~Pb} /{ }^{204} \mathrm{~Pb}$ versus ${ }^{208} \mathrm{~Pb} /{ }^{204} \mathrm{~Pb}$ (Figuras $13 \mathrm{~A}$ e 13B), que as rochas das três ilhas se agrupam paralelamente à Linha de Referência do Hemisfério Norte (NHRL - Northern Hemisphere Reference Line) definida por Hart (1984). As variações isotópicas de $\mathrm{Pb}$ das ilhas de São Tomé e Príncipe se sobrepõem às do limite fronteiriço oceano/continente, enquanto que a ilha de Ano-Bom é contígua a ilha da Madeira. É visível uma sobreposição de um pequeno grupo de rochas à ilha de Ascension.

A llha do Príncipe apresenta duas assinaturas isotópicas de $\mathrm{Pb}$. Uma delas apresenta razões de ${ }^{206} \mathrm{~Pb} /{ }^{204} \mathrm{~Pb}$ entre 20,035 e 20,409 , obtidos neste trabalho, que se sobrepõem aos dados obtidos por Halliday et al. (1990) nas rochas (fonolito, tefrifonolito, traquifonolito, tristanito e basanito) que representam o vulcanismo mais recente da ilha, de idades inferiores a $8 \mathrm{Ma}$. A outra assinatura de $\mathrm{Pb}$ apresenta razões de ${ }^{206} \mathrm{~Pb} /{ }^{204} \mathrm{~Pb}$ entre 19,547 e 19,786 , distinta das demais acima referenciadas, obtida em hawaítos, representantes do vulcanismo mais antigo da ilha, com idades superiores a $19 \mathrm{Ma}$.

Observando o diagrama de variação isotópica de ${ }^{206} \mathrm{~Pb} /{ }^{204} \mathrm{~Pb}$ versus ${ }^{87} \mathrm{Sr} /{ }^{86} \mathrm{Sr}$ (Figura 14A) e ${ }^{143} \mathrm{Nd} /{ }^{144} \mathrm{Nd}$ (Figura 14B), constata-se que nas rochas da ilha de Ano-Bom existe uma tendência de aproximação ao MORB Atlântico. 
Nos diagramas das variações isotópicas de chumbo, as ilhas do Golfo da Guiné apresentam uma extensão nos valores de ${ }^{206} \mathrm{~Pb} /{ }^{204} \mathrm{~Pb}$ com aproximações nas extremidades entre a ilha da Madeira e o limite de fronteira oceano/continente. As rochas das ilhas de São Tomé e Príncipe se sobrepõem às do limite fronteiriço oceano/continente da LVC, com ligeiras afinidades HIMU para as rochas que representam o vulcanismo recente, enquanto que os hawaítos (vulcanismo antigo) denotam ausência de afinidades HIMU. Ambas as ilhas (São Tomé e Príncipe) são caracterizadas pelo componente FOZO, enquanto que a ilha de Ano-Bom apresenta características distintas deste camponente e se sobrepõe ao EM-II.

Embora exista a possibilidade dessas ilhas serem pertencentes a uma mesma fonte mantélica, dadas as evidências observadas na geoquímica de rocha total, suas rochas não se sobrepõem ao mesmo campo, apresentando assinaturas isotópicas semelhantes em São Tomé e Príncipe, mas com a ilha de Ano-Bom claramente distinta, sugerindo duas fontes distintas para as rochas basálticas alcalinas dessas ilhas. Por outro lado, as rochas das três ilhas sofreram processos de evolução magmática praticamente idênticos.

Analisando de modo criterioso, podemos constatar algumas discrepâncias no caso do $\mathrm{Nd}$ radiogênico. As rochas da ilha do Príncipe, que apresentam valores de $\mathrm{Nd}$ mais elevados, são coincidentes com valores elevados de $\mathrm{Pb}$ e baixos valores de $\mathrm{Sr}$, enquanto que nas rochas de Ano-Bom os valores de $\mathrm{Nd}$ são mais baixos, assim como os baixos valores de $\mathrm{Pb}$, enquanto que o $\mathrm{Sr}$ ostenta valores mais altos, conforme constatado por Lee et al. (1994). 

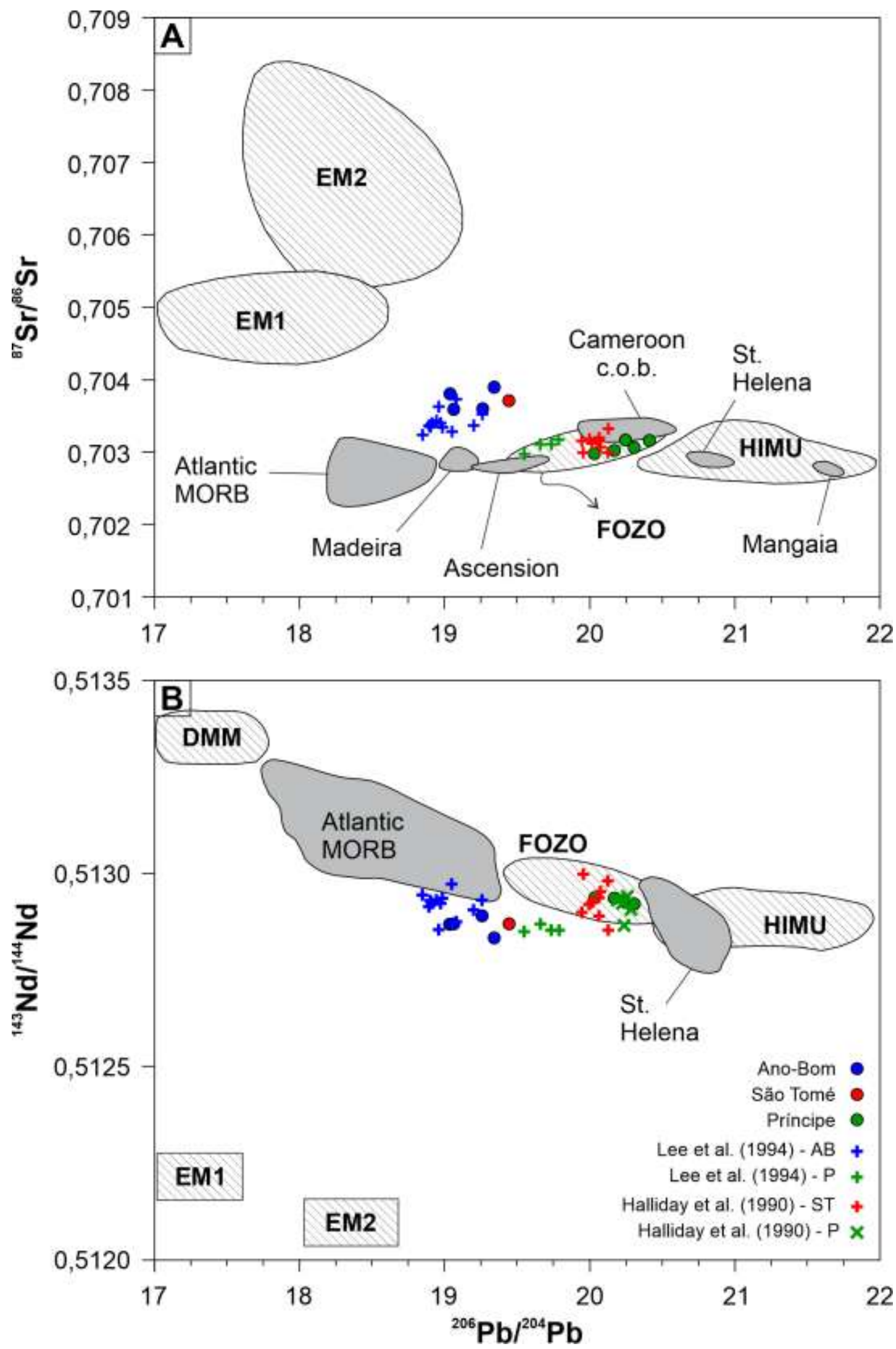

Figura 14: Diagrama de variação isotópica de $\mathrm{Pb}$ das lavas das llhas de Ano-Bom, São Tomé e Príncipe, modificado de Lee et al. (1994); Stracke et al. (2005); e Yang et al. (2014). ST=São Tomé, $\mathrm{P}=$ Príncipe; $\mathrm{Ab}=\mathrm{Ano}-\mathrm{Bom} . \mathrm{A}=$ Diagrama de variação isotópica de ${ }^{206} \mathrm{~Pb} /{ }^{204} \mathrm{~Pb}$ versus ${ }^{87} \mathrm{Sr} /{ }^{86} \mathrm{Sr} ; \mathrm{B}=$ Diagrama de variação isotópica de ${ }^{206} \mathrm{~Pb} /{ }^{204} \mathrm{~Pb}$ versus ${ }^{143} \mathrm{Nd} /{ }^{144} \mathrm{Nd}$. 
A Linha Vulcânica dos Camarões apresenta particularidades interessantes no que diz respeito à ocorrência de vulcanismo alcalino entre os setores continental e oceânico. Esta particularidade é excelente para a comparação do caracter alcalino bimodal de intraplaca oceânico-continental.

As características isotópicas registradas pelos centros vulcânicos da LVC, no limite fronteiriço oceânico-continental, são próximas do componente mantélico HIMU (Zindler and Hart, 1986; Barfod et al., 1999), o mesmo da ilha de Santa Helena. No entanto, conforme vai se distanciando deste limite fronteriço, a assinatura HIMU é perdida, característica essa verificada na ilha de Ano-Bom.

As razões iniciais de ${ }^{87} \mathrm{Sr} /{ }^{86} \mathrm{Sr}$ das rochas basálticas alcalinas das ilhas de Ano-Bom, São Tomé e Príncipe se enquadram no intervalo estipulado para o alinhamento, uma vez que aquelas das rochas vulcânicas ao longo da extensa LVC variam de 0,70291 à 0,70417 (Halliday et al., 1988, 1990).

As variações na razão inicial de $\mathrm{Sr}$ das amostras representativas das três ilhas do setor oceânico da LVC, abaixo de 0,705, indicam uma fonte de manto empobrecido, com pouco tempo de residência crustal, dados os valores positivos do $\varepsilon N d$.

Observando os detalhes de alternância das razões iniciais de ${ }^{87} \mathrm{Sr} /{ }^{86} \mathrm{Sr}$ e ${ }^{143} \mathrm{Nd} /{ }^{144} \mathrm{Nd}$ das rochas basálticas expostas, verifica-se que as três ilhas apresentam semelhanças com a maioria dos centros vulcânicos do setor continental. Porém, as ilhas do setor oceânico são ligeiramente mais radiogênicas em relação ao Monte Camarões (Yokoyama et al., 2007), Monte Monengouba (Pouclet et al., 2014), e próximas ao manto MORB Atlântico e ao HIMU, com características químicas empobrecidas relativamente aos basaltos das ilhas oceânicas (OIB).

A variação das razões isotópicas de chumbo para as três ilhas mostra que há um decréscimo da ilha mais antiga para a ilha mais jovem. Príncipe apresenta $\mathrm{Pb}$ mais radiogénico, com pouca variação isotópica de ${ }^{206} \mathrm{~Pb} /{ }^{204} \mathrm{~Pb}$, em relação as suas congêneres à sul do alinhamento. Ano-Bom é aquela que apresenta chumbo menos radiogénico, o que é consistente com o que é exposto sobre a LVC, por Lee et al. (1994).

$\mathrm{Na}$ extensa LVC, uma característica isotópica de $\mathrm{Pb}$ se sobressai, com razões de ${ }^{206} \mathrm{~Pb} /{ }^{204} \mathrm{~Pb}$ relativamente mais altas nos vulcões do limite de fronteira oceano/continente (Monte Camarões, Etinde, Bioko), comparativamente às demais extensões do alinhamento (Halliday et al., 1988). Esses autores referenciam no seu 
estudo que uma amostra da ilha de Ano-Bom exibe $\mathrm{Pb}$ relativamente não radiogênico, comparativamente aos basaltos jovens do setor oceânico, o que havia sido evidenciado também nas outras extremidades da LVC, Adamawa e Biu. Em suas interpretações, as lavas da zona de fronteira oceano/continente herdariam componentes do manto empobrecido com altas razões $\mathrm{Nd} / \mathrm{Pb}$ e $\mathrm{Sr} / \mathrm{Pb}$, em relação as regiões nas suas extremidades. Isto seria visível na representação bimodal das assinaturas isotópicas de chumbo na llha de Príncipe, em que o vulcanismo mais antigo da ilha não apresenta assinatura HIMU, em contraste com o vulcanismo mais recente.

Com base na sistemática isotópica $\mathrm{Sr}-\mathrm{Nd}-\mathrm{Pb}$, as rochas das ilhas em estudo no Golfo da Guiné, excepção de Ano-Bom, se projetam no campo FOZO (Zona Focal), redefinido por Stracke et al. (2005). Este componente mantélico, produzido continuamente pela reciclagem da crosta oceânica, é onipresente nas fontes MORB e OIB, podendo estar presente em todo manto (Yokoyama et al., 2007). FOZO é um componente característico em vários centros vulcânicos ao longo da extensa Linha Vulcânica dos Camarões (Asaah et al., 2015, 2020).

Lopes et al. (2011) referencia um aumento de ${ }^{143} \mathrm{Nd} /{ }^{144} \mathrm{Nd}$ na direção das unidades mais jovens da ilha de São Tomé, como resultado de uma diminuição do componente EM-I e consequente aumento de DMM. Eles propõem que 0 magmatismo da ilha de São Tomé seria derivado de uma assinatura profunda (FOZO), com misturas dos componentes HIMU e DMM, com pouca interferência do manto enriquecido (EM-I), como demonstrado no diagrama de ${ }^{206} \mathrm{~Pb} /{ }^{204} \mathrm{~Pb}$ versus ${ }^{143} \mathrm{Nd} /{ }^{144} \mathrm{Nd}$ (Figura 14B)

\subsection{Geocronologia Ar-Ar}

As mais de cinco dezenas de datações disponíveis até o momento nas rochas das ilhas de Ano-Bom, São Tomé e Príncipe, foram incluídas nas tabelas $2 \mathrm{e}$ 3. Com exceção de quatro datações, determinadas pelo método $\mathrm{Rb}-\mathrm{Sr}$, as demais foram obtidas principalmente pelos métodos $\mathrm{K}$-Ar ou Ar-Ar. Normalmente, nos casos de rochas vulcânicas félsicas, fonolitos ou traquitos, em que suas idades dependem essencialmente de minerais como feldspatos, que contém potássio em quantidade adequada, as datações por estes métodos podem ser consideradas como as épocas de cristalização por resfriamento rápido dos magmas. 
Entretanto, para rochas máficas, basaltos ou basanitos, que correspondem às litologias mais comuns nas ilhas, os resultados podem ser mais difíceis de interpretar. Essas rochas são mais suscetíveis às alterações, seus teores de potássio são mais baixos, alguns minerais como olivinas e piroxênios podem conter argônio em excesso, e normalmente contém vidro devitrificado que pode ter perdido certas quantidades de argônio. O método K-Ar é o mais afetado, e em muitos casos as idades aparentes são mínimas por causa de perdas de argônio. Por outro lado, o método ${ }^{40} \mathrm{Ar} /{ }^{39} \mathrm{Ar}$, permite identificar as amostras expostas à perda e excesso de $\mathrm{Ar}$. Nos casos de aquecimento em etapas sucessivas, pode em muitos casos indicar uma idade próxima da cristalização.

As figuras 15, 16 e 17 ilustram espectros de aquecimento gradual e isócronas normais obtidos após a análise de dez amostras de rocha total (Tabela 10), sendo cinco da ilha de Ano-Bom (AB3-PF, AB4-AW, AB5-MB, AB7-AB, AB9-PC), quatro da ilha do Príncipe (L1-ST, L6A-PP, L10-RF, L11-PP) e uma da ilha de São Tomé (P12A-IC). Inicialmente foram selecionadas um total de onze amostras, porém um erro analítico inviabilizou a obtenção e exposição dos resultados amostrais de uma amostra (L5-TV) da llha do Príncipe. Todas as idades ${ }^{40} \mathrm{Ar} /{ }^{39} \mathrm{Ar}$ apresentadas (plateau, média ponderada, fusão total, isocrônica) foram calculadas considerando incerteza a nível 2б. A idade média ponderada foi calculada para as amostras cujo espectro de aquecimento não forneceu um plateau, e levou em conta a coerência $2 \sigma$ entre etapas não exatamente contíguas. Para a maioria das amostras, essa idade foi considerada a melhor estimativa de idade de formação/solidificação.

Tabela 10: Datações radiométricas pelo método Ar-Ar das llhas de Ano-Bom, São Tomé e Príncipe

\begin{tabular}{|c|c|c|c|c|c|c|c|}
\hline Ilha & Amostra & Material & Idade & Fusão Total & $\begin{array}{l}\text { Isócrona } \\
\text { Normal }\end{array}$ & $\begin{array}{l}\text { Isócrona } \\
\text { Inversa }\end{array}$ & \begin{tabular}{|l|} 
№ de \\
Etapas
\end{tabular} \\
\hline S. Tomé & P12A-IC & Traquito & $14,44 \pm 0,15$ & $14,81 \pm 0,16$ & $14,35 \pm 0,14$ & $14,35 \pm 0,16$ & 13 \\
\hline \multirow{5}{*}{ Príncipe } & L1-ST & Fonotefrito & $7,74 \pm 0,27$ & $7,98 \pm 0,17$ & $7,88 \pm 1,23$ & $7,97 \pm 1,15$ & 13 \\
\hline & L5-TV & Basanito & |--------- & \begin{tabular}{|l|}
--------- \\
\end{tabular} & \begin{tabular}{|l|}
--------- \\
\end{tabular} & ---------- & --------- \\
\hline & L6A-PR & Fonolito & $7,48 \pm 0,43$ & ---------- & --------- & ---------- & 4 \\
\hline & L10-RF & Fonolito & $6,19 \pm 0,10$ & $6,14 \pm 0,07$ & $6,23 \pm 0,13$ & -------- & 2 \\
\hline & L11-PP & Tefrifonolito & $5,95 \pm 0,09$ & $5,98 \pm 0,09$ & $5,95 \pm 0,09$ & $5,91 \pm 0,12$ & 14 \\
\hline \multirow{5}{*}{ Ano-Bom } & AB3-PF & Traquito & $4,58 \pm 0,08$ & $4,37 \pm 0,08$ & $4,70 \pm 0,08$ & $4,41 \pm 0,25$ & 11 \\
\hline & AB4-AW & Basanito & $4,89 \pm 0,13$ & $4,80 \pm 0,13$ & $5,05 \pm 0,05$ & $4,46 \pm 0,53$ & 15 \\
\hline & AB5-MB & Picro-basalto & $5,82 \pm 0,28$ & $5,05 \pm 0,21$ & $5,71 \pm 0,13$ & $5,69 \pm 0,19$ & 2 \\
\hline & $A B 7-A B$ & Basalto & $4,92 \pm 0,12$ & $5,05 \pm 0,15$ & $5,13 \pm 0,05$ & $6,05 \pm 1,58$ & 13 \\
\hline & AB9-PC & Picro-basalto & $4,75 \pm 0,36$ & $5,85 \pm 0,29$ & $3,31 \pm 0,84$ & $3,34 \pm 0,82$ & 5 \\
\hline
\end{tabular}


A idade isocrônica foi calculada com as mesmas etapas selecionadas para a média ponderada ou plateau. A definição de idade plateau considerou três ou mais etapas contíguas, responsáveis por um mínimo de $50 \%$ de ${ }^{39} \mathrm{Ar}$ liberado (idealmente $\geq 70 \%$ ), e sobreposição dentro do intervalo de confiança de $95 \%$.

De forma geral, as idades aparentes de ${ }^{40} \mathrm{Ar} /{ }^{39} \mathrm{Ar}$ para esta dissertação foram relativamente consistentes entre $\mathrm{si}$, e forneceram espectros de aquecimento gradual relativamente constantes, embora a definição de idade plateau, como conceitualmente definido, não tenha sido possível para algumas das amostras analisadas.

Verifica-se que as amostras da liha de Ano-Bom analisadas representam quatro dos cinco litotipos descritos na petrografia, não tendo sido datados apenas os olivina-basaltos aflorantes no extremo norte da ilha. Para o traquito (AB3-PF), representante do Pico del Fuego, que aflora na região centro-norte, o conjunto de onze etapas de aquecimento produziu uma idade média ponderada de 4,58 $\pm 0,08$ Ma (Figura 15a) com $54 \%$ de ${ }^{39} \mathrm{Ar}$ liberado, a qual não pode ser considerada plateau por não atender o requisito de superposição $(2 \sigma)$ entre etapas contíguas. A idade isocrônica de 4,70 \pm 0,08 Ma da amostra, se aproxima à média ponderada, e ambas são mais antigas que a idade de fusão total que considera todas as etapas de aquecimento (4,37 $\pm 0,08 \mathrm{Ma}$; Figura 15b). A distribuição de algumas das etapas de aquecimento com idades aparentes discretamente mais jovens sugere alguma heterogeneidade quanto à retenção de $\mathrm{Ar}$ em sítios cristalográficos dos minerais portadores de $\mathrm{K}$ que constituem a rocha.

O basanito (AB4-AW) e o basalto (AB7-AB) amostrados, respectivamente, de derrames nas regiões sudoeste e nordeste da ilha definiram espectros relativamente consistentes com $78 \%$ e $90 \%$ de ${ }^{39} \mathrm{Ar}$ liberado, a despeito de 1-2 etapas, com idades aparentes mais jovens (perda de $\mathrm{Ar}$ ) registradas no final do aquecimento (Figura 15). Comparativamente, as duas amostras forneceram idades semelhantes em 4,89 \pm $0,13 \mathrm{Ma}$ (Figura 15c) e 4,92 $\pm 0,12 \mathrm{Ma}$ (Figura 15g), as quais não se distinguem (dentro do erro) das idades de fusão total.

As amostras de picro-basaltos AB5-MB e AB9-PC, coletadas respectivamente a sul e norte da ilha, produziram espectros mais perturbados. A comparação entre $O$ comportamento da razão $\mathrm{K} / \mathrm{Ca}$ (não ilustrada) e as idades aparentes no espectro de aquecimento de AB5-MB sugere a influência de fases minerais de alteração em temperaturas mais baixas, passando para domínio gradual das fases de mais alta 
temperatura (piroxênio e plagioclásio, com razão $\mathrm{K} / \mathrm{Ca}$ mais baixas) no final do aquecimento. O comportamento de Ar na parte intermediária do espectro permitiu calcular uma idade média ponderada em 5,82 $\pm 0,28 \mathrm{Ma}$ (Figura 15e) com $36 \%{ }^{39} \mathrm{Ar}$ liberado. As idades isocrônica e de fusão total são, em diferentes proporções, mais jovens. A amostra AB9-PB, por sua vez, é fortemente influenciada por excesso de $\mathrm{Ar}$ atmosférico $\left({ }^{40} \mathrm{Ar} /{ }^{36} \mathrm{Ar}=319\right)$ e $\mathrm{Ar}$ "herdado" (excesso de $\mathrm{Ar}$ ) no fim do aquecimento, provavelmente liberado pelas fases minerais cálcicas presentes. Todas as idades calculadas (média ponderada, fusão total ou isocrônica) falharam em definir um valor coerente entre si.
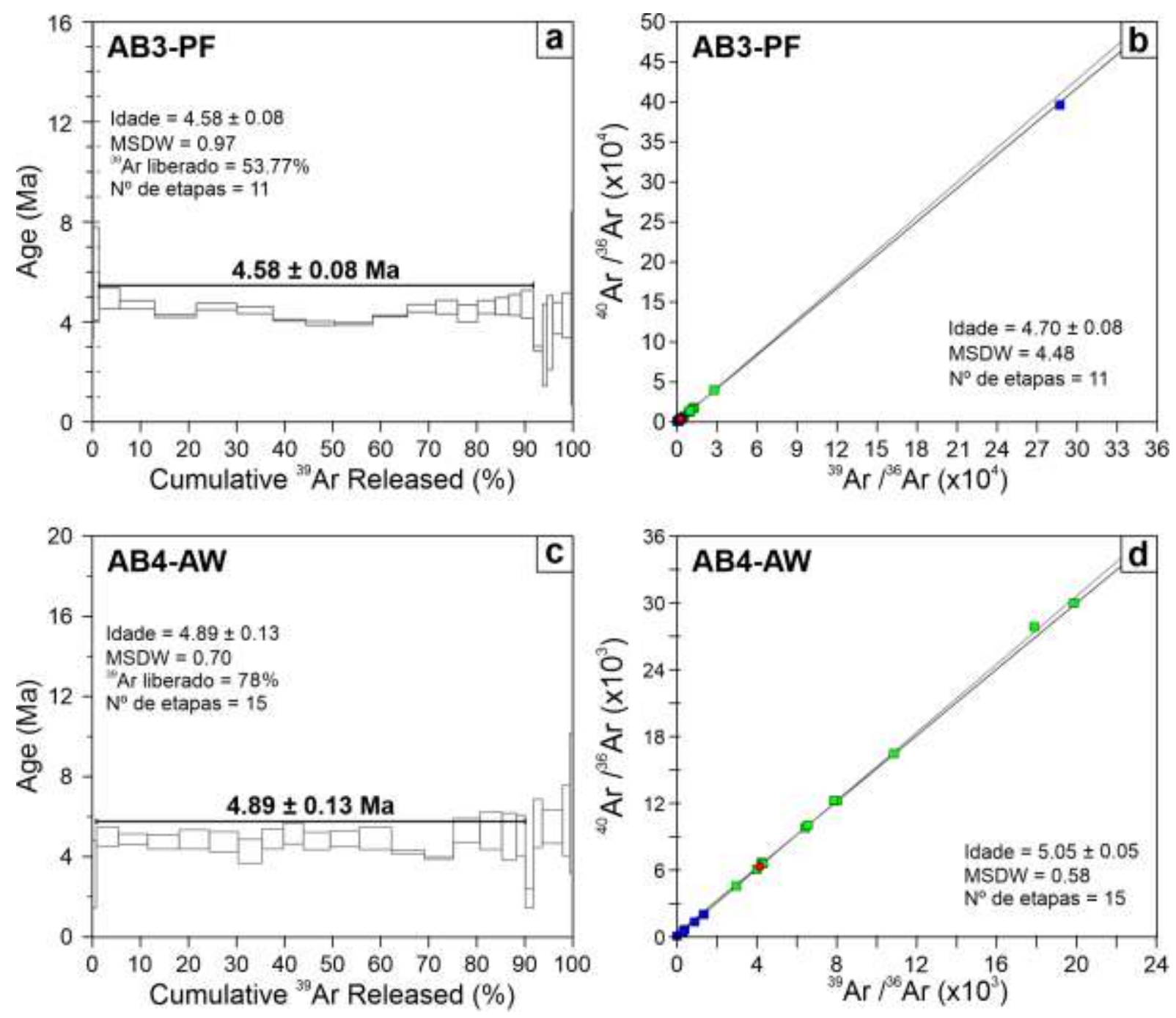

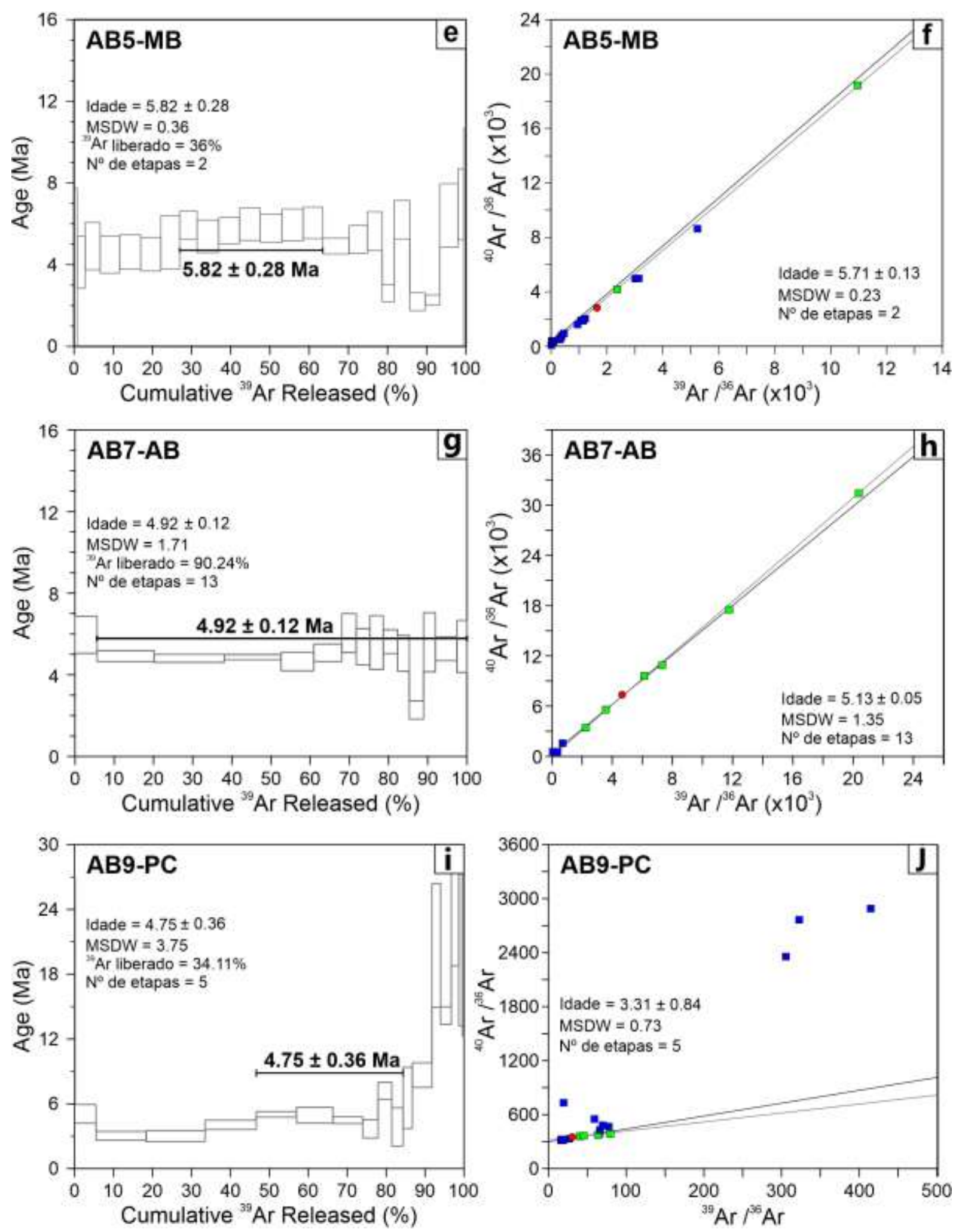

Figura 15: Espectros de aquecimento gradual e isócronas normais, pelo método ${ }^{40} \mathrm{Ar} /{ }^{39} \mathrm{Ar}$.

Para a ilha do Príncipe, foram analisadas com êxito quatro amostras (L1-ST, L6A-PP, L10-RF e L11-PP) classificadas, respectivamente, como fonotefrito, dois fonolitos e traquiandesito. 
O conjunto de sete etapas distribuídas entre as fases de aquecimento de baixa a alta temperatura produziu uma idade média ponderada em 7,74 $\pm 0,27 \mathrm{Ma}$ $\left(62 \%{ }^{39} \mathrm{Ar}\right.$ liberado; Figura 16a) para o fonotefrito L1-ST que aflora na porção central da ilha. Essa idade é idêntica (dentro do erro) à idade isocrônica de 7,12 \pm 0,48 Ma (Figura 16b) e discretamente mais jovem que a idade de fusão parcial (7,98 \pm 0,17 Ma, influenciada pelas idades aparentes mais jovens obtidas à baixa temperatura).

O espectro de aquecimento do fonolito (L6-PP), no centro-leste da ilha, é fortemente perturbado nas etapas de alta temperatura, mas no intervalo entre $5-70 \%$ de liberação de Ar foi possível calcular uma idade média ponderada com quatro etapas ( 44\% $\left.{ }^{39} \mathrm{Ar}\right)$ em 7,48 $\pm 0,43 \mathrm{Ma}$ (Figura 16c). Apesar da incerteza elevada, essa idade se superpõe (no erro) com a idade calculada para a amostra L1-ST, coletada aproximadamente na mesma cota topográfica. Para o fonolito (L10-RF) que aflora a sudeste, o conjunto de quatro etapas de aquecimento produziu uma idade média ponderada de 6,19 $\pm 0,10 \mathrm{Ma}\left(55 \%{ }^{39} \mathrm{Ar}\right.$ liberado; Figura 16e), semelhante às idades de fusão total (6,14 0,07 Ma) e isocrônica (6,23 \pm 0,13 Ma; Figura 19f).

Por fim, o traquiandesito (L11-PP), coletado no extremo sul da ilha, produziu um plateau com quatorze etapas de aquecimento que somaram $94 \%$ de ${ }^{39} \mathrm{Ar}$

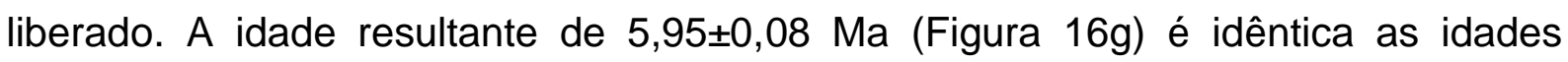
isocrônica (5,95 \pm 0,09 Ma; Figura 19h) e de fusão total (5,98 $\pm 0,09 \mathrm{Ma})$.
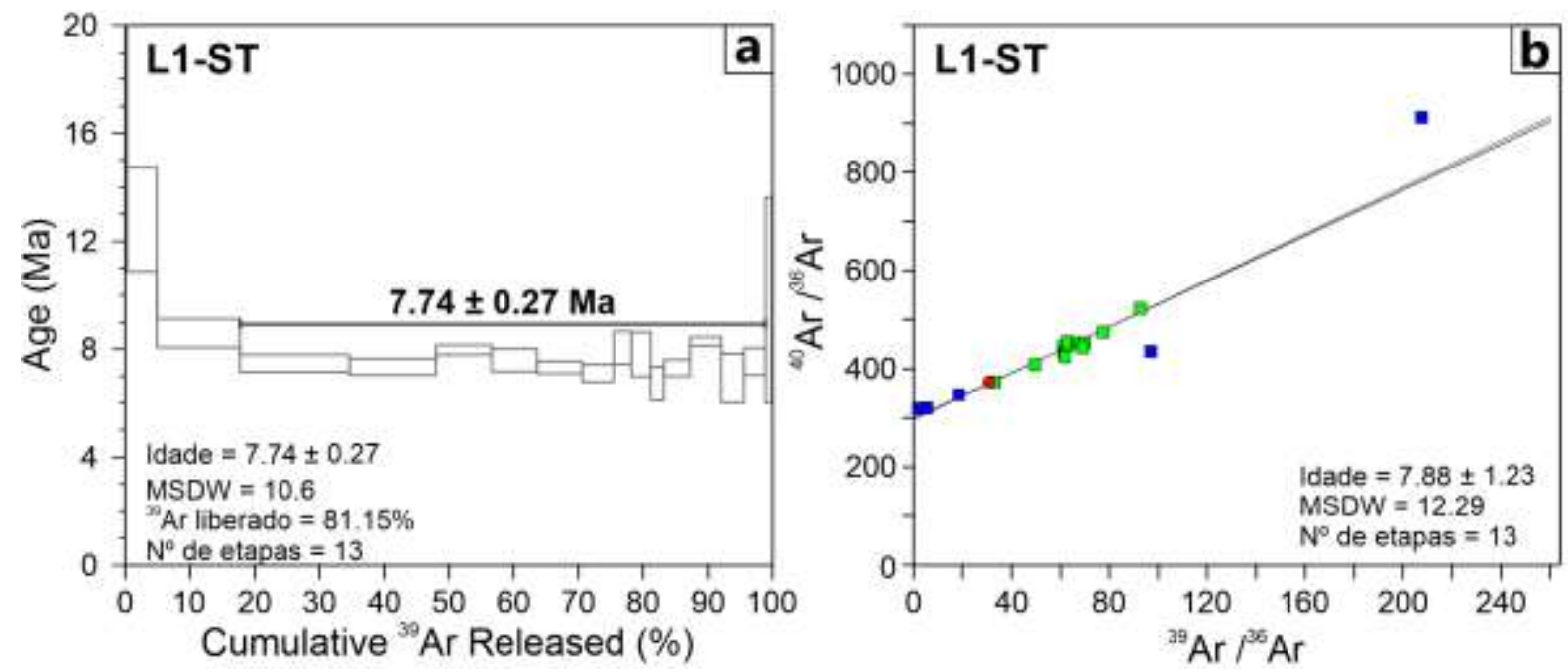

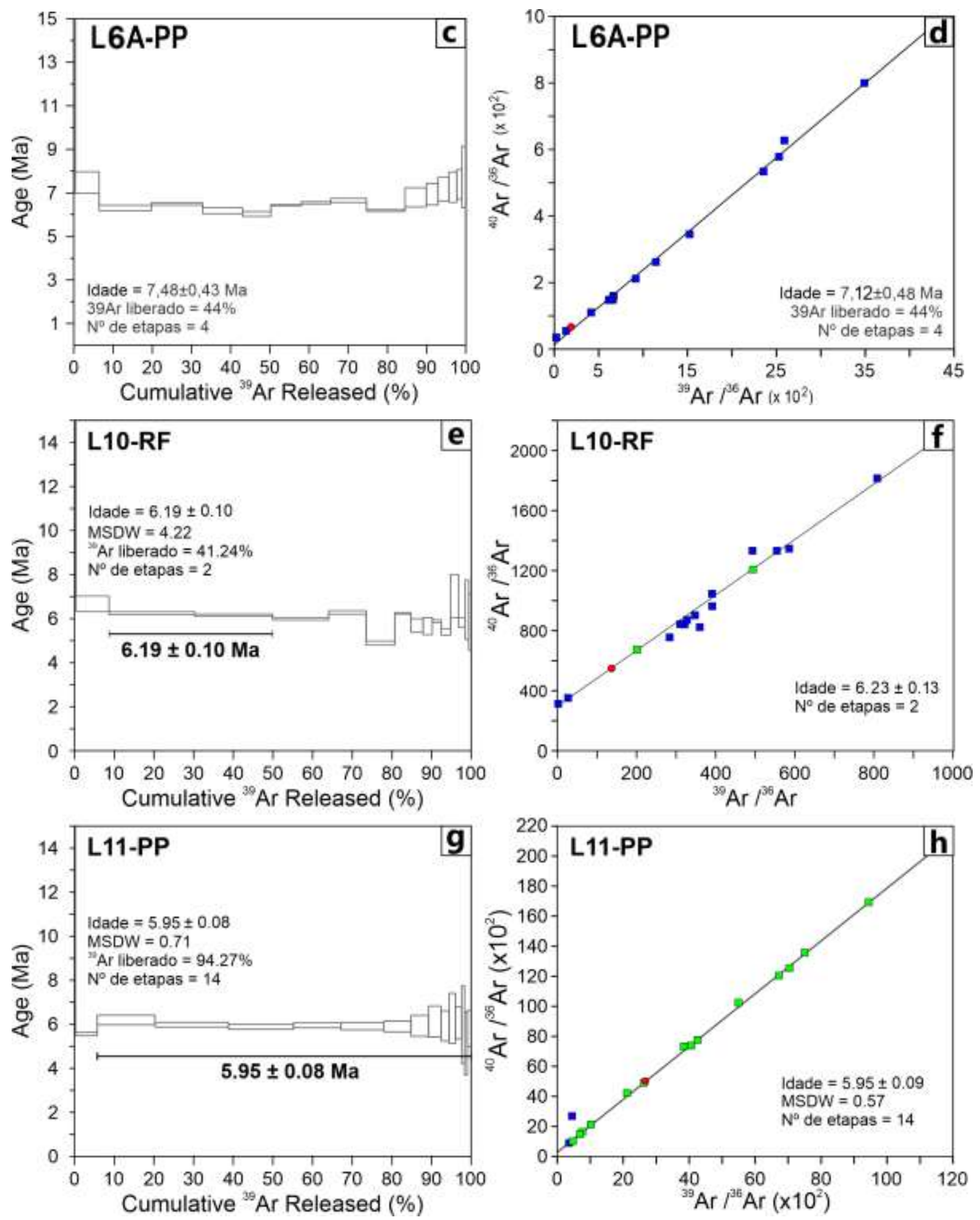

Figura 16: Espectros de aquecimento gradual e isócronas normais, pelo método ${ }^{40} \mathrm{Ar} /{ }^{39} \mathrm{Ar}$.

$\mathrm{Na}$ ilha de São Tomé, apenas um traquito (P12A-IC) coletado no ilhéu das Cabras foi analisado, tendo sido determinada a idade plateau, calculada com $87 \%$ ${ }^{39} \mathrm{Ar}$ liberado em 14,44 $\pm 0,15 \mathrm{Ma}$ (Figura 17a), sendo idêntica à idade isocrônica 
$(14,35 \pm 0,16 \mathrm{Ma}$; Figura 17b) e discretamente mais jovem que a idade de fusão total $(14,81 \pm 0,16 \mathrm{Ma})$.

No entanto, como foi esposto no capítulo de geologia regional, a ilha de São Tomé é subdividida em uma Formação Vulcânica e três Complexos Vulcânicos. O Complexo mais antigo é o de Mizambú com idades compreendidas entre 8 e $6 \mathrm{Ma}$ (Fitton and Dunlop, 1985; Caldeira et al., 2003), aflorando na região centro e sul. O Complexo de Ribeira Afonso possui datações entre 5 e 2,5 Ma (Fitton and Dunlop, 1985; Fitton, 1987; Halliday et al., 1988; Caldeira et al., 2003), com pequena ocorrência na região norte e principalmente na região sudeste e sul. Por fim, o Complexo Vulcânico de São Tomé possui idades inferiores à 1,5 Ma (Fitton and Dunlop, 1985; Halliday et al., 1988; Caldeira and Munhá, 2002; Caldeira et al., 2003), abrangendo a maior parte da região norte e o extremo sul da ilha.
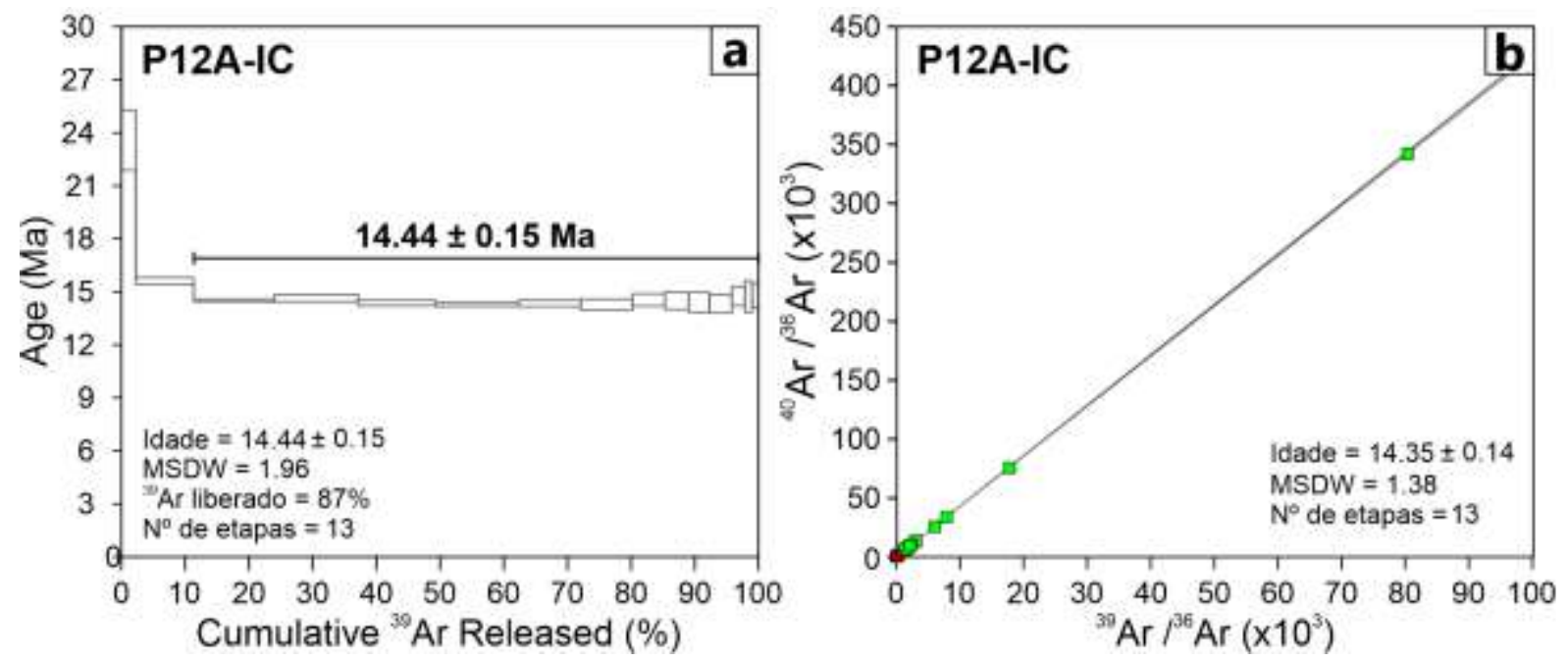

Figura 17: Espectros de aquecimento gradual e isócronas normais, pelo método ${ }^{40} \mathrm{Ar} /{ }^{39} \mathrm{Ar}$.

Grunau et al. (1975) determina a idade máxima de 15,7 \pm 0,8 Ma para a ilha de São Tomé limitada em uma única amostra sem identificar o local de amostragem. Mais tarde Fitton and Dunlop (1985) baseado algumas amostragens e respectivas localizações (Ilhéu das Cabras) indica uma datação de 13,25 \pm 0,45 Ma, que passa a ser utilizada por diversos autores como sendo a idade máxima da ilha. Todavia, neste trabalho é determinada a idade robusta de 14,44 \pm 0,15 Ma para o traquito do Ilhéu das Cabras.

Os resultados geocronológicos obtidos para as amostras da llha do Príncipe, em conformidade com o descrito por Dunlop and Fitton (1979), correspondem às idades das séries de lavas mais jovens, com idades entre 5,9 e 7,7 Ma. 
No caso da ilha de Ano Bom, os resultados geocronológicos obtidos nas amostras AB4-AW e AB7-AB, em 4,89 $\pm 0,13$ Ma e 4,92 \pm 0,12 Ma, respectivamente, referentes ao segundo evento vulcânico descrito do Cornen and Maury (1980), que recobriu boa parte da Ilha, são similares as idades obtidas por Lee et al. (1994), nas mesmas rochas datadas por Piper and Richardson (1972) que havia publicado um valor de 18,4 Ma pelo método K-Ar. Para o traquito (AB3-PF) do Pico del Fuego, que representa o último evento geológico, dentre os três ocorrido na ilha, foi produzida uma idade de 4,58 $\pm 0,08 \mathrm{Ma}$, superior à de 3,9 $\pm 0,2 \mathrm{Ma}$ obtida pelos pesquisadores Cornen and Maury (1980), pelo método K-Ar. Segundo eles este último evento vulcânico foi responsável pelos fluxos de lavas basaníticas ocorridas a norte e sul da ilha. Entretanto, a amostra AB5-MB, que corresponde ao fluxo a sul da ilha, produziu uma idade média ponderada em 5,82 $\pm 0,28 \mathrm{Ma}$. 


\section{CONSIDERAÇÕES FINAIS}

À luz das observações das variações etárias obtidas nas ilhas do Golfo da Guiné, a sul da LVC, os resultados do estudo geocronológico Ar-Ar em conjunto com as demais idades anteriores, denotam um período entre 3 e $6 \mathrm{Ma}$ em que houve coexistência de atividades vulcânicas nas três ilhas.

Os resultados obtidos neste trabalho trouxeram contribuições petrográficas, geoquímicas, isotópicas e geocronológicas das ilhas oceânicas do Golfo da Guiné, apresentando dados inéditos de qualidade analítica satisfatória, que nos levaram a tecer considerações, buscando correlacionar com os trabalhos já existentes, a fim de atingir os objetivos preconizados para esta dissertação.

Foi feita a caracterização petrográfica de uma série de rochas pertencentes às diversas variedades vulcânicas que ocorrem nas llhas de Ano-Bom, São Tomé e Príncipe. Fizeram parte do estudo rochas pertencentes às principais litologias máficas e félsicas das três ilhas, incluindo todas as amostras que tiveram análises químicas, isotópicas e datações Ar-Ar. O trabalho em verdade não traz novidades em relação ao que já estava bem estabelecido no conhecimento das variedades petrográficas existentes, em vários trabalhos anteriores, desde Teixeira (1949), Neiva (1956) e Cornen and Maury (1980) até Halliday et al. (1990), Lee et al. (1994) e Munhá et al. (2007), dentre outros. Por outro lado, permitiu um controle adequado na escolha das amostras submetidas a análises químicas e geocronológicas.

No caso da geoquímica de rochas, houve também confirmação em relação ao que já se conhecia sobre as variedades máficas e félsicas. Estas constituíram duas tendências alcalinas ao longo de séries magmáticas distintas, uma com alto teor de álcalis e a outra com alto teor de sílica, englobando às três ilhas em ambas as séries magmáticas. O comportamento dos elementos maiores, menores e traços, nos diagramas de Harker, também mostrou similaridade de processos envolvendo a evolução desses magmas, onde a cristalização fracionada possivelmente teve um papel preponderante na sua evolução.

Por outro lado, embora exista grande similaridade evolutiva dos magmas das ilhas do Golfo da Guiné, elas podem ser provenientes de fontes distintas, dadas as características isotópicas apresentadas.

Os resultados obtidos nas análises isotópicas de $\mathrm{Sr}, \mathrm{Nd}$ e $\mathrm{Pb}$ confirmaram e melhoraram os dados apresentados por Halliday et al. (1990). Nos diagramas que 
relacionam $\mathrm{Sr}$ com $\mathrm{Nd}$, as rochas das três ilhas são contíguas ao componente mantélico HIMU, com tendência de aproximação ao Atlântico MORB. No caso dos diagramas com isótopos de chumbo constatou-se que a ilha de Príncipe apresenta $\mathrm{Pb}$ mais radiogénico, onde os hawaítos de idades antigas não apresentam assinaturas HIMU, e Ano-Bom é aquela que apresenta $\mathrm{Pb}$ menos radiogénico. São Tomé e Príncipe são caracterizadas pelo componente FOZO, e sobrepõem ao limite de fonteira oceano/continente, enquanto Ano-Bom apresenta similaridade com as Ilhas de Ascension e da Madeira.

Pelas características isotópicas, a hipótese de que os magmas parentais das três ilhas a sul da LVC sejam provenientes de uma mesma fonte não procede, pois rochas de Ano-Bom apresentam assinatura isotópica distinta de outras de São Tomé e Príncipe, com misturas de componentes HIMU e DMM e pouca influência de EM-I.

Todas as idades radiométricas conhecidas dessas ilhas foram consideradas adequadas, apesar dos diferentes métodos verificados, mas reconhece-se que diversas datações podem estar afetadas por perda de argônio por alteração, especialmente quando as rochas apresentam certa quantidade de vidro vulcânico devitrificado.

A Figura 18 é um histograma que reúne todas as idades radiométricas conhecidas para as ilhas do Golfo da Guiné. Verifica-se imediatamente que o vulcanismo registrado nas partes emersas dos três edifícios vulcânicos continuou até tempos recentes, registrando grandes erupções entre 1,35 Ma e 200 mil anos, aproximadamente, nas ilhas de São Tomé e Ano Bom.

Para a llha de São Tomé, com maior número de datações disponíveis, percebe-se que o pulso vulcânico que continua até o Pleistoceno se iniciou há aproximadamente $8 \mathrm{Ma}$ atrás, no final do Mioceno, tendo sido relativamente contínuo. A atividade mais importante parece ter ocorrido entre 6 e 3 Ma e boa parte dos corpos félsicos monolíticos têm idades dentro desse intervalo. O mesmo ocorre para a maioria das rochas expostas em Príncipe e Ano-Bom.

A llha do Príncipe, a mais próxima do continente, possui as rochas mais antigas, uma delas com 30,6 Ma. Além disso, nessa ilha a rocha mais jovem tem 3,5 $\mathrm{Ma}$, não aparecendo rochas com menos de $1 \mathrm{Ma}$. No caso de São Tomé, o traquito da Formação Ilhéu das Cabras tem aproximadamente 14,5 Ma, e algumas lavas do Complexo São Tomé, originadas a partir do Pico de São Tomé, têm idades Pleistocênicas, inferior a $1 \mathrm{Ma}$. Para Ano-Bom, a idade mais antiga registrada foi de 
5,82 Ma em Mabana e as mais novas, originadas pelo último evento vulcânico associado ao Pico del Fuego, com idade também inferior a 1 Ma.

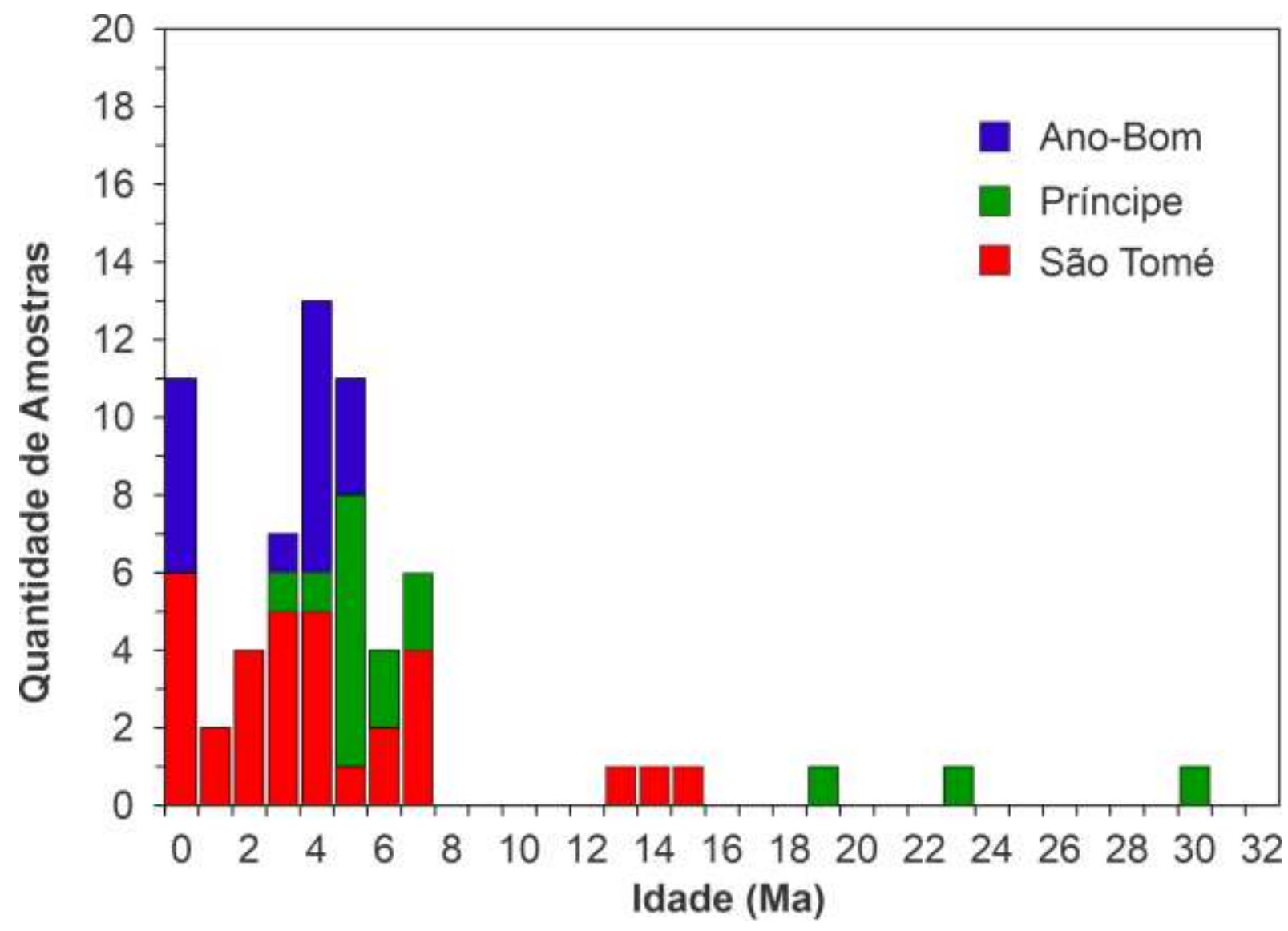

Figura 18: Histograma do vulcanismo das llhas do setor oceânico da Linha Vulcânica dos Camarões.

Conforme indicado no sugundo capítulo deste trabalho, a LVC tem sido interpretada como uma grande zona de cisalhamento formada por ocasião da separação entre América do Sul e África, formando a litosfera oceânica do Atlântico Sul a partir do Cretáceo Inferior, há cerca de 120 Ma (Burke, 2001; Njome and de Wit, 2014; entre outros). Sua continuidade no Brasil seria o lineamento de Pernambuco, como contraparte do lineamento de Adamawa, nos Camarões. A sua extensão na parte continental da África é enorme (Figura 2), e os centros magmáticos identificados (Bambouto, Oku, Mandara e muitos outros) possuem idade desde $70 \mathrm{Ma}$ (Déruelle et al., 1991) até o presente, como é o caso do vulcão ativo do Monte Camarões.

A origem e evolução da LVC tem sido fonte de muitos debates discordantes. A possibilidade de derivação a partir de um hot spot localizado na base do manto tem sido descartada, vista a ausência de progressão etária (figura 1) do vulcanismo 
em quaisquer dos seus setores (Marzoli et al., 2000; Courtillot et al., 2003; entre outros). Adams et al. (2015) compararam vários modelos geodinâmicos. Com base em tomografia sísmica, esses autores chegaram a sugerir algumas possibilidades evolutivas, relacionadas com instabilidades apresentadas pela litosfera continental, mas sem evidências conclusivas.

Em suma, na sua parte continental, a LVC apresenta a permanência de centros magmáticos praticamente estacionários durante muitos milhões de anos. Ela também afeta o domínio litosférico transicional, onde se localiza a ilha de Bioko e o Monte Camarões, bem como a litosfera oceânica pós-jurássica, sobre a qual assentam os edifícios vulcânicos de Ano-Bom, São Tomé e Príncipe. Em vista da coerência de seus produtos magmáticos, situados sobre litosferas distintas, continental, transicional e oceânica, suas fontes são obviamente astenosféricas. Como a hipótese de hot spot está descartada, em vista da falta de um padrão de idades de rochas com continuidade espacial, resta a evidência factual da existência de fontes diferentes, atuando em muitos lugares ao longo da LVC, a partir do Cratáceo até o presente. Como foi indicado no respectivo capítulo, em vista da assinatura isotópica das fontes, próximas do componente mantélico FOZO, com alguma mistura dos componentes HIMU, DMM e possivelmente EM-I, suas profundidades podem ser estimadas em pelo menos $400 \mathrm{Km}$. 


\section{REFERÊNCIAS BIBLIOGRÁFICAS}

Adams, A.N., Wiens, D.A., Nyblade, A.A., Euler, G.G., Shore, P.J., and Tibi, R., 2015, Lithospheric instability and the source of the Cameroon Volcanic Line: Evidence from Rayleigh wave phase velocity tomography: Journal of Geophysical Research: Solid Earth, v. 120, p. 1708-1727, doi:10.1002/2014JB011580.

Aka, F.T., Nagao, K., Kusakabe, M., Sumino, H., Tanyileke, G., Ateba, B., and Hell, J., 2004, Symmetrical Helium isotope distribution on the Cameroon Volcanic Line, West Africa: Chemical Geology, v. 203, p. 205-223, doi:10.1016/j.chemgeo.2003.10.003.

Asaah, A.N.E. et al., 2020, Major/trace elements and $\mathrm{Sr}-\mathrm{Nd}-\mathrm{Pb}$ isotope systematics of lavas from lakes Barombi Mbo and Barombi Koto in the Kumba graben, Cameroon volcanic line: Constraints on petrogenesis: Journal of African Earth Sciences, v. 161, p. 103675, doi:10.1016/j.jafrearsci.2019.103675.

Asaah, A.N.E., Yokoyama, T., Aka, F.T., Usui, T., Wirmvem, M.J., Chako Tchamabe, B., Ohba, T., Tanyileke, G., and Hell, J. V., 2015, A comparative review of petrogenetic processes beneath the Cameroon Volcanic Line: Geochemical constraints: Geoscience Frontiers, v. 6, p. 557-570, doi:10.1016/j.gsf.2014.04.012.

Barfod, D.N., Ballentine, C.J., Halliday, A.N., and Fitton, J.G., 1999, Noble gases in the Cameroon line and the $\mathrm{He}, \mathrm{Ne}$, and $\mathrm{Ar}$ isotopic compositions of high $\mu$ (HIMU) mantle: Journal of Geophysical Research: Solid Earth, v. 104, p. 2950929527, doi:10.1029/1999jb900280.

Bas, M.J.L., Maitre, R.W.L., Streckeisen, A., and Zanettin, B., 1986, A Chemical Classification of Volcanic Rocks Based on the Total Alkali-Silica Diagram: Journal of Petrology, v. 27, p. 745-750, doi:10.1093/petrology/27.3.745.

Browne, S., and Fairhead, J.D., 1983, Gravity study of the Central African Rift system: A model of continental disruption 1. The Ngaoundere and Abu Gabra Rifts: Tectonophysics, v. 94, p. 187-203, doi:10.1016/0040-1951(83)90016-1.

Burke, K., 2001, Origin of the cameroon line of volcano-capped swells: Journal of Geology, v. 109, p. 349-362, doi:10.1086/319977.

Caldeira, R., 2006, Estudo Petrológico e Geoquímico dos xenólitos e das lavas da Ilha de São Tomé (Arquipélago de São Tomé e Príncipe). Tese de Doutorado 
em Geoquímica.: Letras de Ciências da Terra e do Planeta, p. 322.

Caldeira, R., Madeira, J., Munhá, J.M., Afonso, R.S., Mata, J., Tassinari, C.C., and Nascimento, E., 2003, Caracterização das principais unidades vulcanoestratigráficas da ilha de São Tomé, Golfo da Guiné: Ciencias da Terra (UNL), Lisboa, p. 15-18.

Caldeira, R., and Munhá, J.M., 2002, Petrology of ultramafic nodules from São Tomé Island, Cameroon Volcanic Line (oceanic sector): Journal of African Earth Sciences, v. 34, p. 231-246, doi:10.1016/S0899-5362(02)00022-2.

Cornen, G., and Maury, R.C., 1980, Petrology of the volcanic island of Annobon, Gulf of Guinea: Marine Geology, v. 36, p. 253-267, doi:10.1016/00253227(80)90090-0.

Courtillot, V., Davaille, A., Besse, J., and Stock, J., 2003, Three distinct types of hotspots in the Earth's mantle: Earth and Planetary Science Letters, v. 205, p. 295-308, doi:10.1016/S0012-821X(02)01048-8.

DePaolo, D.J., 1981, Nd Isotopic Studies: Some new perspectives on Earth structure and evolution: Eos, Transactions American Geophysical Union, v. 62, p. 137137, doi:10.1029/EO062i014p00137-01.

Déruelle, B. et al., 2000, Éruptions simultanées de basalte alcalin et de hawaiite au mont Cameroun (28 mars-17 avril 1999): Comptes Rendus de l'Academie de Sciences - Serie lla: Sciences de la Terre et des Planetes, v. 331, p. 525-531, doi:10.1016/S1251-8050(00)01454-3.

Déruelle, B., Moreau, C., Nkoumbou, C., Kambou, R., Lissom, J., Njonfang, E., Ghogomu, R.T., and Nono, A., 1991, The Cameroon Line: A Review, in Magmatism in Extensional Structural Settings, Springer Berlin Heidelberg, p. 274-327, doi:10.1007/978-3-642-73966-8_12.

Déruelle, B., Ngounouno, I., and Demaiffe, D., 2007, The "Cameroon Hot Line" $(\mathrm{CHL})$ : A unique example of active alkaline intraplate structure in both oceanic and continental lithospheres: Comptes Rendus - Geoscience, v. 339, p. 589600, doi:10.1016/j.crte.2007.07.007.

Dunlop, H.M., and Fitton, J.G., 1979, A K-Ar and Sr-Isotopic Study of the Volcanic Rocks of the Island of Principe, West Africa-Evidence for Mantle Heterogeneity Beneath the Gulf of Guinea.:

Emery, K., and Uchupi, E., 1984, The Geology of the Atlantic Ocean Springer-Verlag: , p. 925. 
Fitton, J.G., 1983, Active Versus Passive Continental Rifting: Evidence from the West African Rift System, in Elsevier, p. 473-481, doi:10.1016/B978-0-444-421982.50032-8.

Fitton, J.G., 1980, The Benue trough and cameroon line - A migrating rift system in West Africa: Earth and Planetary Science Letters, v. 51, p. 132-138, doi:10.1016/0012-821X(80)90261-7.

Fitton, J.G., 1987, The Cameroon line, West Africa: A comparison between oceanic and continental alkaline volcanism: Geological Society Special Publication, v. 30, p. 273-291, doi:10.1144/GSL.SP.1987.030.01.13.

Fitton, J., and Dunlop, H., 1985, The Cameroon line, West Africa, and its bearing on the origin of oceanic and continental alkali basalt: Earth and Planetary Science Letters, v. 72, p. 23-38, doi:10.1016/0012-821X(85)90114-1.

Fitton, J.G., and Hughes, D.J., 1977, Petrochemistry of the volcanic rocks of the Island of Principe, Gulf of Guinea: Contributions to Mineralogy and Petrology, v. 64, p. 257-272, doi:10.1007/BF00371757.

Freeth, S.J., Kling, G.W., Kusakabe, M., Maley, J., Tchoua, F.M., and Tietze, K., 1990, Conclusions from Lake Nyos disaster [4]: Nature, v. 348, p. 201, doi:10.1038/348201a0.

Fuster Casas, J., 1954, Estudo petrogenetico dos vulcones del Golf de Guinea.: Instituto dos Estudos Africanos, p. 155.

Gèze, B., 1941, Alkaline Rocks and Carbonatites of the World: África: CR Acad. Sci. Paris , 212, p. 498-500.

Gorini, M., and Bryan, G., 1976, The tectonic Fabric of the Equatorial Atlantic and Adjoining Continental Margins: Gulf of Guinea to the Northeastern Brazil: Geodynamics project, Scientific report, v. 48, p. 101-119.

Gountié Dedzo, M., Asaah, A.N.E., Martial Fozing, E., Tchamabé, B.C., Tefogoum Zangmo, G., Dagwai, N., Tchokona Seuwui, D., Kamgang, P., Aka, F.T., and Ohba, T., 2019, Petrology and geochemistry of lavas from Gawar, Minawao and Zamay volcanoes of the northern segment of the Cameroon volcanic line (Central Africa): Constraints on mantle source and geochemical evolution: Journal of African Earth Sciences, v. 153, p. 31-41, doi:10.1016/j.jafrearsci.2019.02.010.

Grunau, H., Lehner, P., Cleintaur, M., and Allenbach, P., 1975, Progresso em geodinâmica. Novas idades radiométricas e dados sísmicos de Fuerteventura 
(Ilhas Canárias), Maio (Ilhas Cabo Verde) e São Tomé (Golfo) da Guiné), em andamento em geodinâmica: Anais do Simpósio Nacional de Geodinâmica. North-Holland Co., Nova: , p. 90-118.

Halliday, A.N., Davidson, J.P., Holden, P., DeWolf, C., Lee, D.-C., and Fitton, J.G., 1990, Trace-element fractionation in plumes and the origin of HIMU mantle beneath the Cameroon line: Nature, v. 347, p. 523-528, doi:10.1038/347523a0.

Halliday, A.N., Dickin, A.P., Fallick, A.E., and Fitton, J.G., 1988, Mantle Dynamics: A $\mathrm{Nd}, \mathrm{Sr}, \mathrm{Pb}$ and $\mathrm{O}$ Isotopic Study of the Cameroon Line Volcanic Chain: Journal of Petrology, v. 29, p. 181-211, doi:10.1093/petrology/29.1.181.

Hamilton, P.J., O'Nions, R.K., Bridgwater, D., and Nutman, A., 1983, Sm-Nd studies of Archaean metasediments and metavolcanics from West Greenland and their implications for the Earth's early history: Earth and Planetary Science Letters, v. 62, p. 263-272, doi:10.1016/0012-821X(83)90089-4.

Hart, S.R., 1984, A large-scale isotope anomaly in the Southern Hemisphere mantle: Nature, v. 309, p. 753-757, doi:10.1038/309753a0.

Jacquemin, H., Sheppard, S.M.F., and Vidal, P., 1982, Isotopic geochemistry (O, Sr, $\mathrm{Pb}$ ) of the Golda Zuelva and Mboutou anorogenic complexes, North Cameroun: mantle origin with evidence for crustal contamination: Earth and Planetary Science Letters, v. 61, p. 97-111, doi:10.1016/0012-821X(82)90042-5.

Janousěk, V., Farrow, C.M., and Erban, V., 2006, Interpretation of Whole-rock Geochemical Data in Igneous Geochemistry: Introducing Geochemical Data Toolkit (GCDkit): Journal of Petrology, v. 47, p. 1255-1259, doi:10.1093/petrology/egl013.

Jones, P.J., Burlison, J.P., and Tye, A., 1991, Conservação dos ecossistemas florestais na República Democrática de São Tomé e Príncipe. Programa para as florestas tropicais.: Livros,.

Kling, G.W., Clark, M.A., Wagner, G.N., Compton, H.R., Humphrey, A.M., Devine, J.D., Evans, W.C., Lockwood, J.P., Tuttle, M.L., and Koenigsberg, E.J., 1987, The 1986 Lake Nyos Gas Disaster in Cameroon, West Africa: Science, v. 236, p. 169-175, doi:10.1126/science.236.4798.169.

Lasserre, B., 1978, Mise au point sur les granitoïdes dits "ultimes" tertiaires du Cameroun: gisement, pétrographie et géochronologie: , p. 143.

Lee, D.C., Halliday, A.N., Fitton, J.G., and Poli, G., 1994, Isotopic variations with distance and time in the volcanic islands of the Cameroon line: evidence for a 
mantle plume origin: Earth and Planetary Science Letters, v. 123, p. 119-138, doi:10.1016/0012-821X(94)90262-3.

Le Maitre, R. W., Bateman, P., Dudek, A., Keller, J., Lameyre, J., Le Bas, M. J., Sabine, P. A., Schmid, R., Sorensen, H., Streckeisen, A., Woolley, A. R. \& Zanettin, B. (1989), A Classification of Igneous Rocks and Glossary of Terms: Recommendations of the International Union of Geological Sciences Subcommission on the Systematics of Igneous Rocks. Oxford: Blackwell Scientific.

Liotard, J.M., Dupuy, C., Dostal, J., and Cornen, G., 1982, Geochemistry of the volcanic island of Annobon, Gulf of Guinea: Chemical Geology, v. 35, p. 115128, doi:10.1016/0009-2541(82)90022-5.

Lopes, J., 2010, Caracterização Geoquímica Isotópica das Rochas Vulcânicas da Ilha de São Tomé.: Trabalho de Formatura. Instituto de Geociências da Universidade de São Paulo, v. 26.

Lopes, R.P., 2002, O vulcanismo do Arquipélago de Fernando de Noronha, PE: química mineral e geoquímica: Tese de Doutorado em Mineralogia e Petrologia. Instituto de Geociências - Universidade de São Paulo, p. 168, doi:10.11606/T.44.2002.tde-17092013-095935.

Lopes, J., Caldeira, R., Cordani, U., and Munhá, J., 2011, Isotope geochemistry of São Tomé Island (Cameroon Volcanic Line): Implications for mantle source components: Geochemical Journal. Goldschmidt Mineralogical Magazine, p. 1355.

Magdaleno, G.B., Petronilho, L.A., Silva, R.A., Ruiz, I.R., Babinski, M., Hollanda, M.H.B.M., and Martins, V.T.S., 2017, Pb-Sr-Nd Isotopic Characterization of USGS Reference Materials by TIMS at CPGeo-USP. II-Workshop of Inorganic Mass Spectrometry.:

Marzoli, A., Piccirillo, E.M., Renne, P.R., Bellieni, G., lacumin, M., Nyobe, J.B., and Tongwa, A.T., 2000, The cameroon volcanic line revisited: Petrogenesis of continental basaltic magmas from lithospheric and asthenospheric mantle sources: Journal of Petrology, v. 41, p. 87-109, doi:10.1093/petrology/41.1.87.

Marzoli, A., Renne, P.R., Piccirillo, E.M., Francesca, C., Bellieni, G., Melfi, A.J., Nyobe, J.B., and N'ni, J., 1999, Silicic magmas from the continental Cameroon Volcanic Line (Oku, Bambouto and Ngaoundere): 40 Ar- 39 Ar dates, petrology, $\mathrm{Sr}-\mathrm{Nd}-\mathrm{O}$ isotopes and their petrogenetic significance: Contributions to 
Mineralogy and Petrology, v. 135, p. 133-150, doi:10.1007/s004100050502.

Meyers, J.B., and Rosendahl, B.R., 1991, Seismic reflection character of the Cameroon volcanic line: Evidence for uplifted oceanic crust: Geology, v. 19, p. 1072, doi:10.1130/0091-7613(1991)019<1072:SRCOTC>2.3.CO;2.

Meyers, J.B., Rosendahl, B.R., Harrison, C.G.A., and Ding, Z.-D., 1998, Deepimaging seismic and gravity results from the offshore Cameroon Volcanic Line, and speculation of African hotlines: Tectonophysics, v. 284, p. 31-63, doi:10.1016/S0040-1951(97)00173-X.

Mitchell-Thomé, R.C., 1970, Geology of the South Atlantic Islands, Borntraeger p. 387.

Moreau, C., Regnoult, J.M., Déruelle, B., and Robineau, B., 1987, A new tectonic model for the Cameroon Line, Central Africa: Tectonophysics, v. 141, p. 317334, doi:10.1016/0040-1951(87)90206-X.

Mori, P., Reeves, S., Correia, C., and Haukka, M., 1999, Resumo Desenvolvimento de Método de FRX por disco de vidro por fusão e comparação com a técnica de pastilha de pó prensado no Instituto de Geociências, Universidade de São Paulo: Revista Brasileira de Geociências, v. 29, p. 441-446, doi:10.25249/03757536.199929441446.

Moundi, A., Ménard, J., Reusser, E., Tchoua, F., and Dietrich, V., 1996, Découverte de basaltes transitionnels dans le secteur continental de la Ligne du Cameroun (Massif du Mbam, Ouest-Cameroun): CR Acad. Sci. Paris, Sor. Ila, v. 332, p. 831-837.

Munhá, J.M., Caldeira, R., Madeira, J., Afonso, R., Mata, J., Nascimento, E., and Paquete, L., 2007, Geologia da ilha de São Tomé - Notícia Explicativa da Carta Geológica. Escala 1: 25 000.: 1-52 p.

Neiva, J.M.C., 1956a, Contribuçao para a geologia e geomorfologia de llha do Principe: Conf. Int. Afric. Ocid., v. 2, p. 157-162.

Neiva, J.M.C., 1956b, Contribuição para estudo geológico e geomorfológico da llha de São Tomé e dos llhéus das Rolas e das Cabras.: v. $6^{\text {a }}$ Sess. C, p. 147-153.

Ngako, V., Njonfang, E., Aka, F.T., Affaton, P., and Nnange, J.M., 2006, The NorthSouth Paleozoic to Quaternary trend of alkaline magmatism from Niger-Nigeria to Cameroon: Complex interaction between hotspots and Precambrian faults: Journal of African Earth Sciences, v. 45, p. 241-256, doi:10.1016/j.jafrearsci.2006.03.003. 
Ngounouno, I., and Deruelle, B., 1997, Donnees nouvelles sur le volcanisme cenozoique du plateau Kapsiki (nord du Cameroun): Comptes Rendus Academie des Sciences, Serie II: Sciences de la Terre et des Planetes, v. 324, p. 285-292.

Njome, M.S., and de Wit, M.J., 2014, The Cameroon Line: Analysis of an intraplate magmatic province transecting both oceanic and continental lithospheres: Constraints, controversies and models: Earth-Science Reviews, v. 139, p. 168194, doi:10.1016/j.earscirev.2014.09.003.

Njonfang, E., Kamgang, P., Ghogomu, R.T., and Tchoua, F.M., 1992, The geochemical characteristics of some plutonic-volcanic complexes along the southern part of the Cameroon line: Journal of African Earth Sciences, v. 14, p. 255-266, doi:10.1016/0899-5362(92)90102-I.

Nkouandou, O.F., and Temdjim, R., 2011, Petrology of spinel Iherzolite xenoliths and host basaltic lava from Ngao Voglar Volcano, Adamawa Massif (Cameroon Volcanic Line, West Africa): Equilibrium conditions and mantle characteristics: Journal of Geosciences, v. 56, p. 375-387, doi:10.3190/jgeosci.108.

Nkouathio, D.G., Kagou Dongmo, A., Bardintzeff, J.M., Wandji, P., Bellon, H., and Pouclet, A., 2008, Evolution of volcanism in graben and horst structures along the Cenozoic Cameroon Line (Africa): Implications for tectonic evolution and mantle source composition: Mineralogy and Petrology, v. 94, p. 287-303, doi:10.1007/s00710-008-0018-1.

Nkouathio, D.G., Ménard, J.J., Wandji, P., and Bardintzeff, J.M., 2002, The Tombel graben (West Cameroon): A recent monogenetic volcanic field of the Cameroon Line: Journal of African Earth Sciences, v. 35, p. 285-300, doi:10.1016/S08995362(02)00031-3.

Nkoumbou, C., Déruelle, B., and Velde, D., 1995, Petrology of Mt Etinde Nephelinite Series: Journal of Petrology, v. 36, p. 373-395, doi:10.1093/PETROLOGY/36.2.373.

Nono, A., Déruelle, B., Demaiffe, D., and Kambou, R., 1994, Tchabal Nganha volcano in Adamawa (Cameroon): petrology of a continental alkaline lava series: Journal of Volcanology and Geothermal Research, v. 60, p. 147-178, doi:10.1016/0377-0273(94)90066-3.

Okomo Atouba, C.L., Chazot, G., Moundi, A., Agranier, A., Bellon, H., Nonnotte, P., Nzenti, J.-P., and Kankeu, B., 2016, Mantle sources beneath the Cameroon 
Volcanic Line: geochemistry and geochronology of the Bamoun plateau mafic rocks: Arabian Journal of Geosciences, v. 9, p. 270, 10.1007 / s12517- 0152285-6, doi:10.1007/s12517-015-2285-6.

Piper, J.D.A., and Richardson, A., 1972, The palaeomagnetism of the Gulf of Guinea volcanic province, West Africa: Geophys. J. R. Astr. Soc., v. 29, p. 147-171.

Pouclet, A., Kagou Dongmo, A., Bardintzeff, J.M., Wandji, P., Chakam Tagheu, P., Nkouathio, D., Bellon, H., and Ruffet, G., 2014, The Mount Manengouba, a complex volcano of the Cameroon Line: Volcanic history, petrological and geochemical features: Journal of African Earth Sciences, v. 97, p. 297-321, doi:10.1016/j.jafrearsci.2014.04.023.

Rankenburg, K., Lassiter, J.C., and Brey, G., 2005, The Role of Continental Crust and Lithospheric Mantle in the Genesis of Cameroon Volcanic Line Lavas: Constraints from Isotopic Variations in Lavas and Megacrysts from the Biu and Jos Plateaux: Journal of Petrology, v. 46, p. 169-190, doi:10.1093/petrology/egh067.

Renne, P.R. et al., 2009, Data reporting norms for 40Ar/39Ar geochronology: Quaternary Geochronology, v. 4, p. 346-352, doi:10.1016/j.quageo.2009.06.005.

Le Roex, A.P., Cliff, R.A., and Adair, B.J.I., 1990, Tristan da Cunha, South Atlantic: Geochemistry and Petrogenesis of a Basanite-Phonolite Lava Series: Journal of Petrology, v. 31, p. 779-812, doi:10.1093/PETROLOGY/31.4.779.

Sato, H., Aramaki, S., Kusakabe, M., Hlrabayashi, J.I., Sano, Y., Nojiri, Y., and Tchoua, F., 1990, Geochemical difference of basalts between polygenetic and monogenetic volcanoes in the central part of the Cameroon volcanic line: Geochemical Journal, v. 24, p. 357-370, doi:10.2343/geochemj.24.357.

Schultze, A., 1913, Die Insel Annobon im Golf von Guinea:

Stracke, A., Hofmann, A.W., and Hart, S.R., 2005, FOZO, HIMU, and the rest of the mantle zoo: Geochemistry, Geophysics, Geosystems, v. 6, doi:10.1029/2004GC000824.

Tamen, J., Nkoumbou, C., Reusser, E., and Tchoua, F., 2015, Petrology and geochemistry of mantle xenoliths from the Kapsiki Plateau (Cameroon Volcanic Line): Implications for lithospheric upwelling: Journal of African Earth Sciences, v. 101, p. 119-134, doi:10.1016/j.jafrearsci.2014.09.008.

Tchuimegnie Ngongang, N.B., Kamgang, P., Chazot, G., Agranier, A., Bellon, H., and 
Nonnotte, P., 2015, Age, geochemical characteristics and petrogenesis of Cenozoic intraplate alkaline volcanic rocks in the Bafang region, West Cameroon: Journal of African Earth Sciences, v. 102, p. 218-232, doi:10.1016/j.jafrearsci.2014.10.011.

Teixeira, C., 1949, Geologia das ilhas de S. Tomé e do Príncipe do território de S. João Baptista de Ajudá: Anais da Junta de Investigações Ultramar 2 (2).

Tiabou, A.F., Temdjim, R., Wandji, P., Bardintzeff, J.M., Che, V.B., Bate Tibang, E.E., Ngwa, C.N., and Mebara, F.X.O., 2019, Baossi-Warack monogenetic volcanoes, Adamawa Plateau, Cameroon: petrography, mineralogy and geochemistry: Acta Geochimica, v. 38, p. 40-67, doi:10.1007/s11631-018-0272-9.

Tyrrell, G., 1934, Notas petrográficas sobre rochas do Golfo da Guiné: Revista Geológica,.

Vasconcelos, P.M., Onoe, A.T., Kawashita, K., Soares, A.J., and Teixeira, W., 2002, 40Ar/39Ar geochronology at the Instituto de Geociências, USP: Instrumentation, analytical procedures, and calibration: Anais da Academia Brasileira de Ciencias, v. 74, p. 297-342, doi:10.1590/S0001-37652002000200008.

Velayos, M., Barberá, P., Cabezas, F.J., Estrella, M.D.E.L.A., Fero, M., and Aedo, C., 2014, Checklist of the Vascular Plants of Annobón (Equatorial Guinea): v. 171, 1-78 p.

Wilson, M., and Guiraud, R., 1992, Magmatism and rifting in Western and Central Africa, from Late Jurassic to Recent times: Tectonophysics, v. 213, p. 203-225, doi:10.1016/0040-1951(92)90259-9.

Yang, W. Bin, Niu, H.C., Shan, Q., Chen, H.Y., Hollings, P., Li, N.B., Yan, S., and Zartman, R.E., 2014, Geochemistry of primary-carbonate bearing K-rich igneous rocks in the Awulale Mountains, western Tianshan: Implications for carbonrecycling in subduction zone: Geochimica et Cosmochimica Acta, v. 143, p. 143-164, doi:10.1016/j.gca.2014.04.033.

Yokoyama, T., Aka, F.T., Kusakabe, M., and Nakamura, E., 2007, Plume-lithosphere interaction beneath Mt. Cameroon volcano, West Africa: Constraints from 238U230Th-226Ra and Sr-Nd-Pb isotope systematics: Geochimica et Cosmochimica Acta, v. 71, p. 1835-1854, doi:10.1016/j.gca.2007.01.010.

Zindler, A., and Hart, S.R., 1986, Chemical Geodynamics 2. Mantle chemical heterogeneity: a matter of scale: Annual Reviews of Earth and Planetary Sciences, v. 14, p. 493-571, doi:10.1146/annurev.ea.14.050186.002425. 
Apêndices 
Tabela 4: Variação percentual de minerais presentes nas rochas da llha de Ano-Bom.

\begin{tabular}{|l|c|c|c|c|c|c|c|c|c|}
\hline Litotipo & Olivina-basalto & Olivina-basalto & Traquito & Basanito & Picro- basalto & Basalto & Basalto & Basalto & Picro-basalto \\
\hline Amostra & AB1-PC & AB2-LP & AB3-PF & AB4-AW & AB5-MB & AB6-PP & AB7-AB & AB8-MA & AB9-PC \\
\hline Olivina & 22 & 25 & ---- & 12 & 20 & 35 & 20 & 15 & 40 \\
\hline Cpx & 25 & 18 & ----- & 40 & 25 & 25 & 25 & 25 & 22 \\
\hline PI & 38 & 40 & ---- & 33 & 30 & 20 & 32 & 43 & 19 \\
\hline Foide & ---- & ---- & 7 & ---- & ---- & ---- & ---- & ---- & ---- \\
\hline K-Felds & --- & --- & 87 & --- & ---- & --- & --- & --- & --- \\
\hline Opaco & 7 & 9 & 3 & 10 & 14 & 7 & 15 & 10 & 10 \\
\hline Vidro & 7 & 7 & ---- & 5 & 10 & 12 & 8 & 7 & 8 \\
\hline Biotita & ---- & ---- & 3 & ---- & ---- & ---- & ---- & ---- & --- \\
\hline Apatita & 1 & 1 & 0 & 0 & 1 & 1 & ---- & ---- & 1 \\
\hline Total & 100 & 100 & 100 & 100 & 100 & 100 & 100 & 100 & 100 \\
\hline
\end{tabular}

Tabela 5: Variação percentual dos minerais presentes nas rochas da llha de São Tomé.

\begin{tabular}{|c|c|c|c|c|c|c|c|c|c|c|c|c|c|}
\hline Litotipo & Basalto & $\begin{array}{l}\text { Olivina } \\
\text { basalto }\end{array}$ & Basalto & Basanito & Basalto & Basanito & Tefrito & Tefrito & $\begin{array}{c}\text { Picro- } \\
\text { basalto }\end{array}$ & Basanito & Basanito & Traquito & Traquito \\
\hline Amostra & P1-Al & P2-AD & P3-PP & P4-CG & P5-DN & P6-PM & P7-SN & P8-PA & P9-DA & P10-PP & P11-RP & P12A-IC & P12B-IC \\
\hline Olivina & 10 & 20 & 25 & 20 & 15 & 25 & 8 & 7 & 10 & 20 & 20 & ---- & ---- \\
\hline Cpx & 15 & 10 & 15 & 20 & 15 & 15 & 22 & 20 & 30 & 20 & 40 & ---- & ---- \\
\hline $\mathrm{PI}$ & 55 & 52 & & 34 & 45 & & 42 & 43 & 39 & 34 & 26 & ---- & ---- \\
\hline Foide & ---- & ---- & ---- & --- & ---- & ---- & $\begin{array}{l}--- \\
\end{array}$ & ---- & ---- & ---- & --- & 4 & 4 \\
\hline K-Felds & ---- & $\begin{array}{l}--- \\
\end{array}$ & ---- & ---- & ---- & ---- & --- & ---- & ---- & ---- & ---- & 93 & 93 \\
\hline Opaco & 17 & 10 & 15 & 10 & 10 & 15 & 15 & 15 & 12 & 10 & 9 & 2 & 2 \\
\hline Clorita & ---- & 3 & ---- & ---- & 2 & ---- & --- & ---- & 1 & ---- & ---- & ---- & ---- \\
\hline Vidro & 3 & 5 & 45 & 15 & 13 & 45 & 13 & 15 & 8 & 15 & 5 & ---- & ---- \\
\hline Biotita & ---- & ---- & ---- & ---- & ---- & ---- & ---- & ---- & ---- & ---- & ---- & 1 & 1 \\
\hline Apatita & ---- & ---- & ---- & 1 & ---- & ---- & ---- & ---- & ---- & 1 & ---- & ---- & ---- \\
\hline Total & 100 & 100 & 100 & 100 & 100 & 100 & 100 & 100 & 100 & 100 & 100 & 100 & 100 \\
\hline
\end{tabular}


Tabela 6: Variação percentual dos minerais presentes nas rochas da llha do Príncipe.

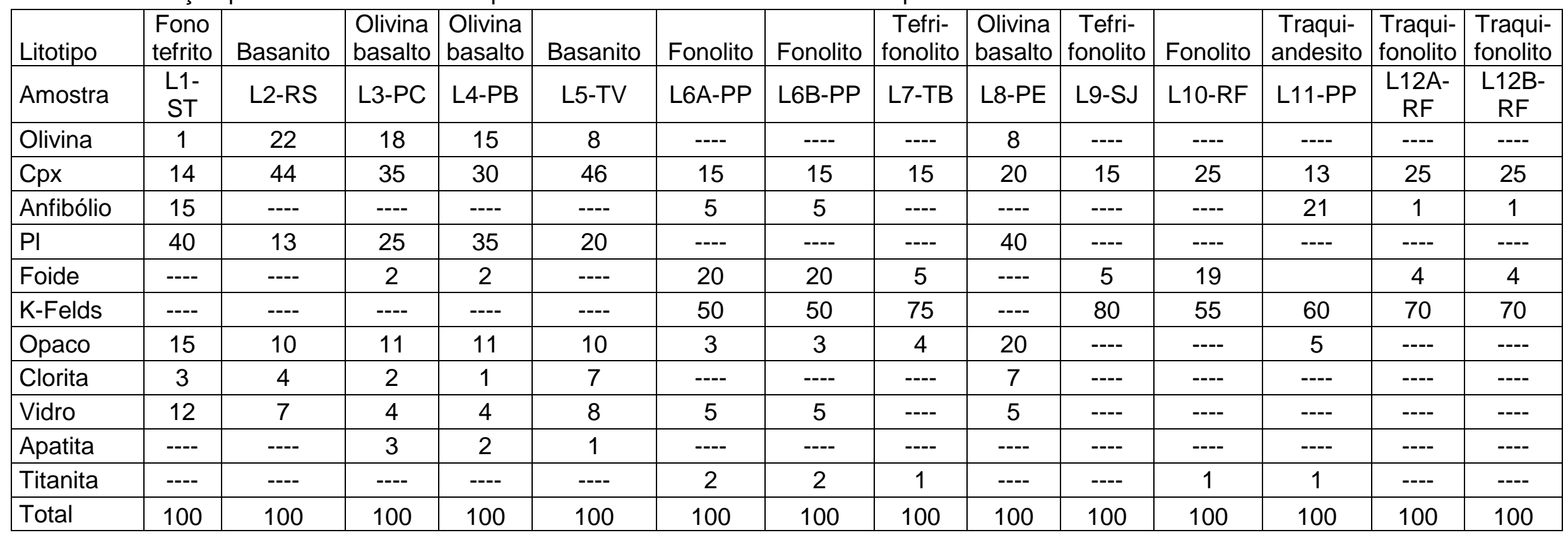




\section{ANEXO 1}

\section{Resultados de análises químicas de Rocha Total por FRX}

Tabela 7:Resultados de análise química por FRX das rochas das Ilhas de Ano-Bom, São Tomé e Príncipe. Óxido em \%peso.

\begin{tabular}{|c|c|c|c|c|c|c|c|c|c|c|c|c|c|c|c|c|c|c|}
\hline \multirow[b]{2}{*}{$\mathrm{SiO} 2$} & \multirow{2}{*}{$\begin{array}{c}\text { AB3-PF } \\
62,51 \\
\end{array}$} & \multirow{2}{*}{$\begin{array}{c}\text { AB4-AW } \\
43,72\end{array}$} & \multirow{2}{*}{\begin{tabular}{|c|} 
AB5-MB \\
45,00 \\
\end{tabular}} & \multirow{2}{*}{$\begin{array}{c}A B 7-A B \\
46,56 \\
\end{array}$} & \multicolumn{2}{|c|}{ AB9-MA } & \multirow{2}{*}{\begin{tabular}{|l} 
L1-ST \\
46,73 \\
\end{tabular}} & \multirow{2}{*}{$\begin{array}{l}\text { L5-TV } \\
42,58 \\
\end{array}$} & \multirow{2}{*}{\begin{tabular}{|c|} 
L6-PPR \\
54,79 \\
\end{tabular}} & \multirow{2}{*}{\begin{tabular}{|c|} 
L10-RF \\
54,43 \\
\end{tabular}} & \multicolumn{2}{|c|}{ L11-PRF } & \multirow{2}{*}{\begin{tabular}{|l|} 
P2-AD \\
45,03 \\
\end{tabular}} & \multirow{2}{*}{\begin{tabular}{|l} 
P4-CG \\
43,20 \\
\end{tabular}} & \multirow{2}{*}{$\begin{array}{c}\text { P9-DA } \\
43,83 \\
\end{array}$} & \multirow{2}{*}{$\begin{array}{c}\mathrm{P} 11-\mathrm{RP} \\
42,31 \\
\end{array}$} & \multicolumn{2}{|c|}{ P12-IC } \\
\hline & & & & & 41,43 & 41,19 & & & & & 53,53 & 53,36 & & & & & 65,71 & 66,23 \\
\hline $\mathrm{TiO} 2$ & 0,374 & 4,388 & 2,770 & 3,969 & 3,125 & 3,104 & 2,393 & 3,535 & 0,383 & 0,501 & 1,128 & 1,133 & 3,160 & 3,262 & 3,352 & 3,057 & 0,309 & 0,313 \\
\hline $\mathrm{Al} 2 \mathrm{O} 3$ & 19,20 & 14,44 & 10,02 & 13,04 & 10,13 & 10,07 & 17,12 & 14,00 & 22,04 & 22,17 & 19,30 & 19,27 & 13,60 & 12,52 & 10,87 & 11,45 & 17,78 & 17,79 \\
\hline $\mathrm{Fe} 2 \mathrm{O} 3$ & 25 & 12,84 & 13,90 & 12,35 & 13,37 & 13,23 & 9,08 & 12,52 & 2,58 & 3,14 & 5,06 & 5,05 & 12,86 & 12,92 & 12,39 & 14,46 & 2,13 & 2,13 \\
\hline $\mathrm{MnO}$ & 0,123 & 0,173 & 0,185 & 0,168 & 0,181 & 0,179 & 0,169 & 0,172 & 0,171 & 0,117 & 0,128 & 0,127 & 0,170 & 0,174 & 0,167 & 0,255 & 0,050 & 0,049 \\
\hline $\mathrm{MgO}$ & 07 & 5,99 & 15,61 & 7,88 & 16,19 & 15,92 & 4,56 & 7,21 & 011 & 0,33 & 1,42 & 1,43 & 9,18 & 10,23 & 11,19 & 12,25 & 0,11 & 0,12 \\
\hline $\mathrm{CaO}$ & 0,50 & 10,33 & 9,51 & 9,18 & 9,98 & 9,90 & 7,72 & 12,5 & 0,99 & 2,16 & 4,49 & 4,49 & 9,89 & 11,17 & 13,21 & 10,75 & 0,45 & 0,45 \\
\hline $\mathrm{Na} 2 \mathrm{O}$ & 5,63 & 2,75 & 1,71 & 2,58 & 1,94 & 1,92 & 5,65 & 2,22 & 11,02 & 9,27 & 6,26 & 6,26 & 2,41 & 3,43 & 1,60 & 2,57 & 6,04 & 6,09 \\
\hline $\mathrm{K} 2 \mathrm{O}$ & & & & & & & & & & & & 4,08 & & & & & 35 & 4,36 \\
\hline $\mathrm{P} 2 \mathrm{O} 5$ & 0,487 & 0,917 & 0,470 & 0,755 & 0,709 & 0,701 & 0,758 & 0,814 & 0,072 & 0,093 & 0,243 & 0,245 & 0,685 & 1,127 & 0,575 & 0,755 & 0,105 & 0,101 \\
\hline Lol & 1,90 & 1,01 & 0,00 & 0,50 & 1,73 & 1,79 & 2,70 & 2,84 & 1,30 & 0,88 & 4,07 & 4,14 & 0,98 & 0,26 & 1,79 & 0,30 & 1,83 & 1,79 \\
\hline Total & 98,85 & 98,94 & 100,10 & 99,19 & 99,66 & 98,86 & 99,45 & 100,31 & 98,82 & 99,12 & 99,72 & 99,59 & 99,06 & 99,64 & 100,04 & 99,15 & 98,86 & 99,42 \\
\hline $\mathrm{K}_{2} \mathrm{O}+\mathrm{Na}_{2} \mathrm{O}$ & 11,80 & 5,24 & 2,63 & 4,85 & 2,87 & 2,87 & 8,50 & 4,25 & 16,77 & 15,58 & 10,82 & 10,83 & 3,57 & 4,81 & 2,72 & 3,60 & 10,70 & 10,71 \\
\hline \multicolumn{19}{|c|}{ Normas CIPW } \\
\hline Quartzo & 6,59 & ----- & ----- & ----- & ----- & ----- & ----- & ----- & ----- & ----- & ----- & ----- & ----- & ---- & ----- & ----- & 12,05 & 12,22 \\
\hline Nefelina & ----- & 5,72 & ----- & ---- & 5,15 & 4,83 & 15,93 & 7,39 & 31,88 & 31,89 & 10,34 & 10,49 & ---- & 11,01 & 2,88 & 7,35 & ----- & ----- \\
\hline Hipersténio & 2,66 & ---- & 2,46 & 0,01 & ---- & ---- & ---- & ---- & ---- & ---- & ---- & ----- & 1,56 & ----- & ---- & ---- & 2,58 & 2,60 \\
\hline Corindon & 3,90 & ---- & ---- & $-\cdots$ & ---- & ---- & ----- & ---- & ---- & ----- & - ---- & - ---- & ---- & ---- & ---- & - --- & 2,57 & 2,48 \\
\hline
\end{tabular}


Tabela 7 (continuação): Rasultados de análise química por FRX das rochas das llhas de Ano-Bom, São Tomé e Príncipe. Traços em ppm.

\begin{tabular}{|c|c|c|c|c|c|c|c|c|c|c|c|c|c|c|c|c|c|c|}
\hline \multirow[b]{2}{*}{$\mathrm{Ba}$} & \multirow{2}{*}{$\frac{A B 3-P F}{825}$} & \multirow{2}{*}{$\begin{array}{c}\text { AB4-AW } \\
812 \\
\end{array}$} & \multirow{2}{*}{\begin{tabular}{|c|} 
AB5-MB \\
328 \\
\end{tabular}} & \multirow{2}{*}{$\frac{A B 7-A B}{602}$} & \multicolumn{2}{|c|}{ AB9-MA } & \multirow{2}{*}{$\begin{array}{c}\text { L1-ST } \\
863 \\
\end{array}$} & \multirow{2}{*}{$\begin{array}{l}\text { L5-TV } \\
563\end{array}$} & \multirow{2}{*}{$\begin{array}{c}\text { L6-PPR } \\
502 \\
\end{array}$} & \multirow{2}{*}{$\begin{array}{c}\text { L10-RF } \\
1090\end{array}$} & \multicolumn{2}{|c|}{ L11-PRF } & \multirow{2}{*}{\begin{tabular}{|l}
$\mathrm{P} 2-\mathrm{AD}$ \\
321
\end{tabular}} & \multirow{2}{*}{\begin{tabular}{|c} 
P4-CG \\
567
\end{tabular}} & \multirow{2}{*}{$\begin{array}{c}\text { P9-DA } \\
382\end{array}$} & \multirow{2}{*}{$\begin{array}{c}\mathrm{P} 11-\mathrm{RP} \\
348 \\
\end{array}$} & \multicolumn{2}{|c|}{ P12-IC } \\
\hline & & & & & 421 & 418 & & & & & 733 & 745 & & & & & 1259 & 1262 \\
\hline $\mathrm{Ce}$ & 112 & 139 & 68 & 109 & 71 & 84 & 154 & 100 & 114 & 98 & 131 & 109 & 83 & 128 & 95 & 72 & 211 & 222 \\
\hline Co & $<6$ & 45 & 91 & 55 & 78 & 79 & 31 & 49 & 13 & 21 & 12 & 13 & 54 & 60 & 58 & 71 & 10 & 10 \\
\hline $\mathrm{Cr}$ & $<13$ & 46 & 814 & 290 & 549 & 550 & 66 & 97 & $<13$ & $<13$ & 13 & 13 & 274 & 286 & 563 & 422 & $<13$ & $<13$ \\
\hline $\mathrm{Cu}$ & $<5$ & 60 & 54 & 48 & 43 & 44 & 29 & 69 & $<5$ & $<5$ & 8 & 8 & 46 & 61 & 90 & 57 & $<5$ & $<5$ \\
\hline $\mathrm{Ga}$ & 30 & 24 & 16 & 21 & 18 & 17 & 23 & 23 & 35 & 25 & 30 & 29 & 20 & 20 & 19 & 18 & 26 & 27 \\
\hline $\mathrm{La}$ & 72 & 62 & $<28$ & 55 & 42 & 39 & 100 & 56 & 77 & 81 & 65 & 82 & 47 & 71 & 41 & 40 & 130 & 127 \\
\hline $\mathrm{Nb}$ & 131 & 66 & 34 & 50 & 52 & 52 & 127 & 69 & 199 & 79 & 115 & 115 & 47 & 74 & 51 & 52 & 134 & 134 \\
\hline $\mathrm{Nd}$ & 25 & 68 & 42 & 56 & 39 & 48 & 62 & 50 & 32 & 30 & 49 & 40 & 55 & 63 & 45 & 41 & 72 & 81 \\
\hline $\mathrm{Ni}$ & $<5$ & 72 & 462 & 189 & 544 & 542 & 53 & 89 & $<5$ & $<5$ & 13 & 13 & 179 & 242 & 204 & 290 & $<5$ & $<5$ \\
\hline $\mathrm{Pb}$ & 16 & $<4$ & 10 & $<4$ & $<4$ & $<4$ & $<4$ & $<4$ & 9 & $<4$ & $<4$ & $<4$ & $<4$ & $<4$ & $<4$ & $<4$ & 12 & 14 \\
\hline $\mathrm{Rb}$ & 167 & 47 & 15 & 39 & 30 & 31 & 47 & 56 & 196 & 137 & 136 & 137 & 19 & 29 & 75 & 21 & 123 & 123 \\
\hline Sc & $<14$ & 28 & 32 & 25 & 28 & 27 & 16 & 28 & $<14$ & $<14$ & $<14$ & $<14$ & 27 & 26 & 42 & 29 & $<14$ & $<14$ \\
\hline $\mathrm{Sr}$ & 176 & 1029 & 455 & 753 & 662 & 661 & 1229 & 964 & 567 & 1032 & 1176 & 1179 & 739 & 1059 & 742 & 725 & 139 & 139 \\
\hline Th & 17 & 9 & 11 & 10 & 10 & 10 & 10 & 9 & 15 & 10 & 12 & 13 & 10 & 10 & 10 & 11 & 17 & 17 \\
\hline$U$ & 13 & 10 & 11 & 10 & 11 & 10 & 10 & 10 & 15 & 11 & 11 & 11 & 11 & 10 & 11 & 11 & 12 & 13 \\
\hline $\mathrm{V}$ & 12 & 304 & 226 & 260 & 256 & 261 & 148 & 272 & 18 & 37 & 70 & 68 & 227 & 226 & 278 & 233 & $<9$ & $<9$ \\
\hline$Y$ & 14 & 35 & 29 & 31 & 27 & 27 & 29 & 29 & 19 & 13 & 19 & 19 & 27 & 31 & 25 & 25 & 36 & 36 \\
\hline $\mathrm{Zn}$ & 64 & 121 & 108 & 110 & 111 & 109 & 108 & 104 & 131 & 83 & 104 & 104 & 108 & 117 & 91 & 112 & 97 & 96 \\
\hline $\mathrm{Zr}$ & 599 & 425 & 227 & 427 & 222 & 222 & 427 & 282 & 1217 & 409 & 669 & 670 & 242 & 289 & 266 & 212 & 487 & 488 \\
\hline$F$ & 121 & 991 & 454 & 948 & 714 & 629 & 953 & 715 & 150 & 212 & 307 & 316 & 706 & 1050 & 672 & 1028 & 50 & $<50$ \\
\hline $\mathrm{Cl}$ & $<500$ & $<500$ & $<500$ & $<500$ & $<500$ & $<500$ & 524 & $<500$ & 1987 & 986 & $<500$ & $<500$ & $<500$ & 537 & $<500$ & $<500$ & $<500$ & $<500$ \\
\hline$S$ & $<550$ & $<550$ & $<550$ & $<550$ & $<550$ & $<550$ & $<550$ & $<550$ & $<550$ & $<550$ & $<550$ & $<550$ & $<550$ & $<550$ & $<550$ & $<550$ & $<550$ & $<550$ \\
\hline
\end{tabular}


ANEXOS 2

E

ANEXO 3 
Tabela 8a: Dados isotópicos ( $\mathrm{Sr}$ e Nd) das llhas de Ano-Bom, São Tomé e Príncipe.

\begin{tabular}{|c|c|c|c|c|c|c|c|}
\hline Amostras & Material & ${ }^{87} \mathrm{Sr} /{ }^{86} \mathrm{Sr}$ & erro (2s) & ${ }^{143} \mathrm{Nd} /{ }^{144} \mathrm{Nd}$ & erro (2s) & $\mathbf{e}_{\mathrm{Nd}(0)}$ & Ref \\
\hline ST96-22 & Basanito & 0,703418 & 0,000027 & 0,512923 & 0,00009 & 5,6 & 1 \\
\hline ST97-47 & Basanito & 0,703352 & 0,000021 & 0,512833 & 0,00008 & 3,8 & 1 \\
\hline ST97-108 & Basanito & 0,703132 & 0,000034 & 0,512870 & 0,00009 & 4,5 & 1 \\
\hline ST98-10 & Tefrifonolito & 0,703411 & 0,000045 & 0,512816 & 0,00007 & 3,5 & 1 \\
\hline ST98-25 & Tefrifonolito & 0,704106 & 0,000041 & 0,512830 & 0,00009 & 3,7 & 1 \\
\hline ST98-38 & Tefrifonolito & 0,703967 & 0,000040 & 0,512758 & 0,00009 & 3,4 & 1 \\
\hline ST98-52 & Tefrifonolito & 0,703452 & 0,000030 & 0,512812 & 0,00003 & 2,3 & 1 \\
\hline ST99-7 & Basalto & 0,703046 & 0,000031 & 0,512916 & 0,00010 & 5,4 & 1 \\
\hline ST99-9 & Basanito & 0,703286 & 0,000031 & 0,512865 & 0,00004 & 4,4 & 1 \\
\hline ST99-19 & Basanito & 0,703346 & 0,000059 & 0,512920 & 0,00009 & 5,5 & 1 \\
\hline ST99-22 & Basanito & 0,703400 & 0,000012 & 0,512820 & 0,00011 & 3,6 & 1 \\
\hline ST-CVM-I & Basanito & 0,704089 & 0,000059 & 0,512799 & 0,00008 & 3,2 & 1 \\
\hline ST-CVST-IV & Basalto & 0,703053 & 0,000019 & 0,512924 & 0,00006 & 5,6 & 1 \\
\hline ST-FVIC-V & Traquito & 0,703643 & 0,000056 & 0,512850 & 0,00012 & 4,1 & 1 \\
\hline ST-CVRA-VI & Basanito & 0,703377 & 0,000014 & 0,512840 & 0,00009 & 4,0 & 1 \\
\hline AN4 & Basanito & 0,703630 & 0,000010 & 0,512854 & 0,00007 & 4,3 & 2 \\
\hline AN7 & Basalto & 0,703730 & 0,000010 & 0,512874 & 0,00006 & 4,7 & 2 \\
\hline AN7BM & Basanito & 0,703350 & 0,000010 & 0,512929 & 0,00009 & 5,7 & 2 \\
\hline AN8 & Basalto & 0,703520 & 0,000010 & 0,512931 & 0,00009 & 5,8 & 2 \\
\hline AN10 & basanito & 0,703240 & 0,000010 & 0,512944 & 0,00006 & 6,1 & 2 \\
\hline AN11 & Basalto & 0,703370 & 0,000020 & 0,512905 & 0,00013 & 5,3 & 2 \\
\hline AN12 & Basanito & 0,703340 & 0,000010 & 0,512936 & 0,00005 & 5,8 & 2 \\
\hline AN13 & Basanito & 0,703280 & 0,000010 & 0,512972 & 0,00006 & 6,5 & 2 \\
\hline AN14 & Basanito & 0,703430 & 0,000010 & 0,512930 & 0,00007 & 5,7 & 2 \\
\hline AN17 & Basanito & 0,703400 & 0,000010 & 0,512922 & 0,00009 & 5,5 & 2 \\
\hline AN19 & Basanito & 0,703370 & 0,000020 & 0,512913 & 0,00006 & 5,4 & 2 \\
\hline AN20 & Basanito & 0,703400 & 0,000010 & 0,512922 & 0,00008 & 5,5 & 2 \\
\hline P6 & Hawaiíto & 0,70317 & 0,000010 & 0,512853 & 0,00007 & 4,7 & 2 \\
\hline P12 & Tristanito & 0,70322 & 0,000010 & 0,512922 & 0,00001 & 5,5 & 3 \\
\hline $\mathrm{P} 13$ & Tristanito & 0,70301 & 0,000020 & 0,512865 & 0,00020 & 4,4 & 3 \\
\hline P21 & Hawaiíto & 0,70311 & 0,000010 & 0,512853 & 0,00007 & 4,7 & 2 \\
\hline P25 & Hawaiíto & 0,70297 & 0,000010 & 0,512849 & 0,00008 & 4,6 & 2 \\
\hline $\mathrm{P} 26$ & Hawaiíto & 070312 & 0,000010 & 0,512868 & 0,00007 & 5,0 & 2 \\
\hline P39 & Fonolito & 0,70378 & 0,000020 & 0,512940 & 0,00008 & 5,9 & 3 \\
\hline $\mathrm{P} 40$ & Fonolito & 0,70328 & 0,000010 & 0,512906 & 0,00008 & 5,2 & 3 \\
\hline P41 & Traquifonolito & 0,70300 & 0,000010 & 0,512930 & 0,00007 & 5,7 & 3 \\
\hline ST54 & Traquifonolito & 0,70332 & 0,000020 & 0,512853 & 0,00030 & 4,2 & 3 \\
\hline ST93 & Basalto & 0,70320 & 0,000010 & 0,512889 & 0,00010 & 4,9 & 3 \\
\hline ST72 & Basanito & 0,70318 & 0,000010 & 0,512919 & 0,00006 & 5,5 & 3 \\
\hline ST43 & Traquito & 0,70316 & 0,000010 & 0,512937 & 0,00007 & 5,8 & 3 \\
\hline ST106 & Alkali-basalto & 0,70315 & 0,000020 & 0,512899 & 0,00021 & 5,1 & 3 \\
\hline ST100 & Traquibasalto & 0,70312 & 0,000010 & 0,512925 & 0,00009 & 5,6 & 3 \\
\hline ST73 & Tefrito & 0,70307 & 0,000010 & 0,512953 & 0,00007 & 6,1 & 3 \\
\hline ST110 & Tefrifonolito & 0,70299 & 0,000010 & 0,512980 & 0,00010 & 6,7 & 3 \\
\hline ST109 & Basanito & 0,70299 & 0,000020 & 0,512998 & 0,00007 & 7,0 & 3 \\
\hline
\end{tabular}


Tabela 9a: Dados isotópicos (Pb) das Ilhas de Ano-Bom, São Tomé e Príncipe.

\begin{tabular}{|c|c|c|c|c|c|c|}
\hline Localização & Amostra & Material & ${ }^{206} \mathrm{~Pb} /{ }^{204} \mathrm{~Pb}$ & ${ }^{207} \mathrm{~Pb} /{ }^{204} \mathrm{~Pb}$ & ${ }^{208} \mathrm{~Pb} /{ }^{204} \mathrm{~Pb}$ & Ref \\
\hline São Tomé & ST54 & Traquifonolito & 20,128 & 15,674 & 39,87 & 2 \\
\hline São Tomé & ST93 & Basalto & 20,064 & 15,666 & 39,79 & 2 \\
\hline São Tomé & ST72 & Basanito & 19,997 & 15,683 & 39,72 & 2 \\
\hline São Tomé & ST43 & Traquito & 20,060 & 15,658 & 39,69 & 2 \\
\hline São Tomé & ST106 & Alkali-basalto & 19,944 & 15,653 & 39,59 & 2 \\
\hline São Tomé & ST100 & Traquibasalto & 20,014 & 15,659 & 39,68 & 2 \\
\hline São Tomé & ST73 & Tefrito & 20,074 & 15,720 & 39,80 & 2 \\
\hline São Tomé & ST110 & Tefrito Fonolítico & 20,124 & 15,691 & 39,84 & 2 \\
\hline São Tomé & ST109 & Basanito & 19,954 & 15,676 & 39,57 & 2 \\
\hline Príncipe & $\mathrm{P} 12$ & Tristanito & 20,226 & 15,680 & 39,86 & 2 \\
\hline Príncipe & P13 & Tristanito & 20,237 & 15,701 & 39,93 & 2 \\
\hline Príncipe & P39 & Fonolito & 20,259 & 15,677 & 39,80 & 2 \\
\hline Príncipe & $\mathrm{P} 40$ & \begin{tabular}{|l|} 
Fonolito \\
\end{tabular} & 20,285 & 15,673 & 39,82 & 2 \\
\hline Príncipe & $\mathrm{P} 41$ & Traquifonolito & 20,190 & 15,684 & 39,82 & 2 \\
\hline Ano-Bom & AN3 & Basalto & 18,935 & 15,597 & 38,78 & 3 \\
\hline Ano-Bom & AN4 & Basanito & 18,957 & 15,584 & 38,89 & 3 \\
\hline Ano-Bom & AN7 & Basalto & 19,079 & 15,594 & 39,07 & 3 \\
\hline Ano-Bom & AN7BM & Basanito & 18,901 & 15,611 & 38,84 & 3 \\
\hline Ano-Bom & AN8 & Basalto & 19,257 & 15,639 & 39,24 & 3 \\
\hline Ano-Bom & AN10 & basanito & 18,846 & 15,607 & 38,67 & 3 \\
\hline Ano-Bom & AN11 & Basalto & 19,198 & 15,643 & 39,16 & 3 \\
\hline Ano-Bom & AN12 & Basanito & 18,983 & 15,610 & 38,87 & 3 \\
\hline Ano-Bom & AN13 & Basanito & 19,049 & 15,580 & 38,80 & 3 \\
\hline Ano-Bom & AN14 & Basanito & 18,941 & 15,626 & 38,99 & 3 \\
\hline Ano-Bom & AN17 & Basanito & 18,971 & 15,616 & 38,95 & 3 \\
\hline Ano-Bom & AN19 & Basanito & 18,890 & 15,629 & 38,93 & 3 \\
\hline Ano-Bom & AN20 & Basanito & 18,909 & 15,629 & 38,96 & 3 \\
\hline Ano-Bom & P6 & Hawaiíto & 19,786 & 15,672 & 39,63 & 3 \\
\hline Ano-Bom & $\mathrm{P} 21$ & Hawaiíto & 19,734 & 15,672 & 39,58 & 3 \\
\hline Ano-Bom & $\mathrm{P} 25$ & Hawaiíto & 19,547 & 15,668 & 39,39 & 3 \\
\hline Ano-Bom & P26 & Hawaiíto & 19,658 & 15,657 & 39,44 & 3 \\
\hline
\end{tabular}

(1) Lopes, 2010; (2) Lee et al., 1994; (3) Halliday et al., 1990. ST= São Tomé; AN= Ano-Bom; $\mathrm{P}=$ Príncipe. 